(C) 2021 by the Arizona Board of Regents on behalf of the University of Arizona. This is an Open Access article, distributed under the terms of the Creative Commons Attribution-NonCommercial-NoDerivatives licence (http://creativecommons.org/licenses/by-nc-nd/4.0/), which permits non-commercial re-use, distribution, and reproduction in any medium, provided the original work is unaltered and is properly cited. The written permission of Cambridge University Press must be obtained for commercial re-use or in order to create a derivative work.

\title{
CULTURE, PERIOD OR STYLE? RECONSIDERATION OF EARLY AND MIDDLE COPPER AGE CHRONOLOGY OF THE GREAT HUNGARIAN PLAIN
}

\author{
Zsuzsanna Siklósi ${ }^{1 *(1)} \cdot$ Márton Szilágyi² ${ }^{2}$ \\ ${ }^{1}$ Institute of Archaeological Sciences, Eötvös Loránd University, H-1088 Budapest, Múzeum körút 4/B, Hungary \\ ${ }^{2}$ Gemeinde Oberschneiding, Pfarrer-Handwercher-Platz 4, 94363 Oberschneiding, Lower Bavaria, Germany; and \\ Institute of Archaeological Sciences, Eötvös Loránd University, H-1088 Budapest, Múzeum körút 4/B, Hungary
}

\begin{abstract}
The main goal of our research project was to date the Early and Middle Copper Age (4500/4450-3800 cal $\mathrm{BC})$ of the Great Hungarian Plain more precisely. In our project, we took samples for accelerator mass spectrometry (AMS) dating from both settlement features and burials, and the data were analyzed using Bayesian modeling. We examined the Early and Middle Copper Age finds of the Great Hungarian Plain on several levels (site, microregional, and regional levels) using a bottom-up approach. The AMS measurements were supplemented by statistics-based pottery analysis in order to make our understanding of the relationship between the Tiszapolgár and Bodrogkeresztúr cultures more detailed. As a result, we can see a significant, 130 (68.2\%) 230 years overlap between the two types of find assemblages, which contradicts to the earlier accepted chronological sequences created by the traditional culture-historical approach. According to the stylistic analyzes, the two ceramic styles are not clearly distinguishable.
\end{abstract}

KEYWORDS: AMS dating, Bayesian modeling, Copper Age.

\section{INTRODUCTION}

As a result of the research of Ida Bognár-Kutzián, Nándor Kalicz and Pál Patay it seemed that the cultural and chronological frameworks of the Early and Middle Copper Age (henceforth ECA and MCA) of the Great Hungarian Plain (henceforth GHP) were well outlined by the end of the 20th century (Bognár-Kutzián 1963, 1972; Patay 1974; Kalicz 1988a, 1988b). After the abandonment of the Late Neolithic (henceforward LN) tells, a new find material, known as the Tiszapolgár culture appeared around $4500 \mathrm{cal} \mathrm{BC}$. At the same time, formal cemeteries, copper tools, and a more dispersed settlement pattern of smaller, hamlet-like settlements also appeared on the GHP (Bognár-Kutzián 1963, 1972; Parkinson 2006). This new era lasted until ca. 4000 cal BC and was described as the ECA. Thus, it was not only a cultural but also a chronological unit.

Researchers considered the following Bodrogkeresztúr culture as a cultural and chronological successor of the Tiszapolgár culture, which, in addition to changes in pottery shapes and decoration, was associated with the appearance of gold ornaments and heavy copper artifacts in a large number (Patay 1974; Kalicz 1992: 10; Raczky 1999). The MCA period lasted from 4000 cal BC until 3600 cal BC and was also described as a cultural and chronological unit. It was divided into two phases and due to the changes of the pottery style the later phase of the Bodrogkeresztúr culture was called as Bodrogkeresztúr B and later the autonomous Hunyadihalom culture was identified in the second half of the MCA period (Bognár-Kutzián 1969; Kalicz 1979-1980).

This traditional culture-historical approach was based on the existence of homogeneous spatial and chronological units and cultures, and a unilinear evolution was presumed throughout the

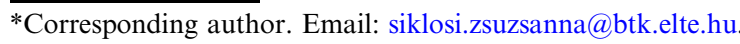


whole GHP (Kalicz 1988a, 1988b). In addition to the vertical stratigraphy at Székely-Zöldtelek (Kalicz 1958), the basis of this cultural and chronological system was the 154 burials excavated in the cemetery of Tiszapolgár-Basatanya (Bognár-Kutzián 1963).

The groundbreaking publications of E. Neustupný and C. Renfrew on the absolute dating of prehistoric Europe and the independence of the Southeastern European Copper Age outlined the chronology of the Balkans, the Carpathian Basin, and Central Europe based on the few available calibrated radiocarbon $\left({ }^{14} \mathrm{C}\right)$ dates. In their works, the dating of one site or a single ${ }^{14} \mathrm{C}$ date was generalized to an entire archaeological culture or region (Neustupný 1968, 1969; Renfrew 1969).

Because of its significance, the Basatanya cemetery was one of the first among the prehistoric ${ }^{14} \mathrm{C}$-dated sites in Hungary. These early conventional measurements, with a standard error of 140-190 years, provided the basis for dating the ECA and MCA of the whole GHP. Thus, these two phases lasted for 800-1000 years (Bognár-Kutzián 1985: 296, Table 2; Bognár-Kutzián and Csongor 1987: 134-138; Benkő et al. 1989; Bankoff and Winter 1990). As another result, the span of the cemetery's use itself was supposed to be approximately 900 years (Forenbaher 1993: 237, 246, Figure 3, Table 1; Hertelendi et al. 1995; Sofaer Derevenski 1997, 2000; Chapman 2000: 76). Summarizing the transformations between the LN and ECA on the GHP R. Yerkes et al. (2009) confirmed this idea based on earlier conventional ${ }^{14} \mathrm{C}$ measurements.

The results of large-scale rescue excavations in the 2000s revealed the fact that there are severe problems with these frameworks. The cemetery excavated in Hajdúböszörmény-Ficsori-tódúlő provided typical Tiszapolgár-style pottery according to the published finds, and according to ${ }^{14} \mathrm{C}$ data, it can be dated from $4350(68.2 \%) 4265 \mathrm{cal} \mathrm{BC}$ to $4310(68.2 \%)$ 4215 cal BC (Kovács and Váczi 2007). Shortly afterwards, another Copper Age (henceforward CA) cemetery was excavated at Rákóczifalva-Bivaly-tó site $1 / \mathrm{c}^{1}$ and due to a large number of milk jugs, gold and copper ornaments, and heavy copper tools it was culturally assigned to the Bodrogkeresztúr culture. However, the accelerator mass spectrometry (AMS) measurements of the cemetery provided surprisingly early dates between 4350 (68.2\%) $4270 \mathrm{cal} \mathrm{BC}$ and 4150 (68.2\%) $4015 \mathrm{cal} \mathrm{BC}$ (Csányi et al. 2010). As a consequence, two cemeteries that should be sequential in time according to the traditional typochronological and cultural frameworks might be contemporaneous based on ${ }^{14} \mathrm{C}$ measurements.

A further methodological problem in dating and interpreting this period is that previous measurements were made on material collected from formal cemeteries in almost all cases. Thus, we have very little information on how settlements and settlement burials related to burials within a cemetery; how pottery styles used in different site contexts related to the styles that appeared in the special, ritual context of formal cemeteries.

\footnotetext{
${ }^{1}$ Csányi et al. (2010); Raczky and Siklósi (2013) referred the site as Rákóczifalva-Bagi föld 1/c and we referred it as Rákóczifalva-Bivaly-tó $1 / \mathrm{c}$ in our earlier paper presenting the results of archaeometallurgical analyses (Siklósi and Szilágyi 2019). The official site names are Rákóczifalva-Bagi-föld, Bivaly-tó site 1/a and site 1/c, furthermore Rákóczifalva-Bagi-földek site 8 and 8/a. These names were confusingly used in the former publications (see also Zoffmann 2011, 2015; Szilágyi 2015); therefore, we suggest to clarify and use the abbreviated names. As the sites $1 / \mathrm{a}$ and $1 / \mathrm{c}$ are very close to each other, we suggest to use Rákóczifalva-Bivaly-tó $1 / \mathrm{a}$ and $1 / \mathrm{c}$ respectively. Site 8 is located farther SW of these sites, we suggest to differentiate it using the name of Rákóczifalva-Bagi föld site 8 . Sites 8 and 8 a refer to the identical site, they refer to two adjacent surfaces of the excavation.
} 
Therefore, for better understanding the chronological position of the mentioned pottery styles, we took new AMS samples from the Basatanya cemetery and the Hunyadihalom graves excavated in Tiszalúc-Sarkad. These were supplemented with earlier AMS dates known from other ECA and MCA sites (Raczky and Siklósi 2013). These data led to surprising results. In the case of the Basatanya cemetery, our hypothesis that the surprisingly long use span of the cemetery (and therefore the dating of the whole period under discussion) is caused merely by the conventional ${ }^{14} \mathrm{C}$ measurements with an unacceptably high standard error was confirmed.

Based on our new AMS measurements, generally with a 30-year standard error, the span was significantly reduced to $300(68.2 \%) 510$ years. The burials from Tiszalúc-Sarkad were proven to be also significantly earlier than expected. Comparing the new AMS measurements with the previously published ones, we found that while the dating of the Tiszapolgár assemblages corresponded with the expectations, the dates of the Bodrogkeresztúr and Hunyadihalom assemblages were much earlier than they were supposed to be. Thus, a partial contemporaneity of phenomena that was thought to be sequential must be presumed (Raczky and Siklósi 2013). All these facts made a complex reevaluation of the period and a review of the traditional typochronological system necessary based on new information sources.

Therefore, in our research project using Bayesian modeling of AMS measurements, we tested whether the former typochronological dating based on the changes of pottery styles could be maintained. This was completed by a statistics-based stylistic analysis of the ceramics and compared it with the traditional typochronological categories. Were the Tiszapolgár and Bodrogkeresztúr styles in use contemporaneously or is it just a virtual phenomenon representing a methodological problem? Can the GHP be treated as a homogeneous analytical unit? Are there spatial differences in the use of ceramic styles within a time horizon? Is the method of extrapolating the ${ }^{14} \mathrm{C}$ dating of a site to a whole region still acceptable? Finally, after answering these questions, is it possible to keep handling the Tiszapolgár and Bodrogkeresztúr cultures as homogeneous, analytical units and consider them to be stylistic units?

\section{METHODS AND RESULTS}

\section{The Notion of Tiszapolgár and Bodrogkeresztúr Cultures}

During the complete evaluation of the Basatanya cemetery, Ida Bognár-Kutzián separated it into two periods: ECA (Tiszapolgár culture) and MCA (Bodrogkeresztúr culture), and she also defined transitional graves that bore the characteristics of both periods. She developed a meticulous pottery typology for both periods which is still the basis for distinguishing Tiszapolgár and Bodrogkeresztúr potteries. She considered the pedestalled bowls, cups and jars as the most important pottery types of the Tiszapolgár period while milk jugs, flowerpot-shaped vessels, bowls, and cups were most commonly placed into Bodrogkeresztúr graves. The most characteristic decoration in the ECA is made of impressed lentil-shaped dots organized into rows or geometric patterns. The MCA decoration is characterized by incised geometrical motifs, net pattern, sometimes combined with dots. According to Bognár-Kutzián, the latter is not unknown even in the ECA (Bognár-Kutzián 1963: 236-305, 1972). 
Patay analyzed further the Bodrogkeresztúr pottery (Patay 1974, 2008). He noted that classic milk jugs appeared already in the Tiszapolgár-Bodrogkeresztúr transitional period, or perhaps even earlier, and can be derived from ECA jug types. He considered the conical and biconical bowls typical for the ECA, while the hemispherical shapes are typical for the MCA. According to him, the two-handled mugs (depas amphikypellon) can exclusively be dated to the MCA; they appeared from the transitional phase (Patay 2008: 34-38).

The typochronology of copper artifacts provided an even more unstable ground for dating than pottery. Bognár-Kutzián tried to fit copper axes into a chronological system (Bognár-Kutzián 1972: 197-201). Patay assumed that the spread of certain types of flat axes and hammer-axes could be dated to the Tiszapolgár culture, and these were constantly in use until the end of the MCA. He dated axe-adzes to the MCA, considering them to be the leading type of CA metallurgy (Patay 1984). Kalicz also emphasized the difference in quantity and quality between copper horizons 2 (ECA) and 3 (MCA) alongside some changes in shapes (Kalicz 1992: 10).

Based on the typology of gold pendants and the accompanying ceramics, only the gold pendants found in the Tibava and the Velké Raškovce cemeteries in eastern Slovakia are considered to be ECA ones (Šiška 1964; Vizdal 1977). All other gold ornament was dated to the transitional phase or to the MCA. Except for the Hencida gold treasure, the custom of gold depositing is dated to the MCA (Raczky 1999; Csedreki et al. 2010; Virág 2010).

Researchers using the traditional typochronological approach emphasized the distinction between the two cultures, although in many cases they encountered difficulties in differentiating them even on fieldwork. We can see the similarity between the two cultures regarding certain cultural phenomena (e.g., the funeral rite) which was explained by the "genetic" relationship between them. The difficulties of differentiation are indicated by the problem of transitional graves found in many sites. Bognár-Kutzián and Patay explained this phenomenon differently. Already during the detailed evaluation of the Basatanya cemetery, Bognár-Kutzián encountered the phenomenon that some graves contained characteristic finds of both Tiszapolgár and Bodrogkeresztúr cultures. She regarded them as transitional graves, emphasizing that these assemblages did not represent the Tiszapolgár-Bodrogkeresztúr transformation. In her opinion, the Bodrogkeresztúr culture appeared in the cemetery in its classic, developed phase; thus, the two types of assemblages are not an organic continuation of each other within the site (Bognár-Kutzián 1963: 523).

In her book of the Tiszapolgár culture, Bognár-Kutzián distinguished territorial groups and two chronological phases within the culture. The importance of the Tiszaug(-Kisrétpart) group is significant regarding the transition, as this group appeared in the Middle Tisza region only in the later chronological phase. Its characteristic incised decorations would represent the connecting link to the Bodrogkeresztúr culture (Bognár-Kutzián 1972: 190). In contrast to this, based on the find materials of a settlement discovered in Tiszaföldvár Cs. Siklódi presumed that the Kisrétpart group appeared already in the early period of the Tiszapolgár culture, not only in its late phase (Siklódi 1982-1983: 17).

In his many works on the typochronology of the Bodrogkeresztúr culture, Patay analyzed the assemblages of the Tiszapolgár to Bodrogkeresztúr transitional period. The transitional potteries bear the stylistic characteristics of both periods (most recently see Patay 2008). On the basis of the vessel types, we are again and again confronted with the fact that there are only differences in proportions of pottery types between the two archaeological cultures, 
and no sharp boundary can be drawn between them (Patay 2008: 39). This situation perfectly illustrates the difficulties of using the concept of archaeological culture and the traditional culture-historical approach.

The transitional period from the LN to the ECA was circumscribed based on both Slovakian (Šiška 1968) and Hungarian (Kalicz and Raczky 1984) sites. The so-called Prototiszapolgár phase was defined by unpainted pottery with plastic decoration from the youngest layers of Neolithic tells. Pál Raczky and his colleagues suggested that the use of this term should be discarded because the Prototiszapolgár pottery style cannot be clearly outlined in space and time (Raczky et al. 2014). In our study, we do not discuss this period in detail, as this would require a series of new AMS measurements and a new project to date precisely the cessation of the LN tells on the GHP. Most of these sites are dated only with old, conventional measurements made on charcoal samples from uncertain archaeological contexts (cf. Kalicz and Raczky 1987; Yerkes et al. 2009).

Since the purpose of our study is to investigate the chronological relationship between the two find materials which are distinguished primarily by pottery styles, we consistently use the terms Tiszapolgár and Bodrogkeresztúr style in the following. Labeling the find material is based on the traditional typochronological system described above, in order to show how traditional categories relate to each other chronologically.

\section{New AMS Measurements and Bayesian Modeling}

Twenty-seven AMS ${ }^{14} \mathrm{C}$ measurements were made for clarifying the chronological issues, selected specifically to answer spatial and stylistic questions (Figure 1). Our goal was to date different types of sites (cemetery, single grave, settlement) within a narrower geographical unit. Samples were taken from two microregions of the GHP from different sites characterized by Tiszapolgár and Bodrogkeresztúr styles. These were supplemented by dating of further sites that, due to their finds, played a crucial role in the assessment of the ECA and MCA of the GHP.

The AMS measurements were made on disarticulated animal bones from settlement features or articulated human bone samples from burials in the Poznan Radiocarbon Laboratory, in the Vienna Environmental Research Accelerator and in the Oxford Radiocarbon Accelerator Unit. The radiocarbon dates were calibrated with the IntCal13 curve (Reimer et al. 2013) using the OxCal 4.3.2 software (Bronk Ramsey 2009a, 2017). ${ }^{2}$ In the following, dates are rounded up to 5 years, and we always use $1 \sigma$ dates during our analysis.

The ${ }^{14} \mathrm{C}$ data were refined by Bayesian modeling, which can make generation-level dating possible in an ideal situation (Bayliss 2009; Bayliss et al. 2007, 2011). Compared to the 400-500 years' periods formerly used for the ECA and MCA, this would be a much more accurate method. The use of Bayesian modeling allows us to develop our dating model by considering archaeological prior information. The critical point is what we consider and accept as reliable prior information. Therefore, Bayesian models are interpretative constructions that are continually changing and are always influenced by the variety of evidence we incorporate into the model (Buck et al. 1996).

\footnotetext{
${ }^{2}$ This article was submitted in September 2019, prior to the publication of the IntCal20 calibration curve in August
} 2020 . 


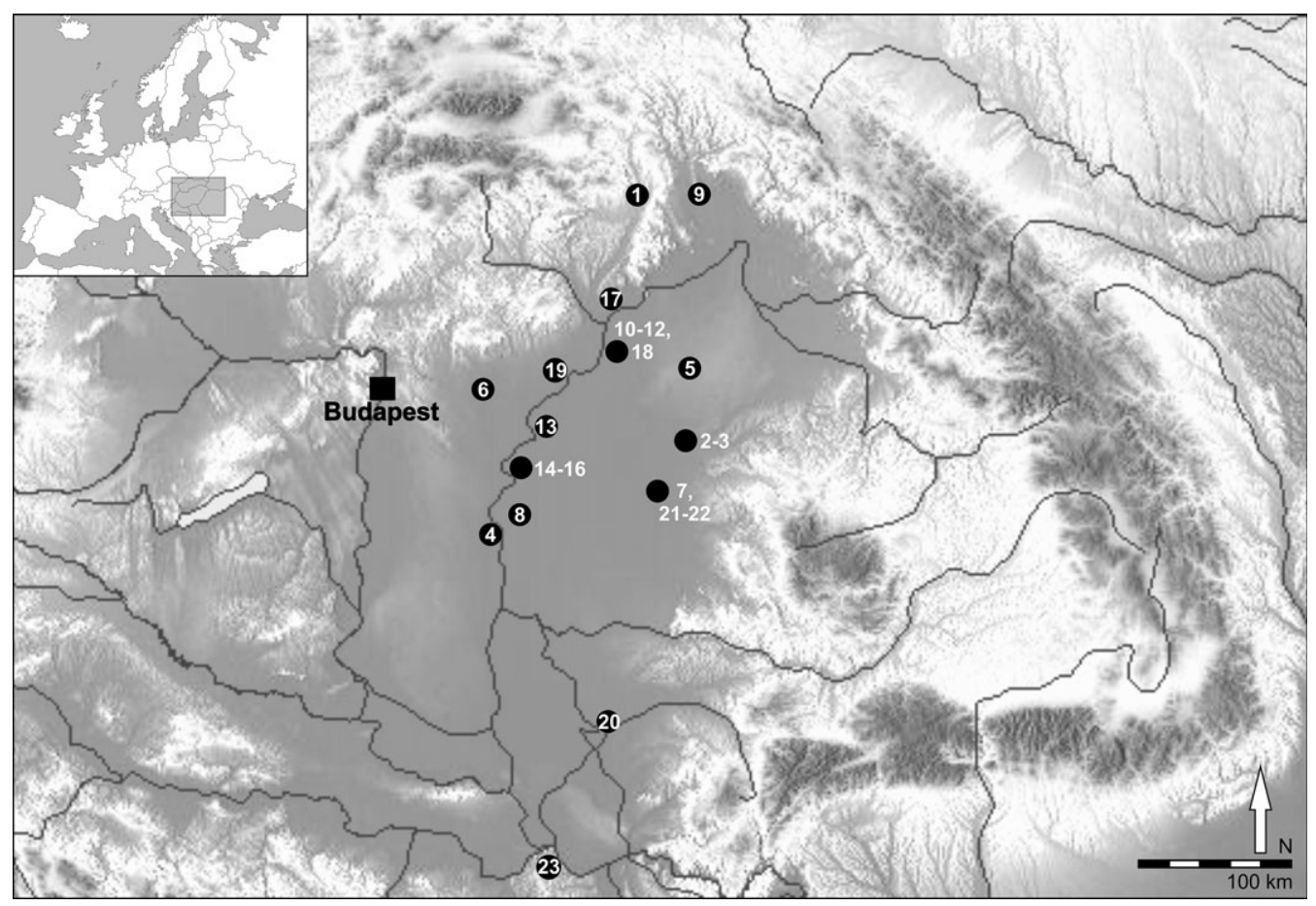

Figure 1 Map of the sites discussed in the text. 1. Barca Baloty, 2. Berettyóújfalu-Berettyólapos-Sertéshízlalda, 3. Berettyóújfalu-Szilhalom, 4. Csongrád-Kettőshalom, 5. Hajdúböszörmény-Ficsori-tó, 6. Jászberény-Borsóhalom, 7. Körösladány-Bikeri, 8. Kunszentmárton-Pusztaistvánháza, 9. Malé Raškovce, 10. Polgár-Királyér-part site 1, 11. Polgár-Nagy-Kasziba, 12. Polgár-Bacsókert, 13. Pusztataskony-Ledence, 14. Rákóczifalva-Bagi föld site 8, 15. Rákóczifalva-Bivaly-tó site 1/a, 16. Rákóczifalva-Bivaly-tó site 1/c, 17. Tiszalúc-Sarkad, 18. TiszapolgárBasatanya, 19. Tiszavalk-Tetes, 20. Uivar, 21. Vésztő-Bikeri, 22. Vésztő-Mágor, 23. Vinča-Belo Brdo.

Strictly speaking, disarticulated animal bones from settlement features provide generally terminus post-quem-or in special cases terminus ad-quem-dates for the infill of a pit and date only indirectly the use of that feature. In these cases, we do not know the elapsed time between the killing of the animal and the disposal of the bone into the pit, but it can provide a sound basis for dating the activity in the settlement.

We did not have the opportunity to perform stable isotopic measurements on the anthropological material we investigated, but from published data (Giblin and Yerkes 2016) it is unlikely that a significant freshwater reservoir effect should be expected.

Validating of models, we did not include misfit or offset measurements, and we used agreement indices in each model in order to see how stable the model is (Bronk Ramsey 2009b).

Furthermore, we performed a statistics-based unified stylistic analysis of the pottery material which pointed out the problems arising from the traditional typochronological approach (Szilágyi 2015). One of the problems of the Bognár-Kutzián typology (due to the focus of the research) is that it is mainly based on the material of cemeteries. The settlement studies and excavations in the last two or three decades showed that in many cases the typology built on pottery from mortuary context does not correspond well with the material of the settlements. On the one hand, there is a practical reason for this since the fragmentation of 
settlement pottery often prevents us from defining vessel shapes precisely. However, it also became clear to us that the pottery sets of the settlements are frequently considerably different from that of the cemeteries, and this cannot be explained with taphonomical reasons. On the other hand, the ceramic material of the cemeteries is a consciously selected set of vessels in a ritual context that is not necessarily identical with the pottery set of a household.

\section{Local Chronologies in Selected Microregions on the Great Hungarian Plain}

In our bottom-up approach, we first created Bayesian models at the site level. We took stratigraphic information into account at each site (Appendix 1).

\section{Polgár Microregion}

The Polgár microregion is one of the well-studied areas of the GHP due to the rescue excavations before the M3 motorway constructions and field surveys performed during several decades. After the cessation of the two or three LN complex tell settlements (Polgár-Csőszhalom, Polgár-Bosnyákdomb, and probably Polgár-Kígyós-domb Raczky et al. 2014: 323, Figure 3; Raczky 2018) the number of ECA and MCA sites considerably grew in this region similar to the Körös region (Bognár-Kutzián 1972; Parkinson 2006).

Different types of sites could be detected in these periods: formal cemeteries-Polgár-Bacsókert (Patay 1959), Tiszapolgár-Basatanya (Bognár-Kutzián 1963), Polgár-Nagy-Kasziba (?) (Raczky et al. 1997; Solnay 2018), Polgár-Horti legelő (unpublished, discovered during our field surveys)—settlements, e.g. Görbeháza-Nagy-kapros-dúlő, Polgár-Cibó-hát, PolgárKirályér-part (Raczky et al. 2014; Szilágyi 2015: 130-141), small grave groups on settlements-Polgár-Királyér-part (Szilágyi 2015: 130-141), and a single ritual wellPolgár-Kengyel-köz (Hajdú 2007: 164-169). We chose samples for AMS measurements to represent different types of sites, and both Tiszapolgár and Bodrogkeresztúr styles.

\section{Polgár-Bacsókert}

After CA finds were discovered southeast of Polgár during sand mining, Patay excavated an $8-12 \times 21-\mathrm{m}$ sondage in 1954. Altogether, 14 graves were uncovered that were probably part of a larger cemetery. The Bodrogkeresztúr site has been destroyed since (Patay 1959: 141). The circumstances of the excavation and the state of the anthropological material in the museums severely limited our opportunities for sample selection. Although these conditions were far from ideal, we still believe that due to its geographic location $(4 \mathrm{~km}$ north of TiszapolgárBasatanya) and its find material, the site can provide valuable information at the microregional level regarding the dating of the period and the use of adjacent sites. We could sample two graves, Grave 3 (female) and Grave 4 (male), located close to each other (Table 1). Since the 14 graves were likely to be part of a larger cemetery similar to Basatanya, we can only precautiously estimate the beginning $(4280(68.2 \%) 3970 \mathrm{cal} \mathrm{BC})$, the end $(4020(68.2 \%) 3685 \mathrm{cal} \mathrm{BC})$ and the span $(0(68.2 \%) 190$ years $)$ of the cemetery's use (Table 2).

\section{Polgár-Királyér-part}

An area of 1.5 hectares of an 11-hectares multi-period site was uncovered on the banks of the Selypes creek (or Király creek) before the construction of the M3 motorway (Hajdú and Nagy 1999: 144-146). Nine CA graves and 13 CA settlement features were discovered in the southwestern part of the excavation area. Six graves were found in a narrow area, five of 
Table 1 New AMS radiocarbon dates measured in this project from ECA and MCA sites and their archaeological context. $\delta^{13} \mathrm{C}$ values of the Poznan Radiocarbon Laboratory cannot be used for palaeoecological reconstructions because of the method of sample preparation.

\begin{tabular}{|c|c|c|c|c|c|c|c|c|c|c|}
\hline Lab. no. & Site & Period & Feature & Material & $\begin{array}{l}{ }^{14} \mathrm{C} \text { age } \\
(\mathrm{BP})\end{array}$ & $\begin{array}{l}\delta^{13} \mathrm{C}(\%) \\
(1 \sigma)\end{array}$ & $\begin{array}{l}\text { cal BC } \\
(68.2 \%)\end{array}$ & $\begin{array}{l}\text { cal BC } \\
(95.5 \%)\end{array}$ & $\begin{array}{l}\text { Archaeological } \\
\text { context, grave goods }\end{array}$ & References \\
\hline Poz-50885 & $\begin{array}{l}\text { Berettyóújfalu- } \\
\text { Berettyólapos- } \\
\text { Sertéshízlalda }\end{array}$ & ECA & Feature $5 / 5$ & $\begin{array}{l}\text { Small ruminant } \\
\text { phalanx prox. } \\
\text { Ant./post. }\end{array}$ & $5360 \pm 40$ & $-22.9 \pm 0.6$ & $4330-4070$ & $4330-4050$ & $\begin{array}{l}\text { Large, deep, round } \\
\text { pit (Tiszapolgár- } \\
\text { style pottery, } \\
\text { daub, animal } \\
\text { bones, shells) }\end{array}$ & Unpublished \\
\hline Poz-50884 & $\begin{array}{l}\text { Berettyóújfalu- } \\
\text { Berettyólapos- } \\
\text { Sertéshízlalda }\end{array}$ & ECA & Feature $4 / 4$ & $\begin{array}{l}\text { Bos primigenius } \\
\text { femur diaph. } \\
\text { Frg.? }\end{array}$ & $5110 \pm 40$ & $-25.4 \pm 0.1$ & $\begin{array}{l}\text { Does not } \\
\text { contain } \\
\text { enough } \\
\text { collagen }\end{array}$ & & $\begin{array}{l}\text { Large, deep, round } \\
\text { pit (Tiszapolgár- } \\
\text { style pottery, } \\
\text { chipped stones, } \\
\text { animal bones) }\end{array}$ & Unpublished \\
\hline Poz-50897 & $\begin{array}{l}\text { Jászberény- } \\
\text { Borsóhalom }\end{array}$ & MCA & Grave 17 & $\begin{array}{l}\text { Homo sapiens, } \\
\text { costa }\end{array}$ & $5270 \pm 40$ & $-16.6 \pm 0.3$ & $4230-3995$ & $4235-3985$ & $\begin{array}{l}2 \text { Bodrogkeresztúr- } \\
\text { style vessels, flint } \\
\text { blade }\end{array}$ & $\begin{array}{l}\text { Csalog 1961; } \\
\text { Raczky } \\
\text { 1988: 33, } 30 . \\
\text { fig. 1-3; } \\
\text { Zoffmann } \\
1980\end{array}$ \\
\hline Poz-50898 & $\begin{array}{l}\text { Kunszentmárton- } \\
\text { Pusztaistvánháza }\end{array}$ & MCA & Grave 15 & Homo sapiens & $5460 \pm 50$ & $-16.4 \pm 0.2$ & $4355-4260$ & $4450-4175$ & $\begin{array}{l}\text { Adultus male, E-W } \\
\text { oriented, lying on } \\
\text { the right side } \\
\text { crouched position, } \\
\text { long flint blade, } 5 \\
\text { (Tiszapolgár- } \\
\text { Bodrogkeresztúr) } \\
\text { vessels }\end{array}$ & $\begin{array}{l}\text { Hillebrand } \\
\text { 1929: 22-23, } \\
\text { Pl. II; } \\
\text { Zoffmann } \\
\text { 1980 }\end{array}$ \\
\hline Poz-50899 & $\begin{array}{l}\text { Kunszentmárton- } \\
\text { Pusztaistvánháza }\end{array}$ & MCA & Grave 29 & $\begin{array}{l}\text { Homo sapiens, } \\
\text { fibula }\end{array}$ & $5300 \pm 40$ & $-16.3 \pm 0.2$ & $4230-4050$ & $4255-3995$ & $\begin{array}{l}\text { E-W oriented, lying } \\
\text { on the left side in } \\
\text { crouched position, } \\
4 \text { Bodrogkeresztúr- } \\
\text { style vessels }\end{array}$ & $\begin{array}{l}\text { Hillebrand } \\
\text { 1929: 26, Pl. } \\
\text { V; Zoffmann } \\
1980\end{array}$ \\
\hline
\end{tabular}


Table 1 (Continued)

\begin{tabular}{|c|c|c|c|c|c|c|c|c|c|c|}
\hline Lab. no. & Site & Period & Feature & Material & $\begin{array}{l}{ }^{14} \mathrm{C} \text { age } \\
(\mathrm{BP})\end{array}$ & $\begin{array}{l}\delta^{13} \mathrm{C}(\%) \\
(1 \sigma)\end{array}$ & $\begin{array}{l}\text { cal BC } \\
(68.2 \%)\end{array}$ & $\begin{array}{l}\text { cal BC } \\
(95.5 \%)\end{array}$ & $\begin{array}{l}\text { Archaeological } \\
\text { context, grave goods }\end{array}$ & References \\
\hline Poz-50892 & Polgár-Bacsókert & MCA & Grave 4 & $\begin{array}{l}\text { Homo sapiens, } \\
\text { cranium }\end{array}$ & $5240 \pm 40$ & $-18.5 \pm 0.8$ & $4225-3975$ & $4230-3965$ & $\begin{array}{l}\text { Adultus-maturus } \\
\text { male, E-W } \\
\text { oriented, lying on } \\
\text { the right side, long } \\
\text { flint blade, } \\
\text { fragment of a } \\
\text { pedestalled bowl, } \\
\text { copper awl }\end{array}$ & $\begin{array}{l}\text { Patay 1959: } \\
\text { 142, Pl. I.1-2. }\end{array}$ \\
\hline Poz-50891 & Polgár-Bacsókert & MCA & Grave 3 & $\begin{array}{l}\text { Homo sapiens, } \\
\text { cranium }\end{array}$ & $5130 \pm 40$ & $-21.9 \pm 0.7$ & $3985-3810$ & $4040-3795$ & $\begin{array}{l}\text { Adultus female, SE- } \\
\text { NW oriented, } \\
\text { lying on the left } \\
\text { side, copper ring, } \\
\text { obsidian nucleus, } \\
\text { vessels }\end{array}$ & $\begin{array}{l}\text { Patay 1959: } \\
\text { 142, Pl. I.6. }\end{array}$ \\
\hline Poz-50887 & $\begin{array}{l}\text { Polgár-Királyér- } \\
\text { part site } 1\end{array}$ & ECA & F181/235 & $\begin{array}{l}\text { Large ungulate } \\
\text { vertebra frg.? }\end{array}$ & $6060 \pm 40$ & $-19.9 \pm 0.3$ & $5030-4900$ & $5200-4840$ & $\begin{array}{l}\text { Amorph pit, } \\
\text { Tiszapolgár-style } \\
\text { pottery }\end{array}$ & $\begin{array}{l}\text { Szilágyi 2015: } \\
\quad 133\end{array}$ \\
\hline Poz-50890 & $\begin{array}{l}\text { Polgár-Királyér- } \\
\text { part site } 1\end{array}$ & ECA & F108/115 & Homo sapiens, ulna & $5380 \pm 40$ & $-22.5 \pm 0.8$ & $4330-4170$ & $4335-4055$ & $\begin{array}{l}\text { Grave, wild boar } \\
\text { mandible, } 4 \\
\text { Tiszapolgár-style } \\
\text { vessels }\end{array}$ & $\begin{array}{l}\text { Szilágyi 2015: } \\
\quad 132\end{array}$ \\
\hline Poz-50886 & $\begin{array}{l}\text { Polgár-Királyér- } \\
\text { part site } 1\end{array}$ & ECA & F141/148 & $\begin{array}{l}\text { Juv. Sus scrofa, } \\
\text { calcaneus dex. }\end{array}$ & $5340 \pm 40$ & $-23.7 \pm 0.4$ & $4255-4065$ & $4325-4045$ & $\begin{array}{l}\text { Round pit, } \\
\text { Tiszapolgár-style } \\
\text { pottery }\end{array}$ & $\begin{array}{l}\text { Szilágyi 2015: } \\
\quad 133\end{array}$ \\
\hline Poz-50888 & $\begin{array}{l}\text { Polgár-Királyér- } \\
\text { part site } 1\end{array}$ & ECA & F112/119 & $\begin{array}{l}\text { Homo sapiens, } \\
\text { costa frg., } \\
\text { phalanx }\end{array}$ & $5330 \pm 40$ & $-24 \pm 0.4$ & $4240-4060$ & $4320-4045$ & $\begin{array}{l}\text { Grave, one adult } \\
\text { (extended) and two } \\
\text { children } \\
\text { (crouched), } 2 \\
\text { Tiszapolgár style } \\
\text { vessels }\end{array}$ & $\begin{array}{l}\text { Szilágyi 2015: } \\
\quad 132\end{array}$ \\
\hline
\end{tabular}

(Continued) 
Table 1 (Continued)

\begin{tabular}{|c|c|c|c|c|c|c|c|c|c|c|}
\hline Lab. no. & Site & Period & Feature & Material & $\begin{array}{l}{ }^{14} \mathrm{C} \text { age } \\
(\mathrm{BP})\end{array}$ & $\begin{array}{l}\delta^{13} \mathrm{C}(\%) \\
(1 \sigma)\end{array}$ & $\begin{array}{l}\text { cal BC } \\
(68.2 \%)\end{array}$ & $\begin{array}{l}\text { cal BC } \\
(95.5 \%)\end{array}$ & $\begin{array}{l}\text { Archaeological } \\
\text { context, grave goods }\end{array}$ & References \\
\hline Poz-50894 & $\begin{array}{l}\text { Polgár-Nagy- } \\
\text { Kasziba }\end{array}$ & ECA & F38/S40 & $\begin{array}{l}\text { Homo sapiens, } \\
\text { fibula }\end{array}$ & $5600 \pm 35$ & $-20.6 \pm 0.3$ & $4460-4365$ & $4500-4355$ & $\begin{array}{l}\text { 54-58-year-old } \\
\text { female, NW-SE, } \\
\text { extended position, } \\
\text { belt consisting of } \\
125 \text { limestone } \\
\text { beads, } 13 \\
\text { Tiszapolgár-style } \\
\text { vessels, red deer } \\
\text { and cattle bones }\end{array}$ & $\begin{array}{l}\text { Raczky et al. } \\
\text { 1997; } \\
\text { Zoffmann } \\
\text { 2004: 86; } \\
\text { Solnay 2018: } \\
\text { 184-186 }\end{array}$ \\
\hline Poz-50895 & $\begin{array}{l}\text { Polgár-Nagy- } \\
\text { Kasziba }\end{array}$ & ECA & F39/S41 & $\begin{array}{l}\text { Homo sapiens, } \\
\text { fibula }\end{array}$ & $5470 \pm 40$ & $-21.7 \pm 0.4$ & $4355-4265$ & $4445-4240$ & $\begin{array}{l}\text { 53-59-year-old male, } \\
\text { W-E, extended, } \\
\text { right side, } 9 \\
\text { vessels, a domestic } \\
\text { pig and a swine } \\
\text { mandible, } 43 \\
\text { limestone and a } \\
\text { copper beads, } \\
\text { polished stone } \\
\text { chisel, } 5 \text { chipped } \\
\text { stone, red deer } \\
\text { antler, wild boar } \\
\text { tusk, pig, red deer } \\
\text { and cattle bones }\end{array}$ & $\begin{array}{l}\text { Raczky et al. } \\
\text { 1997; } \\
\text { Zoffmann } \\
\text { 2004: 86; } \\
\text { Solnay 2018: } \\
\text { 186-188 }\end{array}$ \\
\hline Poz-50896 & $\begin{array}{l}\text { Polgár-Nagy- } \\
\text { Kasziba }\end{array}$ & ECA & $\mathrm{F} 14 / 16$ & Homo sapiens & $5420 \pm 40$ & $-19.6 \pm 0.7$ & $4335-4255$ & $4355-4080$ & $\begin{array}{l}\text { 5-6-year-old child, } \\
\text { extended, W-E, } \\
\text { copper bracelet, } \\
\text { vessel, red deer's } \\
\text { bones }\end{array}$ & $\begin{array}{l}\text { Zoffmann } \\
\text { 2004: 86; } \\
\text { Solnay 2018: } \\
183\end{array}$ \\
\hline Poz-50908 & $\begin{array}{l}\text { Rákóczifalva-Bagi- } \\
\text { föld 1/a }\end{array}$ & ECA & F920/1372 & $\begin{array}{l}\text { Bos primigenius } \\
\text { femur diaph. } \\
\text { Frg. }\end{array}$ & $5285 \pm 30$ & $-21.9 \pm 0.7$ & $4230-4040$ & $4240-3990$ & $\begin{array}{l}\text { Amorph pit } \\
\text { (Tiszapolgár-style } \\
\text { pottery, animal } \\
\text { bones, shell) }\end{array}$ & $\begin{array}{l}\text { Szilágyi 2015: } \\
\quad 145\end{array}$ \\
\hline
\end{tabular}


Table 1 (Continued)

\begin{tabular}{|c|c|c|c|c|c|c|c|c|c|c|}
\hline Lab. no. & Site & Period & Feature & Material & $\begin{array}{l}{ }^{14} \mathrm{C} \text { age } \\
(\mathrm{BP})\end{array}$ & $\begin{array}{l}\delta^{13} \mathrm{C}(\%) \\
(1 \sigma)\end{array}$ & $\begin{array}{l}\text { cal BC } \\
(68.2 \%)\end{array}$ & $\begin{array}{l}\text { cal BC } \\
(95.5 \%)\end{array}$ & $\begin{array}{l}\text { Archaeological } \\
\text { context, grave goods }\end{array}$ & References \\
\hline Poz-50907 & $\begin{array}{l}\text { Rákóczifalva-Bagi- } \\
\text { föld } 1 / a\end{array}$ & ECA & F438/499 & $\begin{array}{l}\text { Sus scofa, scapula } \\
\text { dex. }\end{array}$ & $5150 \pm 50$ & $-20 \pm 0.4$ & $4040-3810$ & $4050-3790$ & $\begin{array}{l}\text { Round pit } \\
\text { (Tiszapolgár-style } \\
\text { pottery, animal } \\
\text { bones, shells) }\end{array}$ & $\begin{array}{l}\text { Szilágyi 2015: } \\
\quad 143\end{array}$ \\
\hline $\begin{array}{l}\text { VERA- } \\
4206\end{array}$ & $\begin{array}{l}\text { Rákóczifalva-Bagi- } \\
\text { föld } 8\end{array}$ & ECA & $\mathrm{F} 328 / \mathrm{S} 509$ & Animal bone & $5635 \pm 35$ & $-12.7 \pm 2.7$ & $4520-4400$ & $4540-4365$ & $\begin{array}{l}\text { Round pit } \\
\text { (Tiszapolgár and } \\
\text { Kisrétpart-style } \\
\text { pottery) }\end{array}$ & $\begin{array}{l}\text { Szilágyi 2015: } \\
\quad 204\end{array}$ \\
\hline $\begin{array}{l}\text { VERA- } \\
4204\end{array}$ & $\begin{array}{l}\text { Rákóczifalva-Bagi- } \\
\text { föld } 8\end{array}$ & ECA & F400/S617 & Homo sapiens & $5555 \pm 40$ & $-13.9 \pm 2.4$ & $4450-4350$ & $4460-4335$ & $\begin{array}{l}\text { Grave, Tiszapolgár- } \\
\text { style tumbler, } \\
\text { fragments of } 2 \\
\text { vessels, animal } \\
\text { bone tool }\end{array}$ & $\begin{array}{l}\text { Szilágyi 2015: } \\
\quad 208\end{array}$ \\
\hline $\begin{array}{r}\text { VERA- } \\
4205\end{array}$ & $\begin{array}{l}\text { Rákóczifalva-Bagi- } \\
\text { föld } 8\end{array}$ & ECA & F425/S663 & Homo sapiens & $5530 \pm 35$ & $-16.7 \pm 2.0$ & $4445-4340$ & $4450-4330$ & $\begin{array}{l}\text { Grave, } 4 \text { Tiszapolgár- } \\
\text { style vessels, } \\
\text { sherds, obsidian } \\
\text { and flint blades, } \\
\text { wild boar } \\
\text { mandible, animal } \\
\text { bones }\end{array}$ & $\begin{array}{l}\text { Szilágyi 2015: } \\
\quad 209\end{array}$ \\
\hline $\begin{array}{l}\text { VERA- } \\
4207\end{array}$ & $\begin{array}{l}\text { Rákóczifalva-Bagi- } \\
\text { föld } 8\end{array}$ & ECA & $\mathrm{F} 330 / \mathrm{S} 511,528$ & Animal bone & $5415 \pm 30$ & $-19.8 \pm 1.6$ & $4330-4260$ & $4345-4230$ & $\begin{array}{l}\text { Round pit } \\
\text { (Tiszapolgár and } \\
\text { Kisrétpart-style } \\
\text { pottery) }\end{array}$ & $\begin{array}{l}\text { Szilágyi 2015: } \\
\quad 204\end{array}$ \\
\hline Poz-50904 & $\begin{array}{l}\text { Rákóczifalva- } \\
\text { Bivaly-tó } 1 / c\end{array}$ & MCA & F557/754 & $\begin{array}{l}\text { Small ruminant, } \\
\text { Scapula Dex. } \\
\text { Frg. }\end{array}$ & $5470 \pm 35$ & $-22.4 \pm 0.4$ & $4355-4265$ & $4370-4245$ & $\begin{array}{l}\text { Pit (pottery, animal } \\
\text { bones, daub, shell) }\end{array}$ & $\begin{array}{l}\text { Szilágyi 2015: } \\
\quad 170\end{array}$ \\
\hline Poz-50905 & $\begin{array}{l}\text { Rákóczifalva- } \\
\text { Bivaly-tó 1/c }\end{array}$ & MCA & F494/971 & $\begin{array}{l}\text { Ovis, Calcaneus } \\
\text { Dex. }\end{array}$ & $5450 \pm 40$ & $-21.4 \pm 0.2$ & $4350-4260$ & $4365-4235$ & $\begin{array}{l}\text { Pit (pottery, animal } \\
\text { bones, daub, shell) }\end{array}$ & $\begin{array}{l}\text { Szilágyi 2015: } \\
\quad 165\end{array}$ \\
\hline Poz-50902 & $\begin{array}{l}\text { Rákóczifalva- } \\
\text { Bivaly-tó } 1 / \mathrm{c}\end{array}$ & MCA & F467/563 & $\begin{array}{l}\text { Large ungulate } \\
\text { long bone Frg. }\end{array}$ & $5350 \pm 40$ & $-24.4 \pm 2.1$ & $4315-4070$ & $4325-4050$ & $\begin{array}{l}\text { Pit (pottery, animal } \\
\text { bones, daub) }\end{array}$ & $\begin{array}{l}\text { Szilágyi 2015: } \\
\quad 162\end{array}$ \\
\hline
\end{tabular}


Table 1 (Continued)

\begin{tabular}{|c|c|c|c|c|c|c|c|c|c|c|}
\hline Lab. no. & Site & Period & Feature & Material & $\begin{array}{l}{ }^{14} \mathrm{C} \text { age } \\
\text { (BP) }\end{array}$ & $\begin{array}{l}\delta^{13} \mathrm{C}(\%) \\
(1 \sigma)\end{array}$ & $\begin{array}{l}\text { cal BC } \\
(68.2 \%)\end{array}$ & $\begin{array}{l}\text { cal BC } \\
(95.5 \%)\end{array}$ & $\begin{array}{l}\text { Archaeological } \\
\text { context, grave goods }\end{array}$ & References \\
\hline Poz-50906 & $\begin{array}{l}\text { Rákóczifalva- } \\
\text { Bivaly-tó } 1 / \mathrm{c}\end{array}$ & MCA & F469/567 & $\begin{array}{l}\text { Lepus europaeus } \\
\text { humerus Sin. } \\
\text { Frg. }\end{array}$ & $5315 \pm 35$ & $-20.8 \pm 0.5$ & $4235-4055$ & $4255-4040$ & $\begin{array}{l}\text { Large pit (pottery, } \\
\text { animal bones, } \\
\text { lithics, daub, shell } \\
\text { and snails) }\end{array}$ & $\begin{array}{l}\text { Szilágyi 2015: } \\
\quad 162\end{array}$ \\
\hline OxA-24907 & $\begin{array}{l}\text { Rákóczifalva- } \\
\text { Bivaly-tó } 1 / \mathrm{c}\end{array}$ & MCA & F542/S893 & Homo sapiens & $5466 \pm 33$ & $\begin{array}{r}-19.74 \\
\quad(\mathrm{AMS})\end{array}$ & $4355-4265$ & $4365-4255$ & $\begin{array}{l}\text { Grave in a pit, } 7 \\
\text { vessels, stone } \\
\text { knife, animal bone }\end{array}$ & $\begin{array}{l}\text { Szilágyi 2015: } \\
\quad 169\end{array}$ \\
\hline Poz-50901 & Tiszavalk-Tetes & MCA & Grave 9 & $\begin{array}{l}\text { Homo sapiens, } \\
\text { cranium }\end{array}$ & $5400 \pm 40$ & $-21.7 \pm 0.7$ & $4330-4235$ & $4345-4070$ & $\begin{array}{l}\text { Infans II, E-W } \\
\text { oriented, lying on } \\
\text { the left side in } \\
\text { crouched position, } \\
6 \text { Tiszapolgár- } \\
\text { Bodrogkeresztúr } \\
\text { style vessels, } 2 \\
\text { gold pendants, } 594 \\
\text { stone beads, sheep } \\
\text { bones }\end{array}$ & $\begin{array}{l}\text { Patay 1978: } 34, \\
\text { 36, 11, fig. } \\
\text { 1-2, 6-8, 11, } \\
\text { 12. fig., 13. } \\
\text { fig. 1-2, fig. } \\
\text { 14.; } \\
\text { Zoffmann } \\
\text { 1986; Vörös } \\
\text { 1986: } 77\end{array}$ \\
\hline Poz-50900 & Tiszavalk-Tetes & MCA & Grave 1 & $\begin{array}{l}\text { Homo sapiens, } \\
\text { costa }\end{array}$ & $5370 \pm 35$ & $-20.9 \pm 0.2$ & $4325-4080$ & $4335-4055$ & $\begin{array}{l}\text { Male, E-W oriented, } \\
\text { lying on the right } \\
\text { side, } 2 \\
\text { Tiszapolgár- } \\
\text { Bodrogkeresztúr } \\
\text { style vessels, } 2 \\
\text { obsidian } \\
\text { arrowheads, } \\
\text { copper pin and } \\
\text { stick, } 2 \text { fragments } \\
\text { of long flint } \\
\text { blades, chipped } \\
\text { stones, flint } \\
\text { arrowhead, cattle } \\
\text { and sheep/goat } \\
\text { bones, wild boar } \\
\text { tusk pendant }\end{array}$ & $\begin{array}{l}\text { Patay 1978: } \\
\text { 22-23, fig. } 2 \text {, } \\
\text { fig. 3.1, fig. } \\
\text { 4.1-32; } \\
\text { Zoffmann } \\
\text { 1986; Vörös } \\
\text { 1986: } 76\end{array}$ \\
\hline
\end{tabular}


Table 2 Posterior density estimates for the start and end of different sites, and the estimated span of activity on ECA and MCA sites. For local model see Appendix 1, for regional model see Appendix 2. All probability distribution is given in $68.2 \%$ probability.

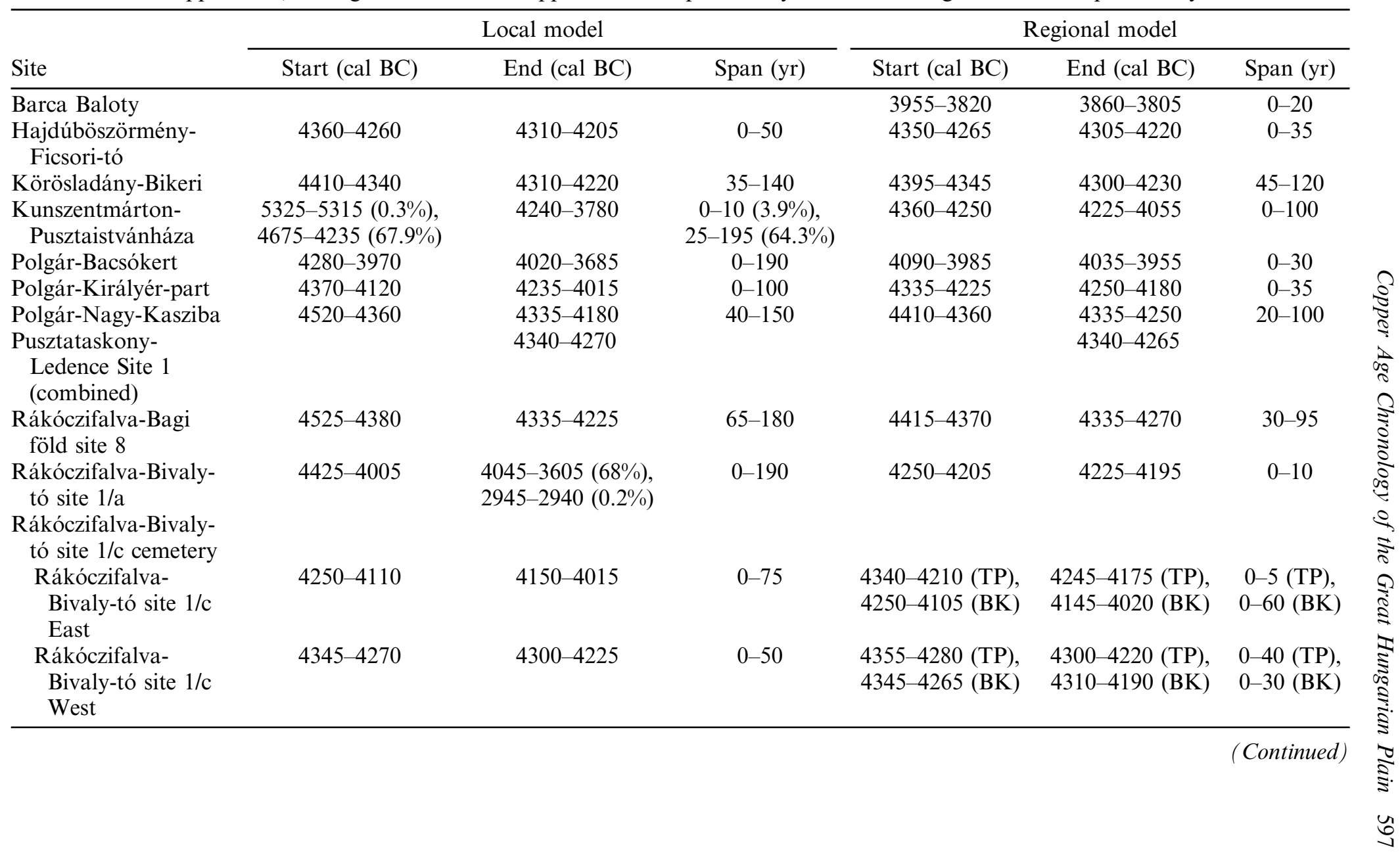




\begin{tabular}{|c|c|c|c|c|c|c|}
\hline \multirow[b]{2}{*}{ Site } & \multicolumn{3}{|c|}{ Local model } & \multicolumn{3}{|c|}{ Regional model } \\
\hline & Start (cal BC) & End (cal BC) & Span (yr) & Start (cal BC) & End (cal BC) & Span (yr) \\
\hline $\begin{array}{l}\text { Rákóczifalva-Bivaly- } \\
\text { tó site } 1 / \mathrm{c} \text { settlement }\end{array}$ & $4380-4285$ & $4295-4125$ & $15-150$ & $4355-4280$ & $4290-4155$ & $5-110$ \\
\hline Tiszalúc-Sarkad & & & & $3950-3810$ & $3880-3785$ & $0-20$ \\
\hline Tiszapolgár-Basatanya & $4405-4280$ & $4045-3890$ & $250-375$ & $\begin{array}{l}4395-4325(\mathrm{TP}) \\
4235-4060(\mathrm{BK})\end{array}$ & $\begin{array}{l}4345-4245(\mathrm{TP}) \\
4060-3960(\mathrm{BK})\end{array}$ & $\begin{array}{l}0-25(\mathrm{TP}), \\
0-115(\mathrm{BK})\end{array}$ \\
\hline Tiszavalk-Tetes & $4490-4230$ & $4315-4030$ & $0-65$ & $4345-4250$ & $4310-4145$ & $0-40$ \\
\hline Uivar & $4445-4270$ & $4340-4165$ & $0-40$ & $4375-4275$ & $4335-4235$ & $0-25$ \\
\hline Vésztő-Bikeri & $4410-4340$ & $4360-4305$ & $0-105$ & $4410-4365$ & $4340-4265$ & $0-95$ \\
\hline Vinča-Belo Brdo & $\begin{array}{l}5040-5030(0.3 \%), \\
4560-4250(68.9 \%)\end{array}$ & $\begin{array}{c}4305-3915(67.9 \%), \\
3415-3410(0.3 \%)\end{array}$ & $0-155$ & $4350-4270$ & $4265-4085$ & $0-85$ \\
\hline
\end{tabular}




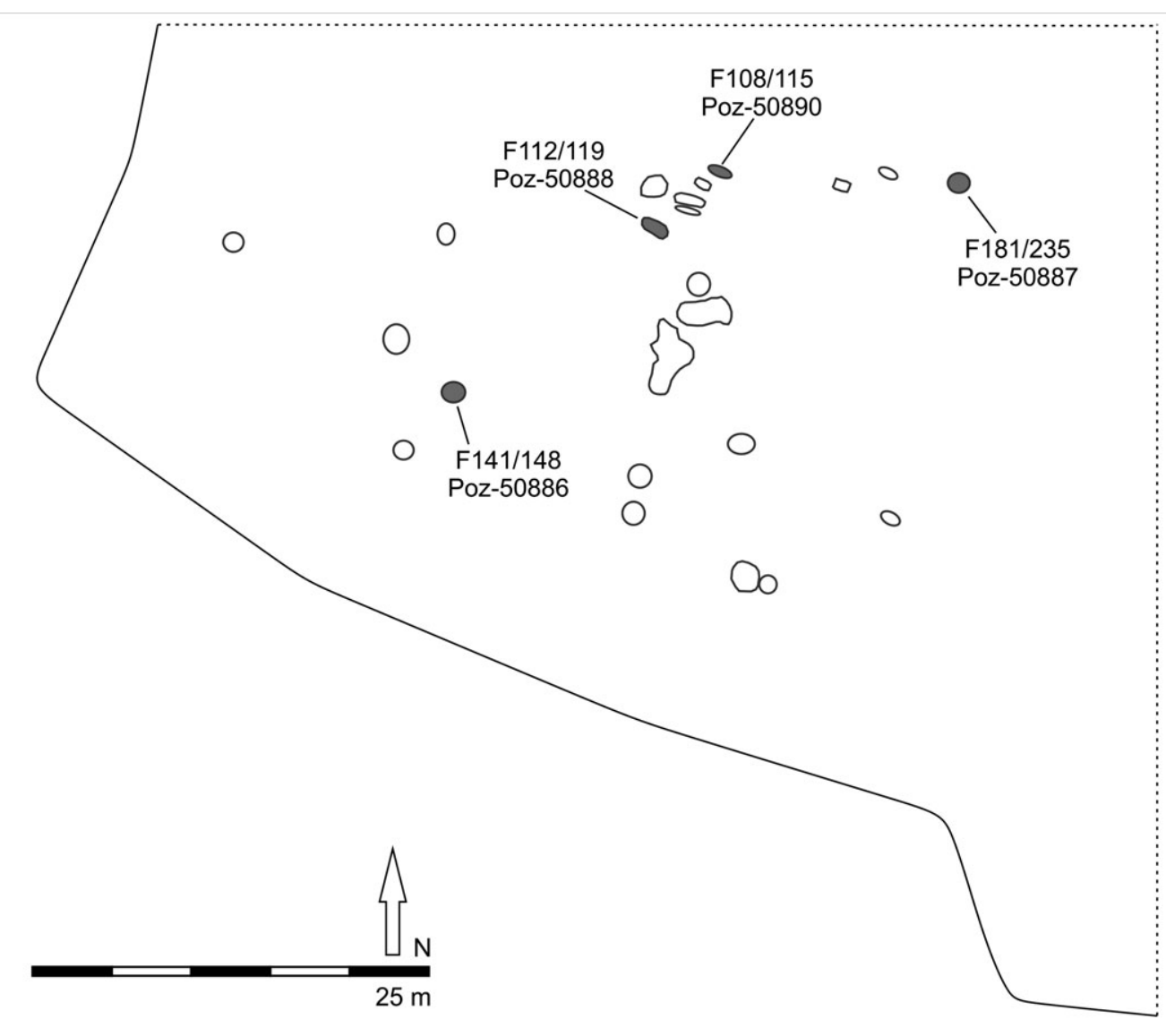

Figure 2 Map of the excavation in Polgár-Királyér-part highlighting the AMS-dated features.

them constituted a regular row. The settlement features were scattered in the same area as the graves (Figure 2). The site provided a small amount of uniform Tiszapolgár style pottery (Szilágyi 2015: 130-141).

The main pottery shapes in the settlement features were the flowerpot-shaped vessels $(65 \%$, Bognár-Kutzián type C), jars (Bognár-Kutzián type E) and profiled bowls (Bognár-Kutzián type K2). Almost exclusively plastic decoration was used with only 5\% lentil-shaped dot impressions.

We collected samples from both graves and settlement features. One date of an animal bone taken from Pit F181/235 proved to be Middle Neolithic (Poz-50887, Table 1), most probably derived from the LBK settlement excavated at the site. A sample from the amorphous Pit F141/ 148 (Poz-50886) and the Grave F112/119 (Poz-50888) supported our hypothesis that the burials and the use of the settlement were contemporaneous. The grave contained an adult woman and two children with a pedestalled jar (Bognár-Kutzián Period I type I) and a jar (Bognár-Kutzián Period I type E1). In the same row, the Grave F108/115 (Poz-50890) contained a tumbler (Bognár-Kutzián Period I type A), a profiled bowl (Bognár-Kutzián Period I type K2) and 
further two vessels that could not be precisely typologized due to their fragmentation. According to Bayesian modeling, the start of the use of the site is estimated to 4370 $(68.2 \%) 4120 \mathrm{cal} \mathrm{BC}$, the end of its use could be $4235(68.2 \%) 4015 \mathrm{cal} \mathrm{BC}$, the span of its use could be $0(68.2 \%) 100$ years (Table 2).

\section{Polgár-Nagy-Kasziba}

The site is located on the eastern bank of the Kengyel creek which was formerly a branch of the Tisza River. An area of 1 hectare was excavated during the rescue excavations of the M3 motorway construction in 1996 (Hajdú and Nagy 1999: 149). At the northern edge of the excavation area, four ECA graves were found. The graves of a man (Grave 39/41) and a woman (Grave 38/40) were situated next to each other, and further two children burials were found close to them (Grave 1/1 and 14/16). Raczky et al. (1997) assumed that they belonged to a larger cemetery and were members of a nuclear family. The graves contained numerous Tiszapolgár style vessels (Solnay 2018). Grave 39/41 (Poz-50895) contained three tumblers (Bognár-Kutzián Period I variant A1 and A2), three jars (Bognár-Kutzián Period I variant E1), a pedestalled bowl (Bognár-Kutzián Period I variant $\mathrm{H} 1$ ), a pedestalled goblet (Bognár-Kutzián Period I variant I1) and a fragment of a pedestalled vessel (Solnay 2018: 186-188).

The female burial (Grave 38/40, Poz-50894) found in a supine position next to the male grave was accompanied by four tumblers (Bognár-Kutzián Period I variant A1 and A2), a flowerpotshaped vessel (Bognár-Kutzián Period I variant C2), two jars (Bognár-Kutzián Period I variant E1 and E2), a hollow-pedestalled bowl (Bognár-Kutzián Period I variant H3), a hollowpedestalled goblet (Bognár-Kutzián Period I variant I1), a hollow-pedestalled globular vessel, a bowl (Bognár-Kutzián Period I variant K1), a cup (Bognár-Kutzián Period I variant L1), and a minor vessel. A belt made of stone beads was found around the waist (Solnay 2018: 184-186). The third, AMS-dated grave (Grave 14/16, Poz-50896) was a child in a supine position accompanied by a vessel and a copper bracelet (Solnay 2018: 183). Bayesian modeling estimates the beginning of the burials to $4520(68.2 \%) 4360 \mathrm{cal} \mathrm{BC}$ and the end at $4335(68.2 \%) 4180 \mathrm{cal} \mathrm{BC}$. They were buried in a $40(68.2 \%) 150$ years span (Table 2). According to ${ }^{14} \mathrm{C}$ measurements, the man and the child could have been buried in one period, while the female grave belongs to an earlier period. Based on this, it is unlikely that the deceased were members of a nuclear family.

\section{Rákóczifalva Microregion}

The sites around Rákóczifalva are located in a well-defined microregion bounded to the north, west, and south by the Tisza River, its meanders and its floodplain. The area was opened only from the southeast, joining the plains of Martfü and Kengyel.

During the excavations before the flood protection earthworks in 2005-2007, three ECA and MCA sites were found.

\section{Rákóczifalva-Bagi-föld Site 8}

In 2006-2007, 4.4 hectares of a multiperiod site were excavated. The area was split into two sondages, and although the CA features were scattered throughout the whole excavation, a concentration could be observed in the north-northeastern part of the eastern sondage, site 8 (Figure 3). This central part of the settlement is surrounded by a ditch, a building, two wells, and several large pits were found here. The pottery material belongs to the Kisrétpart group. To the west, the traces of the CA settlement are sporadic. There is a total of nine 


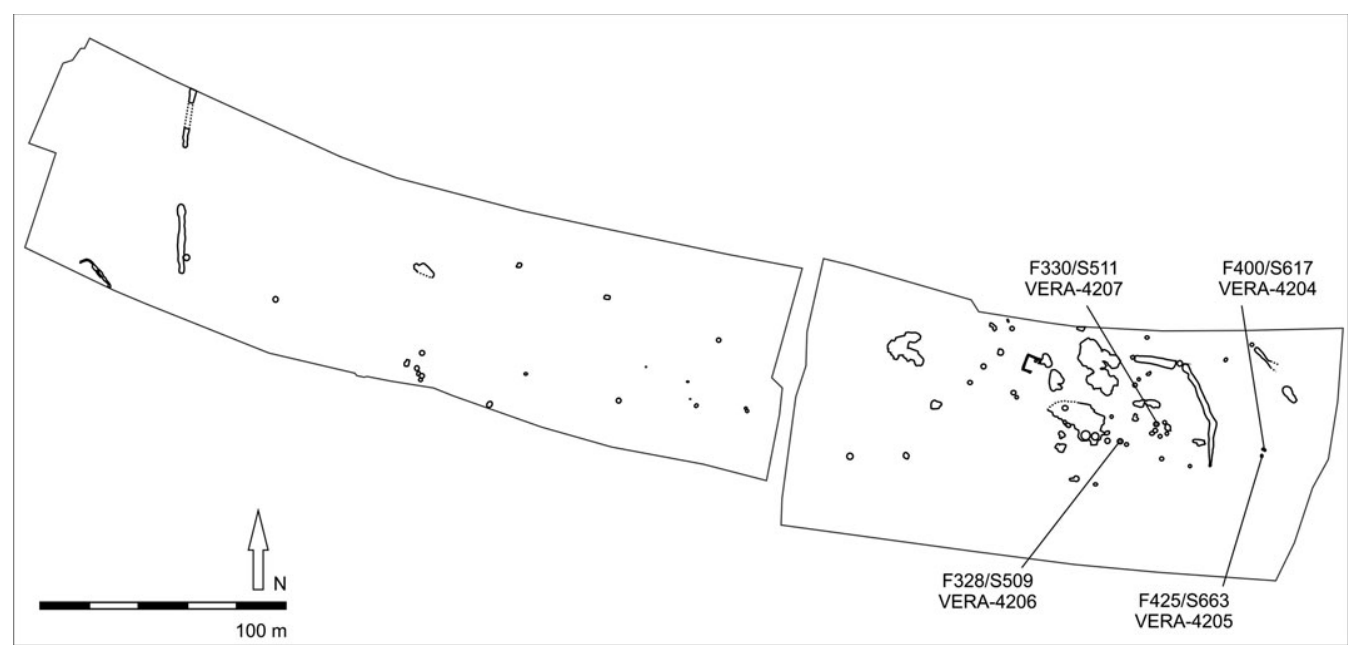

Figure 3 Map of the excavation in Rákóczifalva-Bagi föld site 8 highlighting the AMS-dated features.

ECA-MCA graves, two of which are located next to each other outside the ditch. A child burial without grave goods was discovered in the filling of a pit. In the western part of the site, in the scattered part of the settlement two adult and several children burials were found (Szilágyi 2015: 196-209).

We took samples from two graves which were found at the eastern edge of the excavation. They were proven to be contemporaneous. The Grave F400/S617 (VERA-4204) was of an east-west oriented adult lying in a crouched position on its right side. The burial contained three vessels (a tumbler and two unidentifiable vessels), and an animal bone tool. The nearby Grave F425/S663 (VERA-4205) was also east-west oriented; the deceased was laid in a crouched position on its right side. The grave goods were fragments of three vessels (one of them was probably a mug, Bognár-Kutzián period I type B), obsidian and flint blades, wild boar mandibles and further animal bones. The lower part of the skeleton was cut by a Sarmatian ditch, so further broken sherds may have been the remains of other vessels (Table 1). The few decorated fragments bear the characteristics of the Kisrétpart group.

We took two samples from two pits from the densest, central part of the settlement. The older sample from the F328/S509 pit (VERA-4206) and the younger sample from the Pit F330/S511, 528 (VERA-4207) suggest a longer use of the settlement (Table 1). According to Bayesian modeling, the start of the activity on the site could estimate at $4525(68.2 \%) 4380 \mathrm{cal} \mathrm{BC}$, it might end at $4335(68.2 \%) 4225 \mathrm{cal} \mathrm{BC}$, and the span of its use could be estimated 65 $(68.2 \%) 180$ years (Table 2).

The pottery assemblage showed a rather homogeneous picture. Among the vessel shapes, conical bowls represented the highest proportion (40\%) (Bognár-Kutzián Period I type K1, both pedestalled and flat bottom variants). Furthermore, two vessel types were found in higher proportions, the jars $(22 \%$, Bognár-Kutzián Period I type E) and the S-profiled bowls (16\%, Bognár-Kutzián I period type K3). Eleven further vessel types were present in $1-4 \%$ each. The incised decoration can be linked to the Kisrétpart style. According to the principal component analysis and correspondence analysis, the pottery assemblages found 
in the pits were parts of a roughly uniform pottery set. No changes of the vessel shapes, ornamental motifs and techniques could be detected over time (Szilágyi 2015: 223-230).

\section{Rákóczifalva-Bivaly-tó 1/a}

The multiperiod site was excavated in 2006-2007. The ECA features were scattered at its western edge and NE of it (Csányi 2007: 259; Szilágyi 2015: 142-155). Apart from the usual settlement pits, a burial was found surrounded by a shallow circular ditch (Figure 4).

The AMS samples were taken from two pits from different parts of the settlement. The round Pit F438/S499 was located in the eastern part of the settlement, and the Poz-50907 measurement provided a surprisingly young date considering the style of pottery found within it. The other sample was taken from the irregular shallow Pit F920/S1372 in the western part of the settlement (Poz-50908, Table 1).

The most common vessel shapes were the conical bowls (45\%, Bognár-Kutzián Period I type K1), rounded bowls (17\%, Bognár-Kutzián Period I, types K2g and L2, Period II type K1) and profiled bowls (13\%, Bognár-Kutzián Period I type K2). Jars were found in a relatively high number ( $8 \%$, Bognár-Kutzián Period I type E), while the other vessel types occurred in 1-4\% each. The low proportion $(2 \%)$ of incised decoration was striking, and the motifs could be linked to the Kisrétpart style. Due to the very low number of decorated pieces and the frequency of the Tiszapolgár shapes, the assemblage can be defined as classic Tiszapolgár, although there are a few elements pointing to the Bodrogkeresztúr style (i.e. net pattern). Based on the principal component analysis, the sherds originate from a uniform pottery set which shows no sign of temporal transformation (Szilágyi 2015: 158-159, Figure 49).

Despite the stylistically homogeneous pottery assemblage of the settlement, the Bayesian model based on two ${ }^{14} \mathrm{C}$ samples estimated the start of the activity to $4425(68.2 \%) 4005 \mathrm{cal} \mathrm{BC}$, the end of its use to $4045(68 \%) 3605 \mathrm{cal} \mathrm{BC}$, and the span of use between $0(68.2 \%) 190$ years (Table 2). Further ${ }^{14} \mathrm{C}$ measurements are required to date the site more accurately.

\section{Rákóczifalva-Bivaly-tó 1/c}

The ECA-MCA settlement is located about 150 m northwest of the CA cemetery excavated at the same site. The cemetery and the settlement are entirely separated due to a 120-140-m empty area. The settlement was situated on the northwestern part of the excavation, on an approximately $50 \times 50-\mathrm{m}$ area. Based on the distribution and density of the CA features, the whole settlement was unearthed with high probability. The settlement consists of 30 features, two of which are buildings with bedding trenches, one is a settlement burial, and the rest are pits (Figure 5). Some of the pits contained only a low number of finds, some of them can only uncertainly be dated to the CA (Szilágyi 2015: 160-171).

Animal bone samples were taken from four settlement pits. Pits F467/S563 (Poz-50902), F494/ S971 (Poz-50905) and F557/S754 (Poz-50904) (Table 1) were located near to each other in the northern part of the settlement. The latter two pits are contemporaneous with the grave of a 2329-year-old male buried into the CA Pit F542/S893 (OxA-24907) (Zoffmann 2011). The burial was found at $100 \mathrm{~cm}$ depth in the filling of the deep oval pit. The east-west oriented crouched skeleton was lying on its left side and was accompanied by rich grave goods (Table 1). The fourth sample was taken from a large rounded pit (F469/S567) which was located at the southern edge of the settlement. According to the Poz-50906 measurement, it can be dated to a younger period (Table 1). Therefore, the possibility of a chronological difference between the northern and southern parts of the settlement cannot be excluded. 


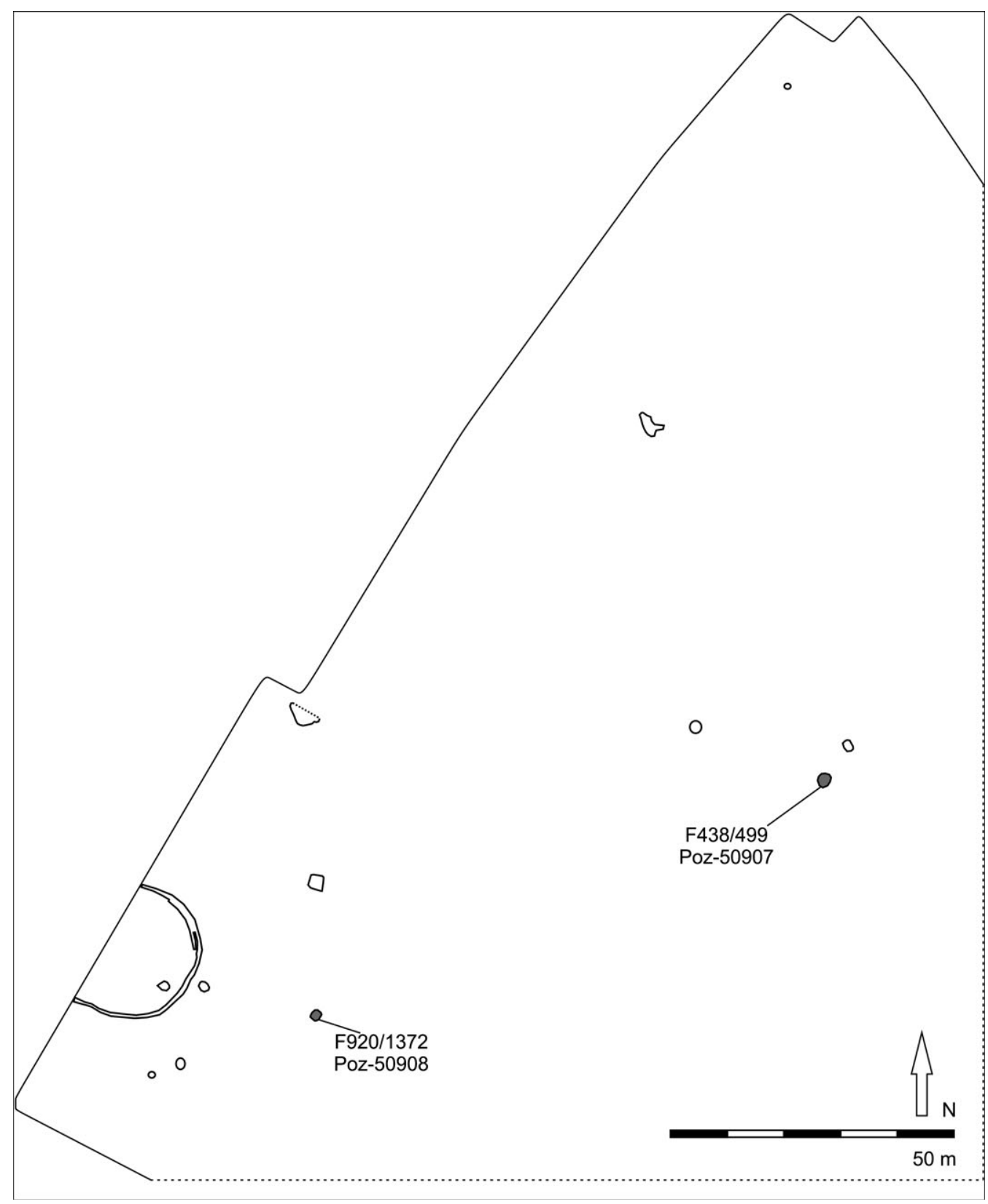

Figure 4 Map of the excavation in Rákóczifalva-Bivaly-tó site 1/a highlighting the AMS-dated features.

The settlement pottery can be linked to both the Kisrétpart and the Bodrogkeresztúr styles. The principal component analysis and correspondence analysis of the settlement pottery show a uniform set of vessel shapes. Approximately two-thirds $(65 \%)$ of the vessel shapes are of various types of bowls (pedestalled or flat-bottom variants). Among these, the most common shape is the simple conical bowl (Bognár-Kutzián Period I type K1), followed by rounded or spherical, generally two-handled bowls (Bognár-Kutzián Period II type K) and 


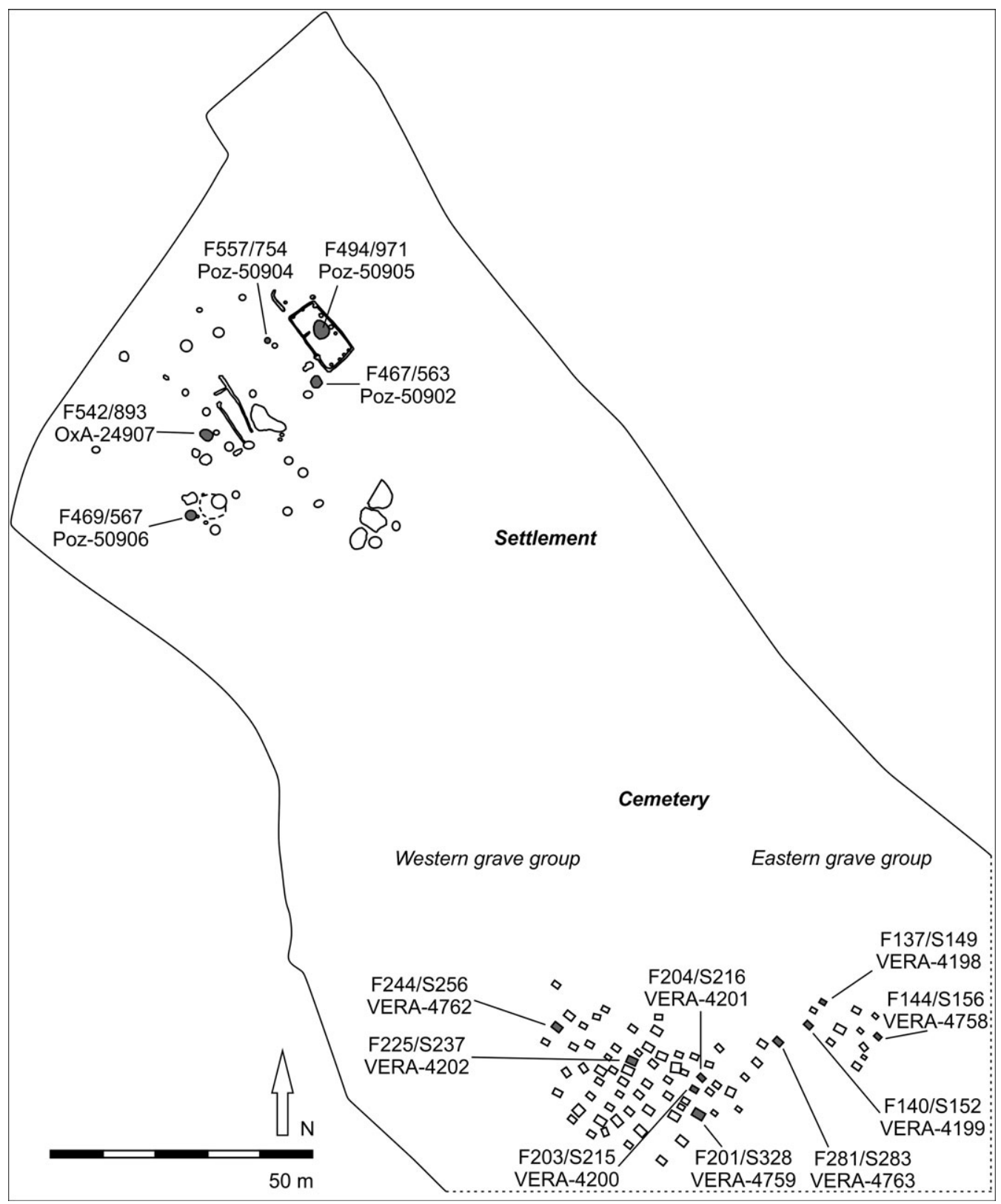

Figure 5 Map of the excavation in Rákóczifalva-Bivaly-tó site 1/c highlighting the AMS-dated features.

profiled bowls (Bognár-Kutzián Period I type K2). Jars (8\%, Bognár-Kutzián Period I type E) and flowerpot-shaped vessels (9\%, Bognár-Kutzián Period I type C) occurred relatively frequently. The remaining less than $20 \%$ is shared by 11 vessel types which occur rarely or sporadically, never reaching the $5 \%$ proportion. The result of comparing pottery assemblages from settlement features to each other also suggests a uniform pottery set, a similar combination of vessels was found in each pit. 
At the same time, according to the incised decoration, three stylistic groups can be distinguished, which can also be spatially differentiated within the settlement. The first group is dominated by the geometric ornaments and rows of impressed lentil-shaped dots and stabbed geometric ornaments, the second group is dominated by stabbed line patterns and incised hatched motifs, while the third group is dominated by incised motifs filled with net patterns. The motifs of the first two groups are traditionally considered to be the characteristics of the Kisrétpart group or the Tiszapolgár-Bodrogkeresztúr transitional period, while the decoration style of the third group can be linked to the Bodrogkeresztúr culture. The picture is, however, significantly modified by the fact that in each group all the ornamental motifs are present, with only minor differences in their proportion. Considering the results of AMS dating, these clusters can rather be explained as a gradual, subtle change in ceramic style and a slight spatial shift of the settlement than real stylistic groups or phases (Szilágyi 2015: 182-195).

Altogether, 79 graves were excavated in the cemetery located southeast of the settlement. The graves were situated in a relatively narrow area of $35 \times 60 \mathrm{~m}$ in two distinct groups. The 64 graves of the western group and the 11 graves of the eastern group were arranged into more or less regular rows. A row of four graves can be seen as a link between the two groups (Csányi et al. 2010). Based on both the burial rite and the finds (heavy copper tools, long Volhynian flint blades, gold pendants, and milk jugs) the cemetery fits well with the previously known Bodrogkeresztúr cemeteries. Its value is further enhanced by the fact that it was excavated and documented following the modern standards, and that the entire cemetery and the settlement were fully unearthed.

The stylistic affiliation of the cemetery seemed to be quite apparent at first glance. Although the evaluation of the cemetery is still in progress, the preliminary examination of the pottery raised several questions. It seems that not only Bodrogkeresztúr elements appear in the graves but also classic Tiszapolgár and Kisrétpart characteristics can be observed in the pottery assemblage. Moreover, there is a Scheibenhenkel-like plastic decoration (an applied cordon with discoid ends) on one of the pots that is typical of the Hunyadihalom style. Apart from this, the pottery material from the cemetery was also strikingly different from that of the settlement. In addition to the stylistic differences, there was a small amount of decorated pottery in the cemetery, and these decorations were often whipped up compared to the carefully designed and executed incised decoration on the settlement pottery.

The use of the settlement could have begun in $4380(68.2 \%) 4285 \mathrm{cal} \mathrm{BC}$. Contemporarily or a little later, the use of the western grave group could have begun in $4345(68.2 \%) 4270 \mathrm{cal} \mathrm{BC}$. The western grave group was used for a short $\operatorname{span}(0(68.2 \%) 50$ years $)$ and could have been finished around $4300(68.2 \%) 4225 \mathrm{cal} \mathrm{BC}$. The use of the cemetery could be practically continuous, as the use of the younger, eastern group could have started around 4250 $(68.2 \%) 4110 \mathrm{cal} \mathrm{BC}$. The opening of the eastern grave group may have happened at about the same time of abandoning the settlement, around $4295(68.2 \%) 4125 \mathrm{cal} \mathrm{BC}$. The eastern group could be used for a short span as well, for $0(68.2 \%) 75$ years and could be ended around $4150(68.2 \%) 4015 \mathrm{cal} \mathrm{BC}$.

The dates from the settlement features and the eastern group of the cemetery raise the possibility that the graveyard could be used even after the settlement had been abandoned. At the same time, it cannot be excluded that the southern part of the settlement, which is currently dated only by one measurement, could have remained in use during the use of the 
eastern grave group. Although the radiocarbon data show a chronological difference in the use of certain areas at both the settlement and the cemetery and some stylistic differences of pottery were also observable, there is no clear correlation between them. In fact, in the graves of the western, older group of the cemetery, all of the above-mentioned ceramic styles occurred.

\section{Further Sites on the Great Hungarian Plain}

\section{Berettyóújfalu-Berettyólapos-Sertéshízlalda}

In 2012 during a test excavation before the construction of a dam along the Berettyó River, a part of a Tiszapolgár settlement was discovered. Two large settlement pits were sampled, the Poz-50884 sample from F4/S4 pit contained too little collagen; thus, it was excluded from the analysis. A sample from the F5/S5 pit containing classic Tiszapolgár style ceramics (Poz-50885) can be dated to $4325(68.2 \%) 4070$ cal BC (Table 1). Although far-reaching conclusions cannot be drawn from this small-scale excavation, the site provides a valuable glimpse into the ECA settlement pattern in the Berettyó valley, as it is located $2 \mathrm{~km}$ south-southeast of the Berettyóújfalu-Szilhalom tell settlement where an ECA layer was unearthed (Neumann et al. 2014).

\section{Jászberény-Borsóhalom}

The site is located on the bank of the Nyavalka creek and was excavated by Zs. Csalog in 1952 and 1953. Traces of a contemporaneous settlement were also found on the other bank of the watercourse (Csalog 1961: 53, 147). Altogether, 17 graves were excavated, and the remains of another eight burials were heavily damaged. The burials were located in an area of $170 \mathrm{~m}^{2}$, and the excavation covered a total of $325 \mathrm{~m}^{2}$. Based on these facts the cemetery can be considered fully excavated (Csalog 1961: 55).

The Grave 17 was of an SW-NE oriented individual lying in a crouched position on its right side. A hemispherical bowl decorated with a red slip, a dipper decorated with a stylized animal head and a flint blade were found within the grave (Raczky 1988: 33, figs 30-31). Raczky dedicated special attention to the slip decoration in his work on the cultural and chronological relations of the CA between the GHP and the Aegean (Raczky 1988: 34-37, 1991: 329-331). Grave 17 (Poz-50897) can be dated to 4230 (68.2\%) 3995 cal BC (Table 1).

\section{Kunszentmárton-Pusztaistvánháza}

The site is located on the bank of a former Körös riverbed. The first finds were discovered during dam construction works in 1919, then J. Hillebrand excavated 33 graves in 1925 and 1927. Hillebrand estimated that at least eight graves were destroyed during the earthworks. In his opinion, the entire cemetery was unearthed (Hillebrand 1929: 15-16) but Patay disagreed (Patay 1961: 41). Grave goods include vessels of both Tiszapolgár and late Bodrogkeresztúr styles, so Patay dated some graves to the transitional period (Patay 2008: 29-30). Only a few skeletons of the old excavation survived the later decades; thus, our sampling strategy was severely limited. Despite these circumstances, the cemetery is essential because of its transitional character.

A slightly crouched, E-W oriented individual was laid on its right side in Grave 15 (Poz-50898). Its grave goods were five vessels and a long flint blade (Hillebrand 1929: 16; Patay 1961: 46). Patay dated the burial to the Tiszapolgár-Bodrogkeresztúr transitional period (Patay 1979: 47). The skeleton found in Grave 29 (Poz-50899) was oriented to $\mathrm{E}-\mathrm{W}$ in a crouched position lying on its left side, but its upper body turned downwards. 
Its four vessels can be stylistically affiliated to Bodrogkeresztúr B (Table 1) (Hillebrand 1929: 26; Patay 1961: 50, 2008: 25, 30).

According to the two measurements, the grave considered to be stylistically transitional, and the one considered to be stylistically late, actually chronologically follow each other. According to Bayesian modeling, the start of the cemetery can be estimated to $4675(67.9 \%) 4235 \mathrm{cal} \mathrm{BC}$, the end of its use can be estimated to $4240(68.2 \%) 3780 \mathrm{cal} \mathrm{BC}$, and its span is estimated to be $0(68.2 \%) 195$ years (Table 2). The ample time intervals are due to the low number of measurements which could be refined with further measurements.

\section{Tiszavalk-Tetes}

Patay carried out a research excavation on $639 \mathrm{~m}^{2}$ between 1968 and 1975 on the bank of the Tetes creek. Apart from finds from several periods, $25 \mathrm{CA}$ graves and two large pits were discovered (Patay 1978: Figure 1). He dated the settlement features to the ECAMCA transitional period. He thought that the central part of the CA settlement remained unexcavated on the bank of the Tetes creek, the excavation revealed only the edge of the settlement. Besides, four later MCA Hunyadihalom features were found (Patay 1978, 1979).

A man was placed into Grave 1 oriented E-W who was lying in a crouched position on his right side (Poz-50900). The grave was cut by the Pit III/b and III/a, the latter contained Hunyadihalom finds. The grave goods were assigned to the transitional style (Patay 1978: 22-23, figs 2, 3.1 and 5, 4.1-32; 2008: 32-33). It would have been important to date the Hunyadihalom pit, which intersected the Grave 1 but the two animal bone samples collected from the pit provided Sarmatian (Poz-47461, $1885 \pm 35$ BP) and Árpádian Period dates (Poz-47462, $850 \pm 30 \mathrm{BP})$. Although the dating of the settlement would have been pressing in the understanding of the relation between the graves and the settlement features, and the use of different pottery styles, it was unsuccessful due to the mixed archaeozoological material.

An E-W oriented Inf. II. individual was lying in a crouched position on its left side in the Grave 9 (Poz-50901). The western edge of the grave was cut by Pit VII/d. Its grave goods were six Tiszapolgár and transitional-style vessels, two Magyartés-type gold pendants, a belt consisting of stone beads, and animal bones (Table 1) (Patay 1978: 34-36, figs 11.1-2, 6-8, 11-14; 2008: 32-33).

According to Bayesian modeling, the burials could have begun at around $4490(68.2 \%) 4230$ cal BC and ceased at $4315(68.2 \%) 4030 \mathrm{cal} \mathrm{BC}$. The estimated span of use could be $0(68.2 \%)$ 65 years (Table 2$)$.

The dating of the Tiszavalk-Tetes cemetery is essential because even Patay observed that the Tiszapolgár and Bodrogkeresztúr stylistic features are mixed in the graves; thus, he dated both the graves and the settlement to the transitional period. This mixture could be observed within the territory of the cemetery, and there is no evidence of the spatial separation between the Tiszapolgár and Bodrogkeresztúr styles (Patay 1979: 38). On the other hand, according to the dating of the Grave 9, the appearance of gold on the GHP can be dated much earlier than previously assumed, to $4330(68.2 \%) 4230 \mathrm{cal} \mathrm{BC}$. 


\section{Regional Chronology}

As the next step of our analysis, in addition to our measurements presented above, we collected all ECA and MCA radiocarbon dates from the entire GHP. With all these data, we built a model in which we treated the Tiszapolgár and Bodrogkeresztúr styles separately in different Sequences including stratigraphical information. Then, using the Difference command, we compared the end Boundary of the Tiszapolgár style and the start Boundary of the Bodrogkeresztúr style (Appendix 2). Within each of these Sequences, each site was treated separately. In the case of the sites where both ceramic styles could be observed, the measurements were separated feature by feature. Another model was built for dating the Hunyadihalom finds (Figure 6). Altogether, we could use a total of 86 measurements (Table 3). This is probably the largest Southeastern and Central European AMS database of this period.

In the modeling, we used only AMS dates and newer, conventional measurements with a standard error of no more than 50 years deriving from a known archaeological context. Exceptions were made only in case of some measurements from Körösladány- and VésztőBikeri (see below).

Recent measurements from the Deszk B site were excluded from the model because the numbering of graves from old excavations and the numbering of the material stored in museum deposits could not be satisfactorily identified. The results of AMS measurements indicate a serious mixing of the anthropological finds (Diaconescu 2014: 231-233). We also ignored the graves of Hódmezóvásárhely-Gorzsa, which was described by D. Diaconescu as "early stage of Tiszapolgár culture" (Diaconescu 2014: 226). Although, according to F. Horváth, the excavator of the site, the graves can be dated to the LN (Horváth 2005: 60-61, 2014: 298). This dating is also supported by AMS measurements of the graves (Diaconescu 2014: 232).

We could incorporate data into the model representing the Tiszapolgár style from Berettyóújfalu-Szilhalom (Neumann et al. 2014: 400, Figure 19), Malé Raškovce, Grave 1 (Brummack 2015: 5) and Vésztő-Mágor (Parkinson et al. 2004: 106; Yerkes et al. 2009: 1093). We also know two AMS measurements of two burials with Tiszapolgár style pottery from the Uivar tell (Schier 2013).

Three burials are dated by five measurements from the cemetery of HajdúböszörményFicsori-tó, located in the northern part of the GHP. The 34 graves of the fully excavated cemetery contained only Tiszapolgár-style vessels and, however, only a preliminary study is published (Kovács and Váczi 2007), these data can be used to date the classic Tiszapolgár style.

Most of the measurements are from the Tiszapolgár sites of Körösladány-Bikeri and Vésztô-Bikeri. The published stratigraphic information was built into the model of these sites (Yerkes et al. 2009: 1082-1085, 1093-1094). The dates Beta-214597 and Beta-234310 from Körösladány-Bikeri and dates Beta-162065, Beta-162067, Beta-179782 and Beta-214593 were excluded from the model because, except Beta-162067 and Beta-179782, they were significantly older. The last two dates are from above the floor layers of a longhouse (Yerkes et al. 2009: 1084) which resulted in significantly younger data. Although the material of the samples from these two sites was not published, it can be inferred from the text that the vast majority of the measurements were probably made from charcoal samples. This material may be the explanation for the 


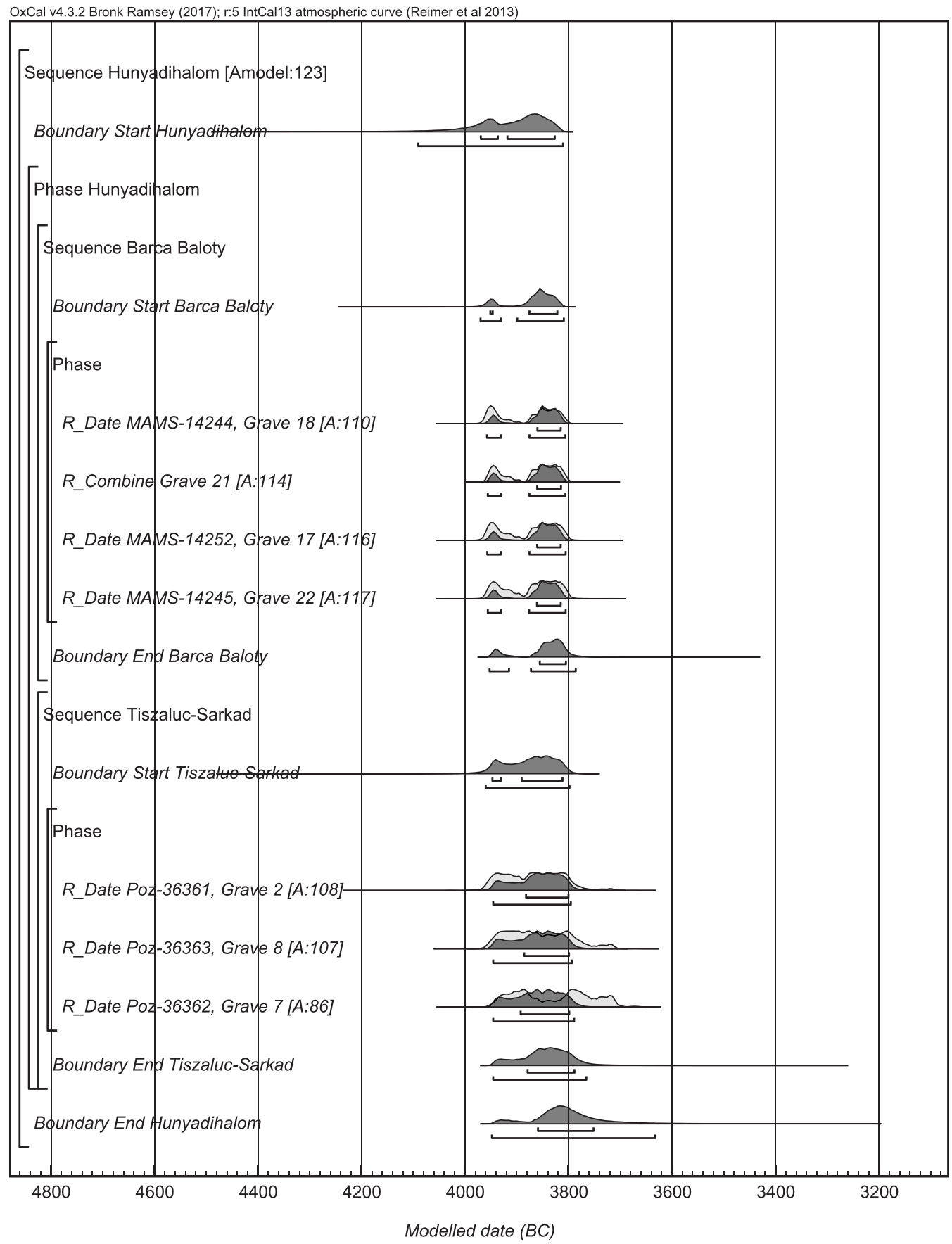

Figure 6 Probability distributions of radiocarbon dates from Hunyadihalom sites. The square brackets on the left side along with the OxCal keywords exactly define the model. 
Table 3 Radiocarbon dates from ECA and MCA sites and their archaeological context discussed in the study. $\delta^{13} \mathrm{C}$ values of the Poznan Radiocarbon Laboratory cannot be used for palaeoecological reconstructions because of the method of sample preparation.

\begin{tabular}{|c|c|c|c|c|c|c|c|c|c|}
\hline Lab. no. & Site & Feature & Material & $\begin{array}{l}\text { Radiocarbon } \\
\text { age (BP) }\end{array}$ & $\delta^{13} \mathrm{C}$ & $\begin{array}{l}\text { cal BC } \\
(68.2 \%)\end{array}$ & $\begin{array}{l}\text { cal BC } \\
(95.5 \%)\end{array}$ & $\begin{array}{l}\text { Archaeological } \\
\text { context, grave } \\
\text { goods }\end{array}$ & References \\
\hline MAMS-14243 & Barca Baloty & Grave 18 & $\begin{array}{l}\text { Homo sapiens, } \\
\text { front tooth }\end{array}$ & $5208 \pm 27$ & -19.1 & $4040-3975$ & $4050-3965$ & $\begin{array}{l}\text { ENE-WSW } \\
\text { oriented, lying on }\end{array}$ & $\begin{array}{l}\text { Brummack } \\
2015: 7 .\end{array}$ \\
\hline MAMS-14244 & Barca Baloty & Grave 18 & $\begin{array}{l}\text { Homo sapiens, } \\
\text { cranium }\end{array}$ & $5102 \pm 24$ & -16.9 & $3965-3810$ & $3970-3800$ & $\begin{array}{l}\text { the right side in } \\
\text { crouched position, }\end{array}$ & \\
\hline MAMS-14242 & Barca Baloty & Grave 18 & $\begin{array}{l}\text { Domestic pig, } \\
\text { ulna }\end{array}$ & $5002 \pm 29$ & -21.1 & $3895-3710$ & $3940-3700$ & $\begin{array}{l}2 \text { vessels, copper } \\
\text { dagger, silex } \\
\text { scraper, animal } \\
\text { bones }\end{array}$ & \\
\hline MAMS-14253 & Barca Baloty & Grave 21 & $\begin{array}{l}\text { Homo sapiens, } \\
\text { vertebra }\end{array}$ & $5102 \pm 26$ & -15.9 & $3965-3810$ & $3970-3800$ & $\begin{array}{l}4 \text { vessels, copper } \\
\text { dagger, flint }\end{array}$ & $\begin{array}{l}\text { Brummack } \\
2015: 7 .\end{array}$ \\
\hline MAMS-14250 & Barca Baloty & Grave 21 & $\begin{array}{l}\text { Homo sapiens, } \\
\text { cranium }\end{array}$ & $5074 \pm 27$ & -14.9 & $3950-3800$ & $3960-3795$ & $\begin{array}{l}\text { blade, strongly } \\
\text { disturbed }\end{array}$ & \\
\hline MAMS-14252 & Barca Baloty & Grave 17 & $\begin{array}{l}\text { Homo sapiens, } \\
\text { femur }\end{array}$ & $5096 \pm 27$ & -19.4 & $3960-3810$ & $3970-3800$ & $\begin{array}{l}\text { E-W oriented, } \\
\text { lying on the right } \\
\text { side in crouched } \\
\text { position, no grave } \\
\text { goods }\end{array}$ & $\begin{array}{l}\text { Brummack } \\
2015: 7 .\end{array}$ \\
\hline MAMS-14245 & Barca Baloty & Grave 22 & $\begin{array}{l}\text { Homo sapiens, } \\
\text { femur }\end{array}$ & $5088 \pm 27$ & -26.4 & $3955-3805$ & $3965-3795$ & $\begin{array}{l}2 \text { vessels, chipped } \\
\text { stone, strongly } \\
\text { disturbed }\end{array}$ & $\begin{array}{l}\text { Brummack } \\
2015: 7 .\end{array}$ \\
\hline MAMS-20505 & Berettyóújfalu-Szilhalom & F011/S040 & Animal bone & $5614 \pm 20$ & -21.8 & $4465-4370$ & $4495-4365$ & House debris & $\begin{array}{l}\text { Neumann et al. } \\
\text { 2014: } 400 \text {, fig. } 19 \text {. }\end{array}$ \\
\hline Poz-41865 & Csongrád-Kettőshalom & Grave 1 & Homo sapiens & $5470 \pm 40$ & n.a. & $4355-4265$ & $4445-4240$ & $\begin{array}{l}\text { 35-year-old male, } \\
\text { E-W oriented, } \\
\text { long obsidian } \\
\text { blade, copper, } \\
\text { bone and stone } \\
\text { beads, red ochre }\end{array}$ & $\begin{array}{l}\text { Ecsedy } 1974 ; \\
\text { Marcsik 1974; } \\
\text { Dani and Horváth } \\
2012: 75,79 .\end{array}$ \\
\hline VERA-3785 & $\begin{array}{l}\text { Hajdúböszörmény- } \\
\text { Ficsori-tó-dúlố }\end{array}$ & Grave $30 / 34$ & Homo sapiens & $5370 \pm 40$ & n.a. & $4325-4075$ & $4335-4055$ & n.a. & $\begin{array}{l}\text { Kovács and Váczi } \\
\text { 2007: } 408 .\end{array}$ \\
\hline VERA-3786 & $\begin{array}{l}\text { Hajdúböszörmény- } \\
\text { Ficsori-tó-dúlố }\end{array}$ & Grave $71 / 75$ & Homo sapiens & $5445 \pm 35$ & n.a. & $4345-4260$ & $4355-4240$ & n.a. & $\begin{array}{l}\text { Kovács and Váczi } \\
\text { 2007: } 408 .\end{array}$ \\
\hline VERA-3787 & $\begin{array}{l}\text { Hajdúböszörmény- } \\
\text { Ficsori-tó-dúlố }\end{array}$ & Grave $57 / 61$ & Homo sapiens & $5425 \pm 35$ & n.a. & $4335-4260$ & $4350-4230$ & n.a. & $\begin{array}{l}\text { Kovács and Váczi } \\
\text { 2007: } 408 .\end{array}$ \\
\hline VERA-3788 & $\begin{array}{l}\text { Hajdúböszörmény- } \\
\text { Ficsori-tó-dúlố }\end{array}$ & Grave $30 / 34$ & Animal bone & $5370 \pm 45$ & n.a. & $4330-4075$ & $4335-4055$ & n.a. & $\begin{array}{l}\text { Kovács and Váczi } \\
\text { 2007: } 408 .\end{array}$ \\
\hline
\end{tabular}


Table 3 (Continued)

\begin{tabular}{|c|c|c|c|c|c|c|c|c|c|}
\hline Lab. no. & Site & Feature & Material & $\begin{array}{l}\text { Radiocarbon } \\
\text { age (BP) }\end{array}$ & $\delta^{13} \mathrm{C}$ & $\begin{array}{l}\text { cal BC } \\
(68.2 \%)\end{array}$ & $\begin{array}{l}\text { cal BC } \\
(95.5 \%)\end{array}$ & $\begin{array}{l}\text { Archaeological } \\
\text { context, grave } \\
\text { goods }\end{array}$ & References \\
\hline VERA-3789 & $\begin{array}{l}\text { Hajdúböszörmény- } \\
\text { Ficsori-tó-dúlố }\end{array}$ & Grave $57 / 61$ & Animal bone & $5360 \pm 35$ & n.a. & $4320-4075$ & $4330-4050$ & n.a. & $\begin{array}{l}\text { Kovács and Váczi } \\
\text { 2007: } 408 \text {. }\end{array}$ \\
\hline Beta-214597 & Körösladány-Bikeri & $\mathrm{F} 8,9$ & n.a. & $5740 \pm 40$ & n.a. & $4680-4535$ & $4700-4490$ & $\begin{array}{l}\text { Posthole in inner } \\
\text { circular ditch } \\
\text { EU5-48 }\end{array}$ & $\begin{array}{l}\text { Yerkes et al. } \\
\text { 2009: } 1093 \text {. }\end{array}$ \\
\hline Beta-234310 & Körösladány-Bikeri & F30 & n.a. & $5730 \pm 40$ & n.a. & $4655-4505$ & $4690-4465$ & $\begin{array}{l}\text { Fill }(\mathrm{L} 1) \text { in middle } \\
\text { circular ditch } \\
\text { EU5-124 }\end{array}$ & $\begin{array}{l}\text { Yerkes et al. } \\
\text { 2009: } 1093 \text {. }\end{array}$ \\
\hline Beta-234308 & Körösladány-Bikeri & F29 & n.a. & $5560 \pm 40$ & n.a. & $4450-4355$ & $4465-4335$ & $\begin{array}{l}\text { Trench in lower } \\
\text { occupation level } \\
\text { EU4-103 }\end{array}$ & $\begin{array}{l}\text { Yerkes et al. } \\
\text { 2009: } 1093 \text {. }\end{array}$ \\
\hline Beta-234307 & Körösladány-Bikeri & F28 & n.a. & $5520 \pm 40$ & n.a. & $4445-4330$ & $4455-4270$ & $\begin{array}{l}\text { Bell-shaped pit fill } \\
\text { EU4-144 }\end{array}$ & $\begin{array}{l}\text { Yerkes et al. } \\
\text { 2009: } 1093 \text {. }\end{array}$ \\
\hline Beta-214595 & Körösladány-Bikeri & F5 & n.a. & $5420 \pm 40$ & n.a. & $4335-4255$ & $4355-4080$ & $\begin{array}{l}\text { West } 1 / 2 \text { bell- } \\
\text { shaped pit }(0-10 \\
\text { cm)EU4-48 }\end{array}$ & $\begin{array}{l}\text { Yerkes et al. } \\
\text { 2009: } 1093 \text {. }\end{array}$ \\
\hline Beta-234306 & Körösladány-Bikeri & F10 & n.a. & $5410 \pm 80$ & n.a. & $4350-4075$ & $4445-4040$ & $\begin{array}{l}\text { Bell-shaped pit fill } \\
\text { EU4-103 }\end{array}$ & $\begin{array}{l}\text { Yerkes et al. } \\
\text { 2009: } 1093 \text {. }\end{array}$ \\
\hline Beta-214596 & Körösladány-Bikeri & $\mathrm{F} 2$ & n.a. & $5370 \pm 40$ & n.a. & $4325-4075$ & $4335-4055$ & $\begin{array}{l}\text { Outer circular } \\
\text { ditch bottom fill } \\
\text { EU5-53 }\end{array}$ & $\begin{array}{l}\text { Yerkes et al. } \\
\text { 2009: } 1093 \text {. }\end{array}$ \\
\hline Beta-234313 & Körösladány-Bikeri & F48 & n.a. & $5370 \pm 60$ & n.a. & $4330-4070$ & $4335-4050$ & $\begin{array}{l}\text { Well, sample } 1 \\
\text { EU7-64 }\end{array}$ & $\begin{array}{l}\text { Yerkes et al. } \\
\text { 2009: } 1093 \text {. }\end{array}$ \\
\hline Beta-234314 & Körösladány-Bikeri & F48 & n.a. & $5430 \pm 50$ & n.a. & $4340-4250$ & $4365-4070$ & $\begin{array}{l}\text { Well, sample } 1 \\
\text { EU7-64 }\end{array}$ & $\begin{array}{l}\text { Yerkes et al. } \\
\text { 2009: } 1093 \text {. }\end{array}$ \\
\hline Beta-234312 & Körösladány-Bikeri & F35 & n.a. & $5380 \pm 40$ & n.a. & $4330-4170$ & $4335-4055$ & $\begin{array}{l}\text { Bell-shaped pit fill } \\
\text { EU6-46 }\end{array}$ & $\begin{array}{l}\text { Yerkes et al. } \\
\text { 2009: } 1093 \text {. }\end{array}$ \\
\hline MAMS-14249 & Male Raškovce & Grave 1 & $\begin{array}{l}\text { Homo sapiens, } \\
\text { cranium }\end{array}$ & $5427 \pm 29$ & -29.5 & $4335-4260$ & $4345-4240$ & $\begin{array}{l}\text { Maturus, E-W } \\
\text { oriented, lying on } \\
\text { the right side, } \\
4 \text { Tiszapolgár- } \\
\text { style vessel }\end{array}$ & $\begin{array}{l}\text { Brummack } \\
\text { 2015: } 5 \text {. }\end{array}$ \\
\hline
\end{tabular}

(Continued) 


\begin{tabular}{|c|c|c|c|c|c|c|c|c|c|}
\hline Lab. no. & Site & Feature & Material & $\begin{array}{l}\text { Radiocarbon } \\
\text { age (BP) }\end{array}$ & $\delta^{13} \mathrm{C}$ & $\begin{array}{l}\text { cal BC } \\
(68.2 \%)\end{array}$ & $\begin{array}{l}\text { cal BC } \\
(95.5 \%)\end{array}$ & $\begin{array}{l}\text { Archaeological } \\
\text { context, grave } \\
\text { goods }\end{array}$ & References \\
\hline Poz-33547 & $\begin{array}{l}\text { Pusztataskony-Ledence } \\
\text { Site } 1\end{array}$ & F381/S494 & Homo sapiens & $5460 \pm 40$ & $-26.1 \pm 0.5$ & $4350-4260$ & $4370-4235$ & \multirow{6}{*}{$\begin{array}{l}165 \mathrm{~cm} \text { deep, } \\
\text { round pit with } \\
\text { diameters of } 195- \\
235 \mathrm{~cm}, 48-52 \\
\text { year-old female, } \\
\text { E-W oriented, } \\
\text { lying on the left } \\
\text { side in contracted } \\
\text { position, } 3 \text { vessels, } \\
\text { animal bones } \\
\text { (hare, toad, water } \\
\text { vole, at least } 11 \\
\text { snakes, frog, } \\
\text { hedgehog) } \\
34 \text { - } 40 \text { years old } \\
\text { male, E-W } \\
\text { oriented, lying on } \\
\text { the right side in a } \\
\text { contracted } \\
\text { position, } 3 \text { vessels, } \\
\text { copper pin fragm., } \\
\text { copper dagger, } \\
\text { long flint blade, } \\
\text { stone arrowhead, } \\
\text { ochre } \\
32-38 \text { years old } \\
\text { male, E-W } \\
\text { oriented, lying on } \\
\text { the right side in a } \\
\text { contracted } \\
\text { position, } 1 \text { vessel, } \\
\text { long flint blade }\end{array}$} & \multirow{4}{*}{$\begin{array}{l}\text { Bartosiewicz et al. } \\
\text { 2013; Raczky } \\
\text { 2013; Raczky and } \\
\text { Siklósi 2013: 560, } \\
\text { table 1. }\end{array}$} \\
\hline Poz-33548 & $\begin{array}{l}\text { Pusztataskony-Ledence } \\
\text { Site } 1\end{array}$ & F381/S494 & snake bone & $5490 \pm 40$ & $-24.6 \pm 0.5$ & $4370-4265$ & $4450-4255$ & & \\
\hline Poz-33549 & $\begin{array}{l}\text { Pusztataskony-Ledence } \\
\text { Site } 1\end{array}$ & F381/S494 & $\begin{array}{l}\text { Erinaceus } \\
\quad \text { roumanicus }\end{array}$ & $5420 \pm 40$ & $-23.2 \pm 0.5$ & $4335-4255$ & $4355-4080$ & & \\
\hline Poz-33550 & $\begin{array}{l}\text { Pusztataskony-Ledence } \\
\text { Site } 1\end{array}$ & F381/S494 & $\begin{array}{l}\text { Lepus } \\
\quad \text { europaeus }\end{array}$ & $5420 \pm 40$ & $-24.0 \pm 0.5$ & $4335-4255$ & $4355-4080$ & & \\
\hline VERA-4199 & $\begin{array}{l}\text { Rákóczifalva-Bivaly-tó } \\
1 / \mathrm{c}\end{array}$ & $\begin{array}{l}\text { F140/S152, } \\
\text { grave }\end{array}$ & Homo sapiens & $5290 \pm 35$ & $-17.1 \pm 0.7$ & $4230-4045$ & $4235-3995$ & & $\begin{array}{l}\text { Csányi et al. 2010: } \\
\text { 256, 263; Raczky } \\
\text { and Siklósi 2013: } \\
\text { 560-561, table 1; } \\
\text { Zoffmann 2015: } \\
29 .\end{array}$ \\
\hline VERA-4758 & $\begin{array}{l}\text { Rákóczifalva-Bivaly-tó } \\
1 / \mathrm{c}\end{array}$ & $\begin{array}{l}\text { F144/S156, } \\
\text { grave }\end{array}$ & Homo sapiens & $5285 \pm 40$ & $-22.2 \pm 1.0$ & $4230-4040$ & $4240-3990$ & & $\begin{array}{l}\text { Csányi et al. 2010: } \\
\text { 256, 263; Raczky } \\
\text { and Siklósi 2013: } \\
\text { 560-561, table 1; } \\
\text { Zoffmann 2015: } \\
29 .\end{array}$ \\
\hline
\end{tabular}

Table 3 (Continued)

koczifalva-Bivaly-tó

$40 / \mathrm{S} 152$

VERA-4

kóczifalva-Bivaly-tó

gr/S156 
Table 3 (Continued)

\begin{tabular}{|c|c|c|c|c|c|c|c|c|c|}
\hline Lab. no. & Site & Feature & Material & $\begin{array}{l}\text { Radiocarbon } \\
\text { age (BP) }\end{array}$ & $\delta^{13} \mathrm{C}$ & $\begin{array}{l}\text { cal BC } \\
(68.2 \%)\end{array}$ & $\begin{array}{l}\text { cal BC } \\
(95.5 \%)\end{array}$ & $\begin{array}{l}\text { Archaeological } \\
\text { context, grave } \\
\text { goods }\end{array}$ & References \\
\hline VERA-4759 & $\begin{array}{l}\text { Rákóczifalva-Bivaly-tó } \\
1 / \mathrm{c}\end{array}$ & $\begin{array}{l}\text { F201/S328, } \\
\text { grave }\end{array}$ & Homo sapiens & $5415 \pm 35$ & $-22.6 \pm 1.8$ & $4330-4255$ & $4345-4175$ & $\begin{array}{l}34-38 \text { years old } \\
\text { male, E-W } \\
\text { oriented, lying on } \\
\text { the right side, } 6 \\
\text { vessels and } \\
\text { fragm., golden tip } \\
\text { of a small stick, } \\
\text { Siria-type copper } \\
\text { hammer axe, } 3 \\
\text { obsidian } \\
\text { arrowheads, } 2 \\
\text { chipped stone } \\
\text { tools, ochre, } \\
\text { animal bones }\end{array}$ & $\begin{array}{l}\text { Csányi et al. 2010: } \\
\text { 256, 263; Raczky } \\
\text { and Siklósi 2013: } \\
\text { 560-561, table 1; } \\
\text { Zoffmann 2015: } \\
29 \text {. }\end{array}$ \\
\hline VERA-4200 & $\begin{array}{l}\text { Rákóczifalva-Bivaly-tó } \\
1 / \mathrm{c}\end{array}$ & $\begin{array}{l}\text { F203/S215, } \\
\text { grave }\end{array}$ & Homo sapiens & $5380 \pm 30$ & $-16.1 \pm 1.6$ & $4325-4175$ & $4335-4070$ & $\begin{array}{l}30-36 \text { years old } \\
\text { male, E-W } \\
\text { oriented, lying on } \\
\text { the right side in a } \\
\text { contracted } \\
\text { position, } 2 \text { vessels, } \\
2 \text { flint blades }\end{array}$ & $\begin{array}{l}\text { Csányi et al. 2010: } \\
\text { 256, 263; Raczky } \\
\text { and Siklósi 2013: } \\
\text { 560-561, table 1; } \\
\text { Zoffmann 2015: } \\
29 .\end{array}$ \\
\hline VERA-4201 & $\begin{array}{l}\text { Rákóczifalva-Bivaly-tó } \\
1 / \mathrm{c}\end{array}$ & $\begin{array}{l}\text { F204/S216, } \\
\text { grave }\end{array}$ & Homo sapiens & $5450 \pm 35$ & $-16.4 \pm 1.6$ & $4345-4260$ & $4355-4245$ & $\begin{array}{l}44-53 \text { years old } \\
\text { male, E-W } \\
\text { oriented, lying on } \\
\text { the right side in a } \\
\text { contracted } \\
\text { position, } 2 \text { vessels, } \\
\text { copper awl, } 2 \text { flint } \\
\text { blades, chipped } \\
\text { stone }\end{array}$ & $\begin{array}{l}\text { Csányi et al. 2010: } \\
\text { 256, 263; Raczky } \\
\text { and Siklósi 2013: } \\
\text { 560-561, table 1; } \\
\text { Zoffmann 2015: } \\
29 .\end{array}$ \\
\hline
\end{tabular}

(Continued) 


\begin{tabular}{|c|c|c|c|c|c|c|c|c|c|}
\hline Lab. no. & Site & Feature & Material & $\begin{array}{c}\text { Radiocarbon } \\
\text { age (BP) }\end{array}$ & $\delta^{13} \mathrm{C}$ & $\begin{array}{l}\text { cal BC } \\
(68.2 \%)\end{array}$ & $\begin{array}{l}\text { cal BC } \\
(95.5 \%)\end{array}$ & $\begin{array}{l}\text { Archaeological } \\
\text { context, grave } \\
\text { goods }\end{array}$ & References \\
\hline VERA-4202 & $\begin{array}{l}\text { Rákóczifalva-Bivaly-tó } \\
1 / \mathrm{c}\end{array}$ & $\begin{array}{l}\mathrm{F} 225 / \mathrm{S} 237, \\
\text { grave }\end{array}$ & Homo sapiens & $5365 \pm 35$ & $-18.7 \pm 0.6$ & $4325-4075$ & $4330-4055$ & $\begin{array}{l}26-30 \text { years old } \\
\text { male, E-W } \\
\text { oriented, lying on } \\
\text { the right side in a } \\
\text { contracted } \\
\text { position, } 4 \text { vessels } \\
\text { and fragm., } \\
\text { copper bracelet, } \\
\text { polished stone } \\
\text { chisel, flint blade, } \\
\text { chipped stone } \\
\text { tools, animal } \\
\text { bones }\end{array}$ & $\begin{array}{l}\text { Csányi et al. 2010: } \\
\text { 256, 263; Raczky } \\
\text { and Siklósi 2013: } \\
\text { 560-561, table 1; } \\
\text { Zoffmann 2015: } \\
29 \text {. }\end{array}$ \\
\hline VERA-4762 & $\begin{array}{l}\text { Rákóczifalva-Bivaly-tó } \\
1 / \mathrm{c}\end{array}$ & $\begin{array}{l}\mathrm{F} 244 / \mathrm{S} 256 \\
\text { grave }\end{array}$ & Homo sapiens & $5400 \pm 45$ & $-21.5 \pm 0.8$ & $4335-4230$ & $4345-4065$ & $\begin{array}{l}31-40 \text { years old } \\
\text { male, E-W } \\
\text { oriented, lying on } \\
\text { the right side in a } \\
\text { contracted } \\
\text { position, } 3 \text { vessels, } \\
\text { stone blade, antler } \\
\text { tool, animal bone }\end{array}$ & $\begin{array}{l}\text { Csányi et al. 2010: } \\
\text { 263; Raczky and } \\
\text { Siklósi 2013: 560- } \\
\text { 561, table 1; } \\
\text { Zoffmann 2015: } \\
29 \text {. }\end{array}$ \\
\hline VERA-4763 & $\begin{array}{l}\text { Rákóczifalva-Bivaly-tó } \\
1 / \mathrm{c}\end{array}$ & $\begin{array}{l}\mathrm{F} 281 / \mathrm{S} 293, \\
\text { grave }\end{array}$ & Homo sapiens & $5315 \pm 40$ & $-19.6 \pm 1.6$ & $4235-4055$ & $4315-4000$ & $\begin{array}{l}\text { Maturus female?, } \\
\text { E-W oriented, } \\
\text { lying on the left } \\
\text { side in a } \\
\text { contracted } \\
\text { position, } 6 \text { vessels, } \\
\text { shell }\end{array}$ & $\begin{array}{l}\text { Csányi et al. 2010: } \\
\text { 252, 263; Raczky } \\
\text { and Siklósi 2013: } \\
\text { 560-561, table 1; } \\
\text { Zoffmann 2015: } \\
29 \text {. }\end{array}$ \\
\hline VERA-4198 & $\begin{array}{l}\text { Rákóczifalva-Bivaly-tó } \\
1 / \mathrm{c}\end{array}$ & $\begin{array}{l}\text { F137/S149, } \\
\text { grave }\end{array}$ & Homo sapiens & $5285 \pm 30$ & $-23.6 \pm 1.3$ & $4230-4040$ & $4235-3995$ & $\begin{array}{l}12-14 \text { years old } \\
\text { child, SE-NW } \\
\text { oriented, lying on } \\
\text { the left side in a } \\
\text { contracted } \\
\text { position, } 4 \text { vessels, } \\
\text { belt made of a } \\
\text { copper and } 153 \\
\text { stone beads }\end{array}$ & $\begin{array}{l}\text { Csányi et al. 2010: } \\
\text { 252, 263; Raczky } \\
\text { and Siklósi 2013: } \\
\text { 560-561, table 1; } \\
\text { Zoffmann 2015: } \\
29 \text {. }\end{array}$ \\
\hline
\end{tabular}


Table 3 (Continued)

\begin{tabular}{|c|c|c|c|c|c|c|c|c|c|}
\hline Lab. no. & Site & Feature & Material & $\begin{array}{l}\text { Radiocarbon } \\
\text { age (BP) }\end{array}$ & $\delta^{13} \mathrm{C}$ & $\begin{array}{l}\text { cal BC } \\
(68.2 \%)\end{array}$ & $\begin{array}{c}\text { cal BC } \\
(95.5 \%)\end{array}$ & $\begin{array}{l}\text { Archaeological } \\
\text { context, grave } \\
\text { goods }\end{array}$ & References \\
\hline Poz-36361 & Tiszalúc-Sarkad & Grave 2 & Homo sapiens & $5070 \pm 40$ & $-21.3 \pm 0.2$ & $3950-3800$ & $3965-3775$ & 2 silver pendants & $\begin{array}{l}\text { Patay 2005: 60-61, } \\
\text { figs 70-71; Raczky } \\
\text { and Siklósi 2013: } \\
561 \text {, table } 1 .\end{array}$ \\
\hline Poz-36363 & Tiszalúc-Sarkad & Grave 8 & Homo sapiens & $5050 \pm 40$ & $-20.9 \pm 0.2$ & $3945-3790$ & $3960-3710$ & 1 vessel & $\begin{array}{l}\text { Patay 2005: } 60 \text {, } \\
\text { figs 68-69; Raczky } \\
\text { and Siklósi 2013: } \\
\text { 561, table } 1 .\end{array}$ \\
\hline Poz-36362 & Tiszalúc-Sarkad & Grave 7 & Homo sapiens & $5020 \pm 40$ & $-21.9 \pm 0.2$ & $3940-3710$ & $3945-3700$ & 3 vessels & $\begin{array}{l}\text { Patay 2005: 59-60, } \\
\text { figs 66-67; Raczky } \\
\text { and Siklósi 2013: } \\
\text { 561, table } 1 .\end{array}$ \\
\hline Poz-36367 & Tiszapolgár-Basatanya & Grave 56 & Homo sapiens & $5480 \pm 40$ & $-16.9 \pm 0.5$ & $4365-4265$ & $4450-4250$ & $\begin{array}{l}5 \text { vessels and } \\
\text { fragments, } 5 \text { flint } \\
\text { blades, domestic } \\
\text { sow's mandible, } \\
\text { sheep bones }\end{array}$ & $\begin{array}{l}\text { Bognár-Kutzián } \\
\text { 1963: 119-121, pl. } \\
\text { 48.6, 63.7-11, } \\
\text { 66.1-3, 5-6, 121.5, } \\
\text { 9; Raczky and } \\
\text { Siklósi 2013: 558, } \\
\text { table 1. }\end{array}$ \\
\hline Poz-36364 & Tiszapolgár-Basatanya & Grave 36 & Homo sapiens & $5470 \pm 40$ & $-20.7 \pm 0.1$ & $4355-4265$ & $4445-4240$ & $\begin{array}{l}6 \text { vessels, polished } \\
\text { stone axe, snail } \\
\text { shell }\end{array}$ & $\begin{array}{l}\text { Bognár-Kutzián } \\
\text { 1963: 87-89, pl. } \\
\text { 43.1-3, 5-7, 72.6; } \\
\text { Raczky and } \\
\text { Siklósi 2013: 558, } \\
\text { table 1. }\end{array}$ \\
\hline Poz-36371 & Tiszapolgár-Basatanya & Grave 123 & Homo sapiens & $5340 \pm 40$ & $-20.6 \pm 0.2$ & $4255-4065$ & $4325-4045$ & $\begin{array}{l}5 \text { vessels and } \\
\text { fragment, stone } \\
\text { beads, flint blade, } \\
\text { bone awl, pebble, } \\
\text { goat bones }\end{array}$ & $\begin{array}{l}\text { Bognár-Kutzián } \\
\text { 1963: 203-204, pl. } \\
\text { 97.7a-b, 102.8-10, } \\
\text { 107.3-7, 109.1-4; } \\
\text { Raczky and } \\
\text { Siklósi 2013: 558, } \\
\text { table 1. }\end{array}$ \\
\hline Poz-36368 & Tiszapolgár-Basatanya & Grave 57 & Homo sapiens & $5320 \pm 40$ & $-20.4 \pm 0.5$ & $4235-4060$ & $4320-4040$ & $\begin{array}{l}6 \text { vessels, stone } \\
\text { beads }\end{array}$ & $\begin{array}{l}\text { Bognár-Kutzián } \\
\text { 1963: 121-123, pl. } \\
\text { 64.4, 67.1-2, 5-6, } \\
\text { 121.6, 11a-e; } \\
\text { Raczky and } \\
\text { Siklósi 2013: 558, } \\
\text { table 1. }\end{array}$ \\
\hline
\end{tabular}


Table 3 (Continued)

\begin{tabular}{|c|c|c|c|c|c|c|c|c|c|}
\hline \multirow[b]{2}{*}{ Poz-36372 } & \multirow[b]{2}{*}{ Tiszapolgár-Basatanya } & \multirow[b]{2}{*}{ Grave 130} & \multirow[b]{2}{*}{ Homo sapiens } & \multirow[b]{2}{*}{$5260 \pm 40$} & \multirow[b]{2}{*}{$-20 \pm 0.1$} & \multirow[b]{2}{*}{$4225-3990$} & \multirow[b]{2}{*}{$4235-3975$} & \multirow[b]{2}{*}{$\begin{array}{l}\text { bones } \\
5 \text { vessels and } \\
\text { fragments, stone } \\
\text { beads, ochre }\end{array}$} & \multirow{3}{*}{$\begin{array}{l}\text { Bognár-Kutzián } \\
\text { 1963: 209-211, pl. } \\
\text { 115.1-2, 112.4-8, } \\
\text { 122.3a-f; Raczky } \\
\text { and Siklósi 2013: } \\
\text { 559, table 1. } \\
\text { Bognár-Kutzián } \\
\text { 1963: 104-105, pl. } \\
\text { 56.3-4, 6-7; } \\
\text { Raczky and } \\
\text { Siklósi 2013: 559, } \\
\text { table 1. }\end{array}$} \\
\hline & & & & & & & & & \\
\hline Poz-36365 & Tiszapolgár-Basatanya & Grave 48 & Homo sapiens & $5190 \pm 40$ & $-19.6 \pm 0.1$ & $4040-3960$ & $4225-3820$ & $\begin{array}{l}4 \text { vessels, mussel } \\
\text { shell }\end{array}$ & \\
\hline Poz-18972 & Uivar & Grave 1 & Homo sapiens & $5440 \pm 40$ & -22.3 & $4340-4260$ & $4360-4230$ & $\begin{array}{l}41-50 \text { years old } \\
\text { male, NW-SE } \\
\text { oriented, lying on } \\
\text { the right side in a } \\
\text { crouched position, } \\
\text { no grave goods }\end{array}$ & $\begin{array}{l}\text { Schier 2013: } \\
570-574 .\end{array}$ \\
\hline Poz-18973 & Uivar & Grave 2 & Homo sapiens & $5470 \pm 40$ & -17.4 & $4355-4265$ & $4445-4240$ & $\begin{array}{l}20-25 \text { years old } \\
\text { female, NW-SE } \\
\text { oriented, lying in } \\
\text { stretched position, } \\
5 \text { vessels }\end{array}$ & $\begin{array}{l}\text { Schier 2013: } \\
571-574 .\end{array}$ \\
\hline Beta-162065 & Vésztő-Bikeri & $\mathrm{F} 2$ & n.a. & $5700 \pm 40$ & n.a. & $4585-4465$ & $4680-4455$ & $\begin{array}{l}\text { Circular pit fill } \\
\text { EU1-13 }\end{array}$ & $\begin{array}{l}\text { Yerkes et al. } \\
\text { 2009: } 1094 .\end{array}$ \\
\hline
\end{tabular}


Table 3 (Continued)

\begin{tabular}{|c|c|c|c|c|c|c|c|c|c|}
\hline Lab. no. & Site & Feature & Material & $\begin{array}{c}\text { Radiocarbon } \\
\text { age (BP) }\end{array}$ & $\delta^{13} \mathrm{C}$ & $\begin{array}{l}\text { cal BC } \\
(68.2 \%)\end{array}$ & $\begin{array}{l}\text { cal BC } \\
(95.5 \%)\end{array}$ & $\begin{array}{l}\text { Archaeological } \\
\text { context, grave } \\
\text { goods }\end{array}$ & References \\
\hline$\overline{\text { Beta-179791 }}$ & Vésztő-Bikeri & F27 & n.a. & $5620 \pm 40$ & n.a. & $4495-4370$ & $4530-4360$ & $\begin{array}{l}\text { Posthole in inner } \\
\text { circular ditch } \\
\text { EU5-6 }\end{array}$ & $\begin{array}{l}\text { Yerkes et al. } \\
\text { 2009: } 1094 \text {. }\end{array}$ \\
\hline Beta-214589 & Vésztő-Bikeri & F71 & Charcoal & $5610 \pm 40$ & n.a. & $4490-4365$ & $4520-4355$ & $\begin{array}{l}\text { Burial, near } r \text {. } \\
\text { tibia EU-7-58 }\end{array}$ & $\begin{array}{l}\text { Yerkes et al. } \\
2009: 1094 .\end{array}$ \\
\hline Beta-179784 & Vésztő-Bikeri & F13 & n.a. & $5580 \pm 50$ & n.a. & $4455-4365$ & $4505-4335$ & $\begin{array}{l}\text { Bell-shaped pit } \\
\text { (zone G) EU2-251 }\end{array}$ & $\begin{array}{l}\text { Yerkes et al. } \\
\text { 2009: } 1094 \text {. }\end{array}$ \\
\hline Beta-179785 & Vésztő-Bikeri & F13 & n.a. & $5560 \pm 50$ & n.a. & $4450-4355$ & $4495-4330$ & $\begin{array}{l}\text { Bell pit (yellow } \\
\text { clay zone) } \\
\text { EU2-271 }\end{array}$ & $\begin{array}{l}\text { Yerkes et al. } \\
\text { 2009: } 1094 \text {. }\end{array}$ \\
\hline Beta-179790 & Vésztő-Bikeri & F19 & n.a. & $5550 \pm 40$ & n.a. & $4450-4350$ & $4460-4335$ & $\begin{array}{l}\text { Outer circular } \\
\text { ditch fill EU5-3 }\end{array}$ & $\begin{array}{l}\text { Yerkes et al. } \\
\text { 2009: } 1094 \text {. }\end{array}$ \\
\hline Beta-162070 & Vésztő-Bikeri & F5 & n.a. & $5490 \pm 50$ & n.a. & $4445-4265$ & $4455-4250$ & $\begin{array}{l}\text { Possible house } \\
\text { base of plowzone } \\
\text { EU-3-4 }\end{array}$ & $\begin{array}{l}\text { Yerkes et al. } \\
\text { 2009: } 1094 \text {. }\end{array}$ \\
\hline Beta-179792 & Vésztő-Bikeri & F20 & n.a. & $5440 \pm 50$ & n.a. & $4345-4255$ & $4440-4075$ & $\begin{array}{l}\text { Inner circular } \\
\text { ditch fill EU6-6 }\end{array}$ & $\begin{array}{l}\text { Yerkes et al. } \\
\text { 2009: } 1094 .\end{array}$ \\
\hline Beta-179793 & Vésztő-Bikeri & $\mathrm{F} 21$ & n.a. & $5420 \pm 50$ & n.a. & $4340-4240$ & $4360-4070$ & $\begin{array}{l}\text { Middle circular } \\
\text { ditch fill EU6-4 }\end{array}$ & $\begin{array}{l}\text { Yerkes et al. } \\
\text { 2009: } 1094 \text {. }\end{array}$ \\
\hline Beta-214592 & Vésztő-Bikeri & F35 & n.a. & $5410 \pm 40$ & n.a. & $4330-4245$ & $4350-4075$ & $\begin{array}{l}\text { Kiln/oven in well/ } \\
\text { cistern EU8-34 }\end{array}$ & $\begin{array}{l}\text { Yerkes et al. } \\
\text { 2009: } 1094 \text {. }\end{array}$ \\
\hline Beta-214593 & Vésztő-Bikeri & F15 & n.a. & $5480 \pm 50$ & n.a. & $4370-4260$ & $4450-4240$ & $\begin{array}{l}\text { North wall trench } \\
\text { fill EU9-101 }\end{array}$ & $\begin{array}{l}\text { Yerkes et al. } \\
\text { 2009: } 1094 \text {. }\end{array}$ \\
\hline Beta-179786 & Vésztő-Bikeri & F28 & n.a. & $5540 \pm 60$ & n.a. & $4450-4340$ & $4500-4260$ & $\begin{array}{l}\text { E wall trench } \\
\text { F15, W. w.t. F4/ } \\
14 \text { EU2-284 }\end{array}$ & $\begin{array}{l}\text { Yerkes et al. } \\
\text { 2009: } 1094 \text {. }\end{array}$ \\
\hline Beta-162068 & Vésztő-Bikeri & $\mathrm{F} 4$ & n.a. & $5480 \pm 40$ & n.a. & $4365-4265$ & $4450-4250$ & $\begin{array}{l}\text { House floor level } \\
\text { EU2-37 }\end{array}$ & $\begin{array}{l}\text { Yerkes et al. } \\
\text { 2009: } 1094 \text {. }\end{array}$ \\
\hline Beta-179788 & Vésztő-Bikeri & F26 & n.a. & $5540 \pm 40$ & n.a. & $4450-4345$ & $4460-4335$ & $\begin{array}{l}\text { House F4/14 } \\
\text { north wall trench } \\
\text { EU2-337 }\end{array}$ & $\begin{array}{l}\text { Yerkes et al. } \\
\text { 2009: } 1094 .\end{array}$ \\
\hline Beta-179789 & Vésztő-Bikeri & F26 & n.a. & $5460 \pm 50$ & n.a. & $4355-4260$ & $4450-4175$ & $\begin{array}{l}\text { House } \mathrm{F} 4 / 14 \mathrm{~N} \\
\text { w.t. posthole } \\
\text { EU2-347 }\end{array}$ & $\begin{array}{l}\text { Yerkes et al. } \\
\text { 2009: } 1094 \text {. }\end{array}$ \\
\hline Beta-179783 & Vésztő-Bikeri & F14 & n.a. & $5520 \pm 50$ & n.a. & $4450-4330$ & $4465-4260$ & $\begin{array}{l}\text { House floor level } \\
\text { EU2-234 }\end{array}$ & $\begin{array}{l}\text { Yerkes et al. } \\
\text { 2009: } 1094 \text {. }\end{array}$ \\
\hline
\end{tabular}




\begin{tabular}{|c|c|c|c|c|c|c|c|c|c|}
\hline Lab. no. & Site & Feature & Material & $\begin{array}{l}\text { Radiocarbon } \\
\text { age (BP) }\end{array}$ & $\delta^{13} \mathrm{C}$ & $\begin{array}{l}\text { cal BC } \\
(68.2 \%)\end{array}$ & $\begin{array}{l}\text { cal BC } \\
(95.5 \%)\end{array}$ & $\begin{array}{l}\text { Archaeological } \\
\text { context, grave } \\
\text { goods }\end{array}$ & References \\
\hline Beta-162067 & Vésztő-Bikeri & $\mathrm{F} 4$ & n.a. & $5320 \pm 60$ & n.a. & $4235-4050$ & $4325-3990$ & $\begin{array}{l}\text { Daub layer above } \\
\text { floor level EU2-27 }\end{array}$ & $\begin{array}{l}\text { Yerkes et al. } \\
\text { 2009: } 1094 \text {. }\end{array}$ \\
\hline Beta-179782 & Vésztő-Bikeri & F14 & n.a. & $5310 \pm 50$ & n.a. & $4230-4050$ & $4320-3990$ & $\begin{array}{l}\text { Daub/cultural } \\
\text { layer above floor } \\
\text { EU2-223 }\end{array}$ & $\begin{array}{l}\text { Yerkes et al. } \\
\text { 2009: } 1094 \text {. }\end{array}$ \\
\hline Beta-162061 & Vésztő-Mágor & Unit 6-1 & Bone & $5410 \pm 70$ & n.a. & $4350-4080$ & $4370-4045$ & Block 6 & $\begin{array}{l}\text { Parkinson et al. } \\
\text { 2004: 106; Yerkes } \\
\text { et al. 2009: } 1093 .\end{array}$ \\
\hline OxA-24922 & Vinča-Belo Brdo & Grave 1 & $\begin{array}{l}\text { Homo sapiens, } \\
\text { cranium }\end{array}$ & $5451 \pm 35$ & -20.3 & $4345-4260$ & $4355-4245$ & $\begin{array}{l}20-30 \text { years old } \\
\text { female, } 3 \text { vessels }\end{array}$ & $\begin{array}{l}\text { Borić 2015: } 175- \\
176, \text { table } 1 \text {. }\end{array}$ \\
\hline OxA-24923 & Vinča-Belo Brdo & Grave 2 & $\begin{array}{l}\text { Homo sapiens, } \\
\text { cranium }\end{array}$ & $5335 \pm 34$ & -20.2 & $4240-4065$ & $4315-4045$ & $\begin{array}{l}\text { Ca. } 20 \text { years old } \\
\text { female, } 5 \text { vessels }\end{array}$ & $\begin{array}{l}\text { Borić 2015: } 175- \\
176 \text {, table } 1 .\end{array}$ \\
\hline
\end{tabular}


significantly older data which were ignored due to the probable old wood effect. Because of this incomplete information we decided not to incorporate these data into our model, not even as outliers.

In the case of Tiszapolgár-Basatanya, we used previously published dates (Raczky and Siklósi 2013). We placed the burials into the models according to Bognár-Kutzián's cultural classification (Bognár-Kutzián 1963).

The measurements of Pusztataskony-Ledence site 1 represent an unusual, extraordinary archaeological phenomenon. A 48-52-year-old woman was buried alone into a rounded pit separated from the nearby cemetery, accompanied by pottery and several animals' skeletons. We placed this grave into the Bodrogkeresztúr sequence of the model based on the pottery style (Bartosiewicz et al. 2013; Raczky 2013; Raczky and Siklósi 2013: 560, Table 1).

The two burials from the Vinča-Belo Brdo tell was built into the model as Bodrogkeresztúr graves also because of the pottery style (Borić 2015: 175-176, Table 1).

Based on the agreement index (Amodel=78.5) of this regional model, our model that treats the Tiszapolgár and Bodrogkeresztúr styles separately is stable. Based on this, the appearance of the Tiszapolgár style can be estimated to around $4435(68.2 \%) 4385 \mathrm{cal} \mathrm{BC}$ on the GHP (Appendix 2). In this model we did not take the measurements into account which date the find material typically from the top layers of $\mathrm{LN}$ tells previously described as Prototiszapolgár (Raczky and Anders 2016). The accurate dating of the LN-CA transition would require further measurements. At the same time, based on the currently available data, we can assume that the Tiszapolgár pottery style appeared on the GHP earlier than modeled here. The start boundary of this model dates rather the appearance of formal cemeteries and the scattered settlement pattern then the appearance of the pottery style. The use of the Tiszapolgár style may have ceased in around $4220(68.2 \%) 4165 \mathrm{cal} \mathrm{BC}$ (Appendix 2).

In contrast to this, the use of the Bodrogkeresztúr style may have appeared at a surprisingly early date, in $4400(68.2 \%) 4325 \mathrm{cal} \mathrm{BC}$, i.e., slightly later than the beginning of using the Tiszapolgár style. It remained in use until 4020 (68.2\%) 3930 cal BC (Appendix 2). The Difference query shows that the Bodrogkeresztúr style could appear 130 (68.2\%) 230 years earlier than the Tiszapolgár style disappeared (Figure 7).

The dating of the Hunyadihalom culture is based on merely two sites so far, but it belongs to the next period. Grave 18 in Barca-Baloty site is dated by three measurements-two made on anthropological and one on zoological samples_-with a significant 200-year difference in the BP values (Brummack 2015: 7). We took the middle value into account (MAMS-14244); both the older and the younger dates did not fit into the modeling. The beginning of the Hunyadihalom culture is estimated to be in $3970(68.2 \%) 3825 \mathrm{cal} \mathrm{BC}$, and the end in $3860(68.2 \%) 3750 \mathrm{cal} \mathrm{BC}$ (Figure 6).

As a sensitivity analysis, we also created a model that following the pottery typology, describes the sequentiality of the Tiszapolgár, transitional, and Bodrogkeresztúr find assemblages. Within this model, the measurements were arranged into three sequential Phases within one Sequence based on the pottery style. The Agreement Index of the model was 0.5. It suggests that the sequentiality of archaeological cultures and their phases that was defined from the traditional typochronological perspective and was based on the temporal change 


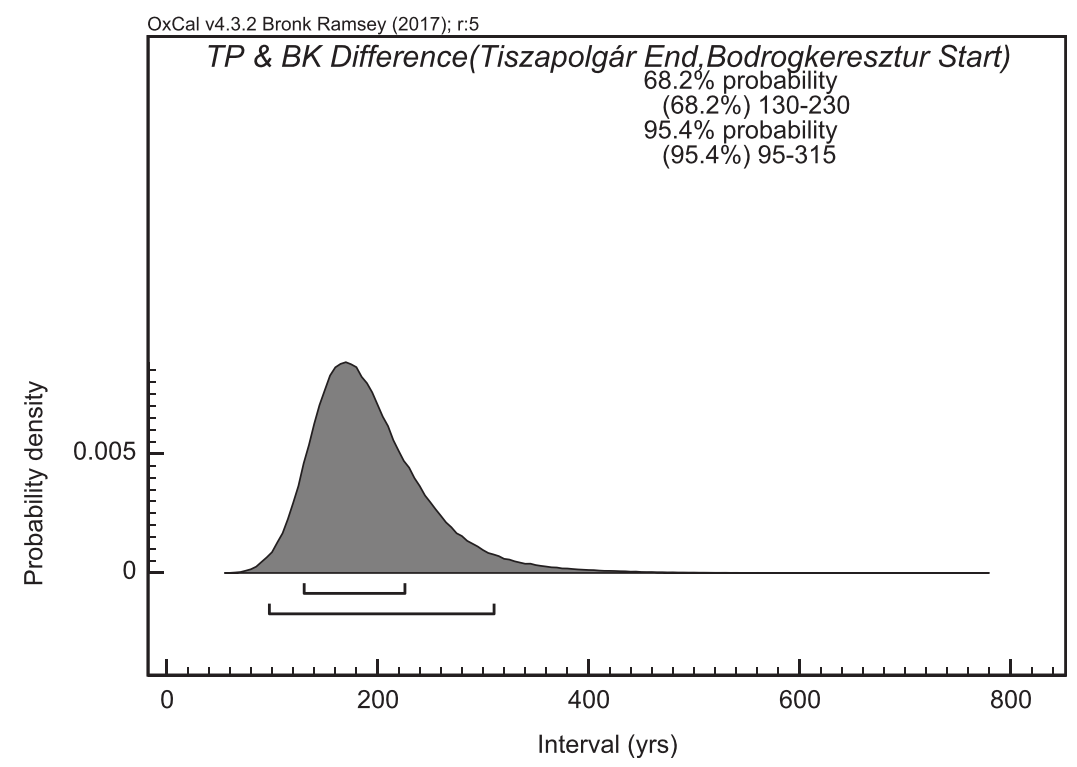

Figure 7 The difference obtained between the estimated start of the Bodrogkeresztúr style and the end of the Tiszapolgár style.

of ceramic styles in the second half of the 5th millennium BC on the GHP is very unlikely. A model that allows the temporal overlap between the use of Tiszapolgár and Bodrogkeresztúr styles seems to be much more acceptable.

\section{DISCUSSION}

We had to face methodological problems from two main directions in the case of dating the ECA and MCA on the GHP. On the one hand, the plateau on the calibration curve roughly between 4300 and 4000 cal BC makes the precise dating very difficult. We improved the accuracy by using the Bayesian analysis, and as a result of this, we were able to date CA sites much more precisely than earlier. On the other hand, the compulsory classification of find materials into archaeological cultures made the interpretation problematic.

Most of the previous analyses (except the ECA settlements in the Körös region) were based on formal cemeteries. However, this can be misleading as it reflects a ritually and intentionally selected material culture. Therefore, we thought that we could only better understand the CA of the GHP if we take the settlements into consideration by placing the same emphasis on them as on the funerals and their various types. As mentioned above, we witnessed significant differences during the stylistic examination and comparison of the finds deriving from settlements and cemeteries. We consider over-generalization as another significant distortion in the interpretation of the period. Instead of regional generalizations based on a single site, we tried to discover local, microregional diversity and variability.

Despite several recent major prehistoric dating projects, the CA of Central and Southeastern Europe is still poorly dated, and there are still only a few accurate AMS measurements performed on carefully selected samples. The fact, that there are no large, intensively used sites or multi-layered tells in this period that would provide almost unlimited potential find 
material for sampling and stratigraphic information that could be built into a Bayesian model makes the dating of this period even more difficult.

\section{Local Level}

Our bottom-up approach, starting from the local unit made it possible to examine the temporal differences in the use of pottery style comparing single sites. Although we were able to work with a significant amount of radiocarbon data, we frequently had to rely on a small number of measurements from a single site. The low number of measurements is the reason why in some cases, the site level models (e.g., Kunszentmárton-Pusztaistvánháza) provided a vast time interval. This can only be solved by further measurements.

In our regional model, we were able to estimate the start and end of the use of each site more accurately since this model assumed a relationship between measurements from different sites. This is especially important in case we only have 1-2 measurements so far. The essential difference between the two models can be found in the implicit archaeological interpretation. In the case of local models, the find material of a site was studied on its own, without taking the closer or distant sites into account. This approach allows such interpretations that, for example, the inhabitants of a particular settlement can make their own choices of the pottery style they use, and there can be more traditional and more innovative communities.

In contrast to this, when building a regional model, a relationship between the sites and the used styles is assumed; thus, the dating of one site affects the dating of the other sites. Which approach reflects reality better? It is a question of archaeological interpretation. We believe that both approaches are necessary because they represent different aspects of the life of a community.

\section{Microregional Level}

\section{Polgár Microregion}

As a result of our field walking, we could reconstruct a dense network of smaller CA settlements. However, in order to decide whether these settlements coexisted, or the apparent density was a result of increased mobility and a frequent change of settlement location, we needed a more accurate dating than the typochronological classification.

After the Bayesian modeling of the AMS data, we can see on the microregional level that the use of the Tiszapolgár style in smaller settlements and cemeteries started around 4400-4300 cal $\mathrm{BC}$, while the Bodrogkeresztúr style appeared only after 4250 cal BC (Table 2). The brief overlap between the Tiszapolgár and Bodrogkeresztúr styles in the 4200s cal BC suggests that after the appearance of the Bodrogkeresztúr style the use of the Tiszapolgár style had gradually faded into the background. Based on the available radiocarbon data, only some of the sites in the Polgár microregion might have been contemporaneous, we must count with frequent changes in the location of the CA settlements within a narrow geographical area. Based on strontium isotope evidence, Giblin et al. (2013) suggests, that compared to the LN, there is no significant increase in mobility of Tiszapolgár sites. However, this does not exclude the possibility that the communities lived here changed their residence more frequently within the microregion under discussion. 


\section{Rákóczifalva Microregion}

Based on the results of field walking surveys, the CA settlement pattern is similar to those of the Polgár and Körös microregions.

Due to the size and the span of use of the cemetery and settlement discovered at the Rákóczifalva-Bivaly-tó site $1 / \mathrm{c}$, it can be assumed that not only the inhabitants of this settlement were buried into the graveyard. In order to better understand this issue and the pottery use of nearby sites, we also conducted petrographic analyses, which confirmed this hypothesis. Although the ceramic materials from the settlement $1 / \mathrm{c}$ and the cemetery showed the highest similarity, the clay material of some pottery from the graves could be related to the raw material of the settlement pottery at site 8 (Kreiter and Pánczél 2015). This is likely to be the case for more formal cemeteries of higher grave numbers.

Within this microregion, we noticed that different ceramic styles (Tiszapolgár, Kisrétpart, and Bodrogkeresztúr) were used simultaneously at different site types.

The case of these two microregions showed that there might be differences in the pottery use even within a narrower area. Comparing these two microregions, we could see an example of differently behaving communities and different histories. For this reason, it would be a mistake to extrapolate our observations in the Rákóczifalva or the Polgár microregion on to the whole GHP.

\section{Regional Level: Dating the Early and Middle Copper Age on the Great Hungarian Plain}

On a regional level, investigating the spatial and temporal use of styles on the whole GHP, we could see the contemporaneous use of different pottery styles and the continuous spread of the Bodrogkeresztúr style. There is no doubt that the Tiszapolgár style appeared earlier than the Bodrogkeresztúr style. The Tiszapolgár style is known from ca. 4500 cal $\mathrm{BC}$, while the Bodrogkeresztúr style could appear only in 4400 (68.2\%) $4325 \mathrm{cal} \mathrm{BC}$. Based on these, we can see the simultaneous use of different pottery styles on the GHP in a given time horizon, instead of homogeneous units of archaeological cultures. The Bodrogkeresztúr style appeared beside the local variants of the Tiszapolgár style, and we can count with a $130(68.2 \%) 230$ years of contemporaneity. The cultural picture became even more colorful in the period between 4350-4250 cal BC with the appearance of the Marosdécse (Decea Mureşului)-type burial on the southern part of the GHP (Csongrád-Kettőshalom, Grave 1) (Table 3) (Dani and Horváth 2012: 75, 79, Table 6).

Although the time of the abandonment of the LN tells is mainly known from conventional measurements, AMS dates and Bayesian modeling of two tells in the Polgár microregion, Polgár-Csôszhalom and Polgár-Bosnyákdomb are now available (Raczky et al. 2015; Raczky and Anders 2016). They were inhabited until around 4500-4450 cal BC. We can notice the contemporaneous use of different ceramic styles already in these cases. Looking at the whole GHP, we can see that the cessation of the tell settlements does not coincide with the appearance of the formal cemeteries, to our present knowledge, cemeteries started only after $4400 \mathrm{cal} \mathrm{BC}$. In fact, the transformation of the settlement pattern began around 4500-4450 cal BC, at the same time when most of the tells were abandoned. According to our research in the areas of Polgár and Rákóczifalva, a network of smaller, scattered settlements could be observed in these regions, just as it was the case in the Körös region (Parkinson 2006; Gyucha et al. 2009, 2014: 276-277). However, this cannot be uniformly extrapolated to the whole GHP. 
According to our field walking results, use of the LN tells, and their surroundings in the Berettyó region did not cease at the end of the LN. These settlements were either continuously used or re-used in the ECA. Tiszapolgár-style artifacts could be found on almost all of them. There is still little radiocarbon data available from this area to model these changes similarly to the Polgár or Rákóczifalva microregions, but we can presume that changes took place with different dynamics.

Our project conducted on the tell of Berettyóúfalu-Szilhalom is an excellent example of the relation between the LN tells and ECA settlements in the Berettyó region. In 2013, in cooperation with the Romano-Germanic Commission of the German Archeological Institute, we reopened the trench of 1976, in the center of the tell. One of the primary goals of the project was to collect radiocarbon samples in order to date the use of LN tell and the following ECA. Our radiocarbon samples were selected to represent all layers from the beginning of the use of the tell until the ECA layer. Samples from the ECA were taken from animal bones from the debris of a building characterized by Tiszapolgár-style pottery. The measurements were modeled using Bayesian analysis. At the end of the LN, the use of the tell could have finished in $4515(68.2 \%) 4450 \mathrm{cal} \mathrm{BC}$, followed by a $O(68.2 \%) 50$-year period represented by a thick fill layer. Then, the ECA inhabitation could start about $4475(68.2 \%) 4400 \mathrm{cal} \mathrm{BC}$ and ended in 4460 (68.2\%) $4335 \mathrm{cal} \mathrm{BC}$ (Neumann et al. 2014: 383, figs. 18-20, 22). Compared this result with the Berettyóúffalu-BerettyólaposSertéshízlalda ECA settlement, which is located $2 \mathrm{~km}$ south of Szilhalom, we can suggest (only with caution because of the small number of AMS measurements) that the cessation of tells and the appearance of the dispersed settlement pattern could be dated somewhat later, to around 4350 cal BC.

The archaeological research traditionally identified the Tiszapolgár and Bodrogkeresztúr archaeological cultures with the regional level. Although within these cultures, based on typochronology, some spatial and chronological groups and/or phases were distinguished, the archaeological culture remained the basic analytical unit. The results of our current research show that this homogeneous unit is hard to maintain, as we can see the diversity of material culture, burial customs and settlement pattern on the microregional level on the GHP. Homogeneity appeared at most on the local level within a time interval that we can study today.

Only a few sites are known where vertical stratigraphy could be observed between Tiszapolgár and Bodrogkeresztúr finds. The most significant one is Székely-Zöldtelek which made the periodization of the whole CA on the GHP possible in the 1950s (Kalicz 1958). This site is used even nowadays as a decisive argument in the discourse on the chronology of this period (cf. Brummack 2015), ignoring the fact that only a small test trench was excavated in spits and not using a layer tracking technique. Based on this, the assumption of the homogeneous unity and succession of the Tiszapolgár and Bodrogkeresztúr cultures throughout the GHP is, in our opinion, an over-generalization and does not contradict in itself to the more accurate field observations of recent excavations.

Superposition of the Tiszapolgár and Bodrogkeresztúr finds was also documented in Crna Bara (Garašanin and Garašanin 1957). A similar situation could be observed at Pecica-Forgaci (Banat, Romania) as in Székely-Zöldtelek. An approximately $90 \mathrm{~cm}$ deep archaeological layer was excavated and divided into two layers. Both contained mostly finely decorated Bodrogkeresztúr material but also a few Tiszapolgár or Tiszapolgár-like elements (Luca 1993; Tiszapolgár elements, e.g. fig 1.1, fig 10.3). A more accurate understanding of these sites would only be possible through new fieldwork and research projects. 
Other sites around the city of Pecica provided some information on vertical superposition. At the site Pecica No. 15 Bodrogkeresztúr settlement features were discovered (wells and pits). The settlement was dated to the Bodrogkeresztúr phase although the presence of Tiszapolgár pottery shapes and plastic decoration was mentioned. On the site map, a few superpositions can be seen, but this fact is not detailed in the text (Virag 2013: Pl. II.1.). A similar superposition can be observed in Rákóczifalva-Bivaly-tó site $1 / \mathrm{c}$ where a pit was dug into one of the buildings (Figure 5). The only case of superposition from cemeteries is known from Tiszapolgár-Basatanya where two superposition were observed, one of them was a Tiszapolgár grave which was cut by a grave dated to the transitional period (Graves 56 and 57, Bognár-Kutzián 1963: 516). AMS dating of these graves confirmed their succession (Raczky and Siklósi 2013: 563).

On the contrary, no superposition could be observed at Pecica-Est where 143 graves and a few settlement features were found. Most of the pottery from the graves could be classified as Tiszapolgár although several milk jugs, heavy copper tools, and golden ornaments were also found. The settlement features, however, were undoubtedly defined as Tiszapolgár based on the pottery material (Sava et al. 2017).

As we have seen above, the separation of the Tiszapolgár and Bodrogkeresztúr finds frequently caused problems even to the followers of the traditional typochronological approach who suggested different solutions. Radiocarbon measurements and models published here provide critical new data and new arguments for the debate about the role of transitional finds and the role of the Kisrétpart group in the transformation processes. These data suggest that classic Tiszapolgár, Kisrétpart, and Bodrogkeresztúr style finds could have been used contemporaneously; they were no strict chronological phases following each other. A possible explanation for this can be the communities' different attitude towards pottery use. The makers of these vessels probably selected forms and decorations from a uniform pottery set and the observed variability of the characteristics of single sites is the result of local traditions and taste.

Another significant methodological problem is that the pottery typology of the Tiszapolgár and Bodrogkeresztúr cultures was developed almost exclusively on the basis of cemeteries as was formerly highlighted by Cs. Siklódi as well (Siklódi 1982-1983: 13). However, only deliberately selected pottery was placed into this ritual context, and there were no attempts to compare the characteristics of pottery from cemeteries with pottery assemblages of settlements. A possible reason for this is the lack of excavated settlements, on the one hand, and on the other hand, the fragmentation of the settlement pottery, which makes the building of a comprehensive typological system extremely difficult. Considering all this, we thought that an essential element of our research project would be to date and study both settlement and burial features in the light of pottery use. As a result of this complex approach, we could see that the proportion of the pottery style described as Bodrogkeresztúr is usually smaller in settlement contexts than in the find material of the cemeteries.

\section{CONCLUSION}

Relying on the strength of these findings, we could see the contemporaneous use of different pottery styles on the GHP instead of the existence of monothetic archaeological cultures. Local variants of the Tiszapolgár style, the Bodrogkeresztúr style and elements of the ochre grave complex also appeared between 4350 and 4250 cal BC. We can also see a spatial difference: the Bodrogkeresztúr style appeared firstly in the sites of the Middle Tisza 
region. Based on the new radiocarbon data, the appearance of heavy copper tools and golden ornaments can be dated to an earlier time, to approximately 4350 cal BC.

An important conclusion to be drawn from the results of our research is that the dating of a specific archaeological phenomenon and style observed at one site cannot be arbitrarily extrapolated to another site. Regional conclusions cannot be drawn from observations at a single site, and they cannot be generalized in space or time. Also, radiocarbon dating is now accurate enough to detect these differences, and there are enough radiocarbon measurements available to reveal them.

The advantage of our bottom-up approach is that we can detect minor differences on multiple levels within a region without letting them be blurred by the concept of the presumed homogeneous archaeological culture.

Based on our results, we suggest changing the terminology of the period, since the Tiszapolgár and Bodrogkeresztúr pottery styles cannot be sharply separated in time, and there is a significant overlap between them. At the same time, the use of the Hunyadihalom style is clearly different in time. Thus, we think that in the future it would be better to classify both Tiszapolgár and Bodrogkeresztúr finds to the ECA, and the Hunyadihalom finds to the MCA on the GHP.

\section{ACKNOWLEDGMENTS}

The project was funded by the Hungarian Scientific Research Fund (OTKA Grant 101062, "Chronological and spatial relations of Early and Middle Copper Age settlements, cemeteries and metal finds on the Great Hungarian Plain" PI: Zsuzsanna Siklósi). Zsuzsanna Siklósi's work was supported by the Bolyai János Research Fellowship. We are grateful to Dr. Ildikó Pap (Hungarian Natural History Museum, Department of Anthropology) for her help with the sample selection. We want to express our gratitude to Dr. Marietta Csányi, Dr. Judit Tárnoki (Damjanich János Museum, Szolnok) and Dr. Pál Raczky (Eötvös Loránd University, Institute of Archaeological Sciences) for allowing us to study the Rákóczifalva-Bivaly-tó site 1/c. We would also like to thank László Szolnoki (Déri Museum, Debrecen) for permitting us to work with the material from Berettyóújfalu-Berettyólapos-Sertéshízlalda. We are very grateful to Dr. Dušan Borić (Columbia University, Italian Academy for Advanced Studies in America) for sharing us the date from Rákóczifalva-Bivaly-tó site 1/c measured in Oxford Radiocarbon Accelerator Unit (NRCF program (NF/2010/2/3) funded by the NERC). We are grateful to Dr. Pál Raczky for the permission of using the measurements from RákóczifalvaBagi föld site 8 made in the Vienna Environmental Research Accelerator.

\section{REFERENCES}

Bankoff HA, Winter FA. 1990. The Later Aeneolithic in Southeastern Europe. American Journal of Archaeology 94(2):175-191.

Bartosiewicz L, Kovács ZsE, Farkas B. 2013. Pass the skeleton key... animals in an Early Copper Age inhumation burial from Pusztataskony-Ledence I, Hungary. In: Starnini E, editor. Unconformist archaeology. Papers in honour of Paolo Biagi. Oxford: Archaeopress. p. 77-88.
Bayliss A. 2009. Rolling out revolution: using radiocarbon dating in archaeology. Radiocarbon 51(1):123-147.

Bayliss A, Bronk Ramsey C, van der Plicht J, Whittle A. 2007. Bradshaw and Bayes: towards a timetable for the Neolithic. Cambridge Archaeological Journal Supplement 17(1):1-28.

Bayliss A, van der Plicht J, Bronk Ramsey C, McCormac G, Healy F, Whittle A. 2011. 
Towards generational time-scales: the quantitative interpretation of archaeological chronologies. In: Whittle A, Healy F, Bayliss A. editors. Gathering Time: Dating the Early Neolithic Enclosures of Southern Britain and Ireland. Oxford: Oxbow Books. p. 17-59.

Benkő L, Horváth F, Horvatinčić N, Obelić B. 1989. Radiocarbon and thermoluminescence dating of prehistoric sites in Hungary and Yugoslavia. Radiocarbon 31(3):992-1002.

Bognár-Kutzián I. 1963. The Copper Age cemetery of Tiszapolgár-Basatanya. Budapest: Archaeologia Hungarica 42.

Bognár-Kutzián I. 1969. Probleme der mittleren Kupferzeit im Karpatenbecken. Študijné Zvesti Archeologického Ústavu SAV 17:31-60.

Bognár-Kutzián I. 1972. The Early Copper Age Tiszapolgár culture in the Carpathian Basin. Budapest: Archaeologia Hungarica 48.

Bognár-Kutzián I. 1985. Contribution to the prehistoric chronology of Hungary. Mitteilungen des Archäologischen Instituts der Ungarischen Akademie der Wissenschaften 14:293-298.

Bognár-Kutzián I, Csongor É. 1987. New results of radiocarbon dating of archaeological finds in Hungary. In: Pécsi M, Csongor É, editors. The Holocene Environment in Hungary. Budapest: 131-140.

Borić D. 2015. The end of the Vinča world: modelling the Neolithic to Copper Age Transition and the notion of archaeological culture. In: Hansen S, Raczky P, Anders A, Reingruber A, editors. Neolithic and Copper Age between the Carpathians and the Aegean Sea. Chronologies and Technologies from the 6th to the 4th millennium BCE. International Workshop Budapest 2012. Berlin: Archäologie in Eurasien 31. p. 167-227.

Bronk Ramsey C. 2009a. Bayesian analysis of radiocarbon dates. Radiocarbon 51(1):337-360.

Bronk Ramsey C. 2009b. Dealing with outliers and offsets in radiocarbon dating. Radiocarbon 51(3):1023-1045.

Bronk Ramsey C. 2017. Methods for summarizing radiocarbon datasets. Radiocarbon 59(6):18091833.

Brummack S. 2015. New Radiocarbon Dates from Eastern Slovakia. The Cases of Malé Raškovce and Barca Baloty. In: Hansen S, Raczky P, Anders A, Reingruber A, editors. Neolithic and Copper Age between the Carpathians and the Aegean Sea. Chronologies and Technologies from the 6th to the 4th Millennium BCE. International Workshop Budapest 2012. Berlin: Archäologie in Eurasien 31. p. 1-19.

Buck CE, Cavanagh WG,Litton CD. 1996. Bayesian approach to interpreting archaeological data. Chichester: John Wiley \& Sons.

Chapman J. 2000. Tension at funerals. Microtradition analysis in later Hungarian prehistory. Budapest: Archaeolingua Series Minor 14.
Csalog Zs. 1961. A jászberény-borsóhalmi rézkori temető és lakótelep I-II. Jászkunság 7:53-8, $144-150$.

Csányi M. 2007. Rákóczifalva-Bivaly-tó 1. lelőhely. Régészeti kutatások Magyarországon 2006: 259-260.

Csányi M, Raczky P, Tárnoki J. 2010. Das kupferzeitliche Gräberfeld von RákóczifalvaBagi-föld in Ungarn. Das Altertum 55:241-270.

Csedreki L, Dani J, Kis-Varga M, Daróczi L, Sándorné Kovács J. 2010. A hencidai aranykincs interdiszciplináris vizsgálatai (Új szempontok, új eredmények). Der Schatz von Hencida. A Debreceni Déri Múzeum Évkönyve 82:35-52.

Dani J, Horváth T. 2012. Ôskori kurgánok a magyar Alföldön. A Gödörsíros (Jamnaja) entitás magyarországi kutatása az elmúlt 30 év során. Áttekintés és revízió. Budapest: Archaeolingua.

Diaconescu D. 2014. Considerations concerning the chronology of the early Copper Age Tiszapolgár culture. Praehistorische Zeitschrift 89(2):219-241.

Ecsedy I. 1974. A new item relating the connections with the East in the Hungarian Copper Age (a Marosdécse type grave in Csongrád). A Móra Ferenc Múzeum Évkönyve 1971(2):9-17.

Forenbaher S. 1993. Radiocarbon dates and absolute chronology of the central European Early Bronze Age. Antiquity 67:235-256.

Garašanin MV and Garašanin D. 1957. Praistorisko naselje Crnoj Bari (L'habitat prehistorique de Crna Bara). Rad Vojvodanskih Muzeja 6:199218.

Giblin JI, Yerkes RW 2016. Diet, dispersal and social differentiation during the Copper Age in eastern Hungary. Antiquity 90(349):81-94.

Giblin JI, Knudson KJ, Bereczki Zs, Pálfi Gy, Pap I. 2013. Strontium isotope analysis and human mobility during the Neolithic and Copper Age: a case study from the Great Hungarian Plain. Journal of Archaeological Science 40: 227-239.

Gyucha A, Parkinson WA, Yerkes RW. 2009. A multiscalar approach to settlement pattern analysis: the transition from the Late Neolithic to the Early Copper Age on the Great Hungarian Plain. In: Thurton TL, Salisbury RB, editors. Reimagining regional analyses: the archaeology of spatial and social dynamics. Newcastle: Cambridge Scholars Publishing 100-129.

Gyucha A, Parkinson WA, Yerkes RW. 2014. The Transition from the Late Neolithic to the Early Copper Age: Multidisciplinary Investigations in the Körös Region of the Great Hungarian Plain. In: Schier W, Draşovean F, editors. The Neolithic and Eneolithic in Southeast Europe. New approaches to dating and cultural dynamics in the 6th to 4th millennium BC. Berlin: Prähistorische Archäologie in Südosteuropa 28. p. 273-296. 
Hajdú Zs. 2007. Rituális gödrök a Kárpát-medencében a Kr. e. 6000-3600 közötti időszakban $[\mathrm{PhD}$ thesis]. Eötvös Loránd University. http://www. doktori.hu/index.php?menuid $=193 \&$ vid $=8277$

Hajdú Zs, Nagy EGy. 1999. Rövid jelentés az M3-as autópálya Hajdú-Bihar megyei szakaszán azonosított régészeti lelőhelyeken 1993-1998 között végzett munkálatokról. Kurzer Bericht über die auf den an der Strecke der Autobahn M3 im Komitat Hajdú-Bihar identifizierten archäologischen Fundorten ausgeführten Arbeiten zwischen 1993-1998. A Debreceni Múzeum Évkönyve 1997-1998: 143-154.

Hertelendi E, Kalicz N, Raczky P, Horváth F, Veres M, Svingor É, Futó I, Bartosiewicz L. 1995. Reevaluation of the Neolithic in Eastern Hungary based on calibrated dates. Radiocarbon 37(2): 239-245.

Hillebrand J. 1929. A pusztaistvánházi korarézkori temető. Das frühkupferzeitliche Gräberfeld von Pusztaistvánháza. Budapest: Archaeologia Hungarica 4.

Horváth F. 2005. Gorzsa. Előzetes eredmények az újkőkori tell 1978 és 1996 közötti feltárásából. Gorzsa. Preliminary results of the excavation of the Neolithic tell between 1978-1996. In: Bende L, Lôrinczy G, editors. Hétköznapok vénuszai. Hódmezővásárhely: Móra Ferenc Múzeum. p. $51-83$.

Horváth F. 2014. Questions relating to the ProtoTiszapolgár Period in South-Eastern Hungary. Main issues and present state of research. In: Schier W, Draşovean F, editors. The Neolithic and Eneolithic in Southeast Europe. New approaches to dating and cultural dynamics in the 6th to 4th millennium BC. Berlin: Prähistorische Archäologie in Südosteuropa 28. p. 297-318.

Kalicz N. 1958. Rézkori sztratigráfia Székely község határában. Copper Age stratigraphy in the outskirts of the village Székely. Archaeologiai Értesítő 85:3-6.

Kalicz N. 1979-80. Újabb adatok a rézkori hunyadihalmi csoport időrendjéhez. Neue Beiträge zur Chronologie der kupferzeitlichen Hunyadihalom-Gruppe. A Szolnok Megyei Múzeumok Évkönyve:43-58.

Kalicz N. 1988a. Kultúraváltozások a korai és középsô rézkorban a Kárpát-medencében. Culture changes in the Carpathian Basin during the Late Neolithic and Copper Age. Archaeologiai Értesítő 114-115:3-15.

Kalicz N. 1988b. The new results of the investigation on the Hungarian Copper Age. Rassegna di Archeologia 7:75-103.

Kalicz N. 1992. A legkorábbi fémleletek DélkeletEurópában és a Kárpát-medencében az i. e. 6-5. évezredben. The oldest metal finds in Southeastern Europe and the Carpathian Basin from the 6th to 5th millennia BC. Archaeologiai Értesítő 119:3-13.
Kalicz N, Raczky P. 1984. Preliminary Report on the 1977-82 Excavations at the Neolithic and Bronze Age tell settlement at Berettyóújfalu-Herpály. Part I: Neolithic. Acta Archaeologica Academiae Scientiarum Hungaricae 36:85-136.

Kalicz N, Raczky P. 1987. The Late Neolithic of the Tisza region. A survey of recent archaeological research. In: Tálas L, Raczky $\mathrm{P}$, editors. The Late Neolithic of the Tisza region. BudapestSzolnok: Directorate of the Szolnok County Museums. p. 11-30.

Kovács K, Váczi G. 2007. The cemetery of the Early Copper Age Tiszapolgár culture at Hajúböszörmény-Ficsori-tó-dúlő. In: Kozłowski JK, Raczky P, editors. The Lengyel, Polgár and related cultures in the Middle/Late Neolithic in Central Europe. Kraków-Budapest: The Polish Academy of Arts and Sciences and Eötvös Loránd University Institute of Archaeological Sciences. p. 397-409.

Kreiter A, Pánczél P. 2015. Rákóczifalva 8. sz. telep és Rákóczifalva $1 / \mathrm{C}$ telep és temető kerámiáinak petrográfiai vizsgálata. Unpublished research report.

Luca SA. 1993. Observaţii privind faza clasică a Bodrogkeresztúr in România. Aşezarea de la Pecica-Forgaci (judeţul Arad). Analele Banatului Seria Noua Arheologie-Istorie 2: 49-84.

Marcsik A. 1974. Data of the Copper Age anthropological find of Bárdos-Farmstead at Csongrád-Kettőshalom. A Móra Ferenc Múzeum Évkönyve 1971-72(2):19-27.

Neumann D, Siklósi Zs, Scholtz R, Szilágyi M. 2014. Preliminary report on the first season of fieldwork in Berettyóújfalu-Szilhalom. Dissertationes Archaeologicae 3(2):377-403.

Neustupný E. 1968. Absolute chronology of the Neolithic and Aeneolithic periods in central and south-eastern Europe. Slovenská Archeológia 16:19-60.

Neustupný E. 1969. Absolute chronology of the Neolithic and Aeneolithic Periods in central and south-eastern Europe II. Archeologické Rozhledy 16(1):783-809.

Parkinson WA. 2006. The social organisation of Early Copper Age tribes on the Great Hungarian Plain. Oxford: British Archaeological Reports International Series 1573 .

Parkinson WA, Yerkes RW, Gyucha A. 2004. The transition from the Neolithic to the Copper Age: excavations at Vésztő-Bikeri, Hungary, 20002002. Journal of Field Archaeology 29:101-21.

Patay P. 1959. Kupferzeitliches Gräberfeld in Polgár am Bacsókert genannten Hügel. Acta Archaeologica Academiae Scientiarum Hungaricae 9:141-54.

Patay P. 1961. A bodrogkereszturi kultura temetői. Budapest: Régészeti Füzetek 2(10).

Patay P. 1974. Die hochkupferzeitliche Bodrogkeresztur-kultur. Bericht der Römisch-Germanischen Komission 55:3-71. 
Patay P. 1978. A tiszavalk-tetesi rézkori temetô és telep. Kupferzeitliches Gräberfeld und Siedlung von Tiszavalk-Tetes. Folia Archaeologica 29:21-58.

Patay P. 1979. A Tiszavalk-tetesi rézkori temetô és telep. Kupferzeitliches Gräberfeld und Siedlung von Tiszavalk-Tetes. Folia Archaeologica 30:27-53.

Patay P. 1984. Kupferzeitliche Meißel, Beile und Äxte, Ungarn. München: Prähistorische Bronzefunde IX.15.

Patay P. 2005. Kupferzeitliche Siedlung von Tiszalúc. Budapest: Inventaria Praehistorica Hungariae 11.

Patay P. 2008. A bodrogkeresztúri kultúra belső időrendjéről. Über die innere Chronologie der Bodrogkeresztúr-Kultur. Archaeologiai Értesítő 133:21-48.

Raczky P. 1988. A Tisza-vidék kulturális és kronológiai kapcsolatai a Balkánnal és az Égeikummal a neolitikum, rézkor időszakában. Szolnok: Szolnok Megyei Múzeumok Igazgatósága and Eötvös Loránd Tudományegyetem Régészeti Tanszék.

Raczky P. 1991. New Data on the Southern Connections and Relative Chronology of the „Bodrogkeresztúr-Hunyadi halom” Complex. In: Lichardus J, editor. Die Kupferzeit als historische Epoche. Saarbrücker Beiträge zur Altertumskunde 55:329-346.

Raczky P. 1999. Goldfunde aus der Kupferzeit. Die Anfänge der Metallurgie im Karpatenbecken. In: Raczky P, Kovács T, editors. Prähistorische Goldschätze aus dem Ungarischen Nationalmuseum. Budapest: Ungarischen Nationalmuseum and Institut für Archäologie der Eötvös-Loránd-Universität. p. 17-34.

Raczky P. 2013. Remains of a special "personality" from the Copper Age of the Eastern Carpathian Basin. In: Starnini E, editor. Unconformist archaeology. Papers in honour of Paolo Biagi. Oxford: BAR International Series 2528. p. 65-75.

Raczky P. 2018. A complex monument in the making at the Late Neolithic site of Polgár-Csőszhalom (Hungary). In: Bács TA, Bollók Á, Vida T, editors. Across the Mediterranean - along the Nile. Studies in Egyptology, Nubiology and Late Antiquity dedicated to László Török on the occasion of his 75th birthday. Volume 1. Budapest: Archaeolingua. p. 15-60.

Raczky P, Anders A. 2016. Polgár-Bosnyákdomb, a Late Neolithic tell-like settlement on Polgár island (NE Hungary). Preliminary results of the investigations. Folia Quaternaria 84:99-122.

Raczky P, Siklósi Zs. 2013. Reconsideration of the Copper Age chronology of the eastern Carpathian Basin: a Bayesian approach. Antiquity 87(336):555-573.

Raczky P, Anders A, Nagy EGy, Kriveczky B, Hajdú Zs, Szalai T. 1997. Polgár-Nagy Kasziba. Rézkori sírok a Kr. e. V. évezredból. Polgár-Nagy Kasziba. Copper age burials from the last 5th
Milennium B.C. In: Raczky $\mathrm{P}$, Kovács T, Anders A, editors. Utak a múltba - Az M3-as autópálya régészeti leletmentései. Paths into the Past. Rescue excavations on the M3 motorway. Budapest: Magyar Nemzeti Múzeum and ELTE Régészettudományi Intézet. p. 47-50.

Raczky P, Anders A, Siklósi Zs. 2014. Trajectories of Continuity and Change between the Late Neolithic and the Copper Age in Eastern Hungary. In: Schier W, Draşovean F, editors. The Neolithic and Eneolithic in Southeast Europe. New approaches to dating and cultural dynamics in the 6th to 4th Millennium BC. Berlin: Prähistorische Archäologie in Südosteuropa 28. p. 319-346.

Raczky P, Anders A, Sebők K, Csippán P, Tóth Zs. 2015. The Times of Polgár-Csőszhalom. Chronologies of Human Activities in a Late Neolithic Settlement in Northeastern Hungary. In: Hansen S, Raczky P, Anders A, Reingruber A, editors. Neolithic and Copper Age between the Carpathians and the Aegean Sea. Chronologies and Technologies from the 6th to the 4th Millennium BCE. International Workshop Budapest 2012. Berlin: Archäologie in Eurasien 31. p. 21-48.

Reimer PJ, Bard E, Bayliss A, Beck JW, Blackwell PG, Bronk Ramsey C, Buck CE, Cheng H, Edwards RL, Friedrich M, Grootes PM, Guilderson TP, Haflidason H, Hajdas I, Hatté Ch, Heaton TJ, Hoffmann DL, Hogg AG, Hughen KA, Kaiser KF, Kromer B, Manning SW, Niu M, Reimer RW, Richards DA, Scott EM, Southon JR, Staff RA, Turney CSM, van der Plicht J. 2013. IntCal13 and Marine13 radiocarbon age calibration curves $0-50,000$ years cal BP. Radiocarbon 55(4):1869-1887.

Renfrew C. 1969. The autonomy of the South-East European Copper Age. Proceedings of the Prehistoric Society 35:12-47.

Sava V, Mărginean F, Ursutiu A. 2017. The Eneolithic cemetery in Pecica "Est" (Arad County). Ziridava Studia Archaeologica 31:55-68.

Schier W. 2013. An antiquarian's grave? Early Tiszapolgár burials in the Late Vinča Tell Site of Uivar (Romania). In: Anders A, Kulcsár G, editors. Moments in time. Papers presented to Pál Raczky on his 60th birthday. Budapest: Ôsrégészeti Tanulmányok I/Prehistoric Studies I. p. $569-577$.

Siklódi Cs. 1982-1983. Kora rézkori település Tiszaföldváron. An Early Copper Age settlement at Tiszaföldvár. Szolnok Megyei Múzeumi Évkönyv. p. 11-31.

Siklósi Zs, Szilágyi M. 2019. New data on the provenance of copper finds from the EarlyMiddle Copper Age of the Great Hungarian Plain. Archaeological and Anthropological Sciences 11: 5275-5285. doi: 10.1007/s12520-019-00867-8. 
Šiška S. 1964. Pohrebisko tiszapolgárskej kultúry v Tibave. Slovenská Archaeologica 12(2):293-356.

Šiška S. 1968. Tiszapolgárska kultúra na Slovensku. Die Tiszapolgár-Kultur in der Slowakei. Slovenská Archaeologica 16(1):61-175.

Sofaer Derevenski J. 1997. Age and gender at the site of Tiszapolgár-Basatanya, Hungary. Antiquity 71:875-889.

Sofaer Derevenski J. 2000. Rings of life: the role of early metalwork in mediating the gendered life course. World Archaeology 31(3):389-406.

Solnay E. 2018. Early Copper Age graves from PolgárNagy-Kasziba. Dissertationes Archaeologicae 3(6):179-216.

Szilágyi M. 2015. Kora rézkori településszerkezet a Közép-Tisza-vidéken [PhD thesis]. Eötvös Loránd University.

Virag C. 2013. Archaeological discoveries from Pecica belonging to the Bodrogkeresztúr culture. Ephimeris Napocensis 23:177-196.

Virág Zs. 2010. Ringanhänger und Goldscheiben. Verbreitung und Bedeutung. In: Lichter C, editor. Jungsteinzeit im Umbruch. Die "Michelsberger Kultur" und Mitteleuropa vor 6000 Jahren. Karlsruhe: Badischen Landesmuseum Karlsruhe. p.212-217.

Vizdal J. 1977. Tiszapolgárske pohrebisko vo Vel'kých Raškovciach. Košice: Vydalo Východoslovenské vydavatel'stvo.
Vörös I. 1986. Animal remains from the funeral ceremonies in the Middle Copper Age cemetery at Tiszavalk-Tetes. Folia Archaeologica 37:75-97.

Yerkes RW, Gyucha A, Parkinson W. 2009. A multiscalar approach to modeling the end of the Neolithic on the Great Hungarian Plain using calibrated radiocarbon dates. Radiocarbon 51(3):1071-1109.

Zoffmann Zs. 1980. Eine Übersicht über das anthropologische Material der neolithischen und kupferzeitlichen Kulturen im Karpatenbecken. Alba Regia 18:9-29.

Zoffmann Zs. 1986. Das anthropologische Material des kupferzeitlichen Gräberfeldes von Tiszavalk-Tetes. A Tiszavalk-tetesi rézkori temető embertani anyaga. Folia Archaeologica 37:47-74.

Zoffmann Zs. 2004. Újabb őskori embertani leletek Kelet-Magyarországról. New Prehistoric anthropological finds from East Hungary. A Debreceni Déri Múzeum Évkönyve:83-94.

Zoffmann Zs. 2011. A bodrogkeresztúri kultúra népességének Kárpát-medencei Penrose-kapcsolatai - Embertani lelet RákóczifalvaBivaly-tó lelőhelyrôl. Anthropologiai Közlemények 52:77-84.

Zoffmann Zs. 2015. A Rákóczifalva-Bivaly-tó, Bagiföld I. lelőhelyen feltárt rézkori temetô embertani adatai. Anthropological data of the Copper Age cemetery at Rákóczifalva-Bivaly-tó, Bagi föld 1. Anthropologiai Közlemények 56:27-42. 


\section{APPENDIX 1}

Probability distributions of radiocarbon dates from ECA and MCA sites handling the sites separately. The square brackets on the left side along with the OxCal keywords exactly define the model.

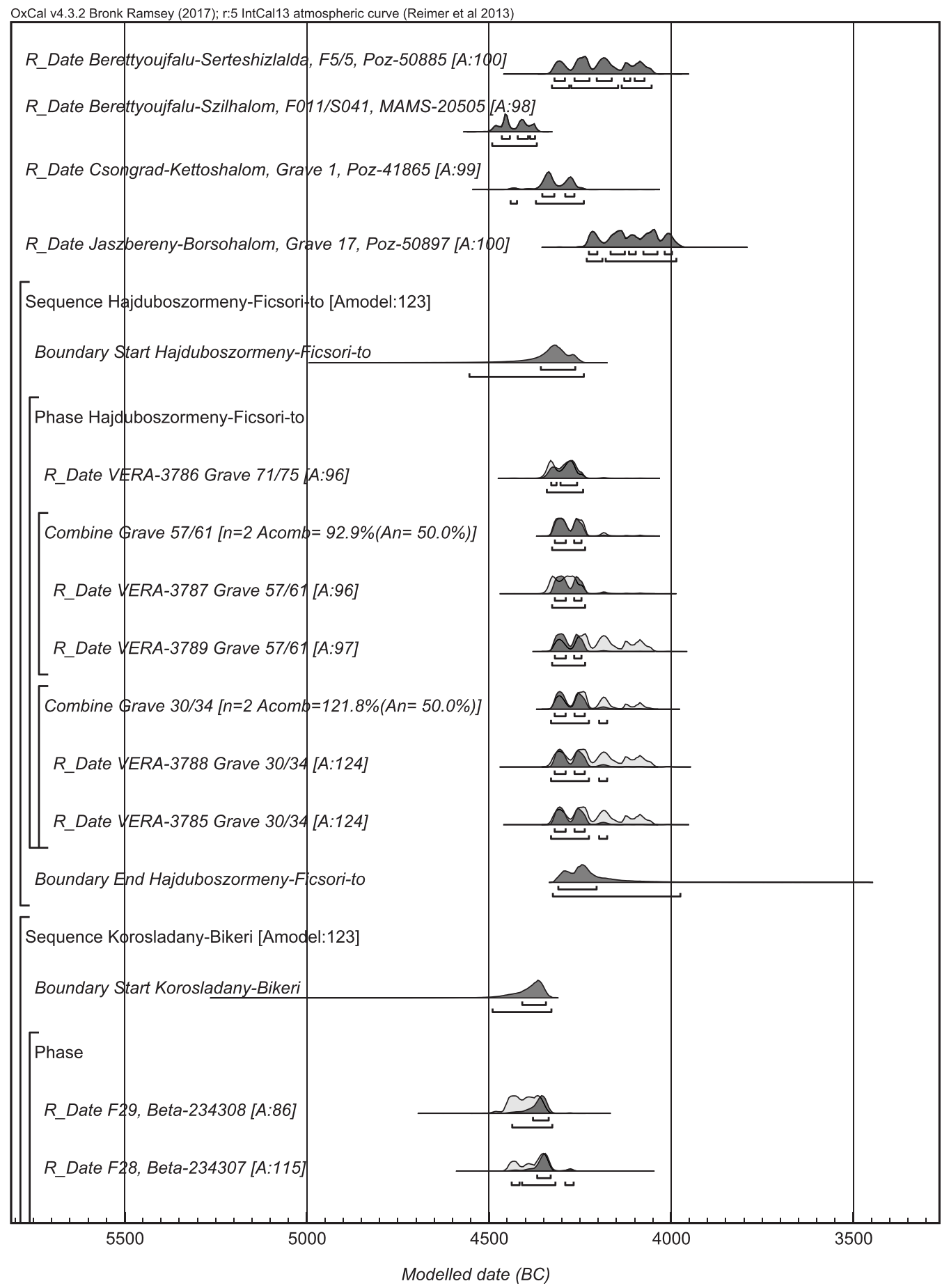




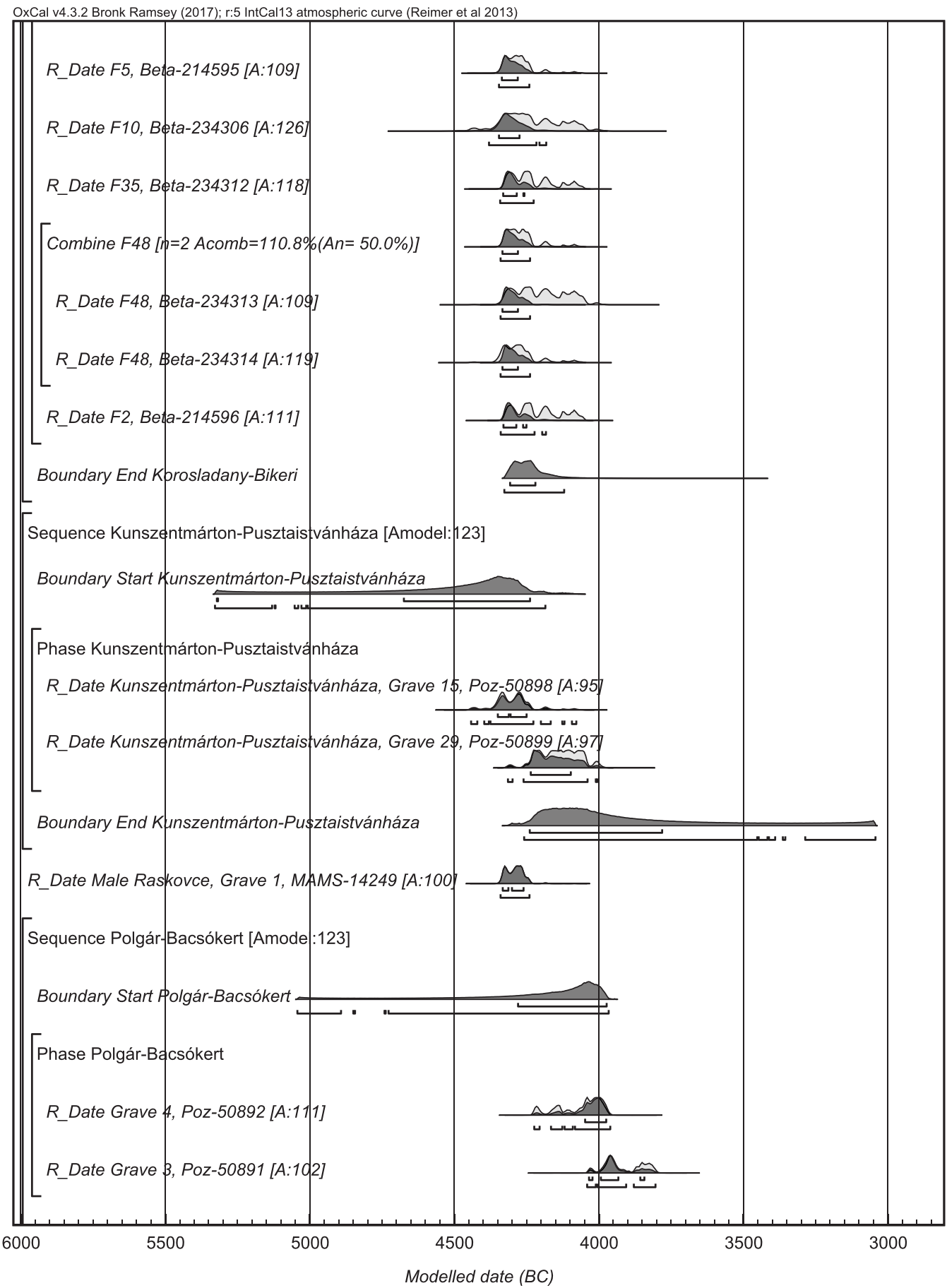


OxCal v4.3.2 Bronk Ramsey (2017); r:5 IntCal13 atmospheric curve (Reimer et al 2013)

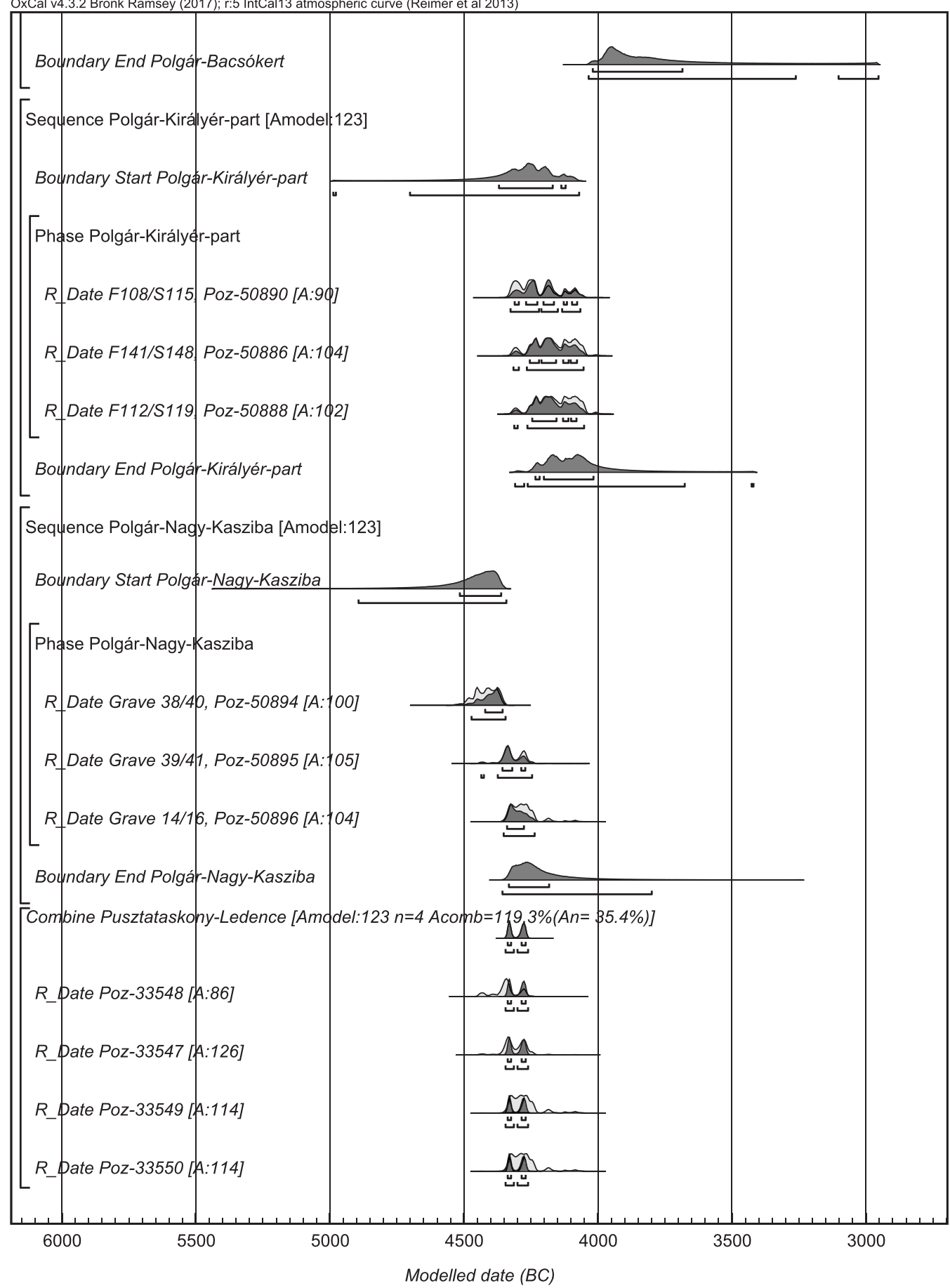




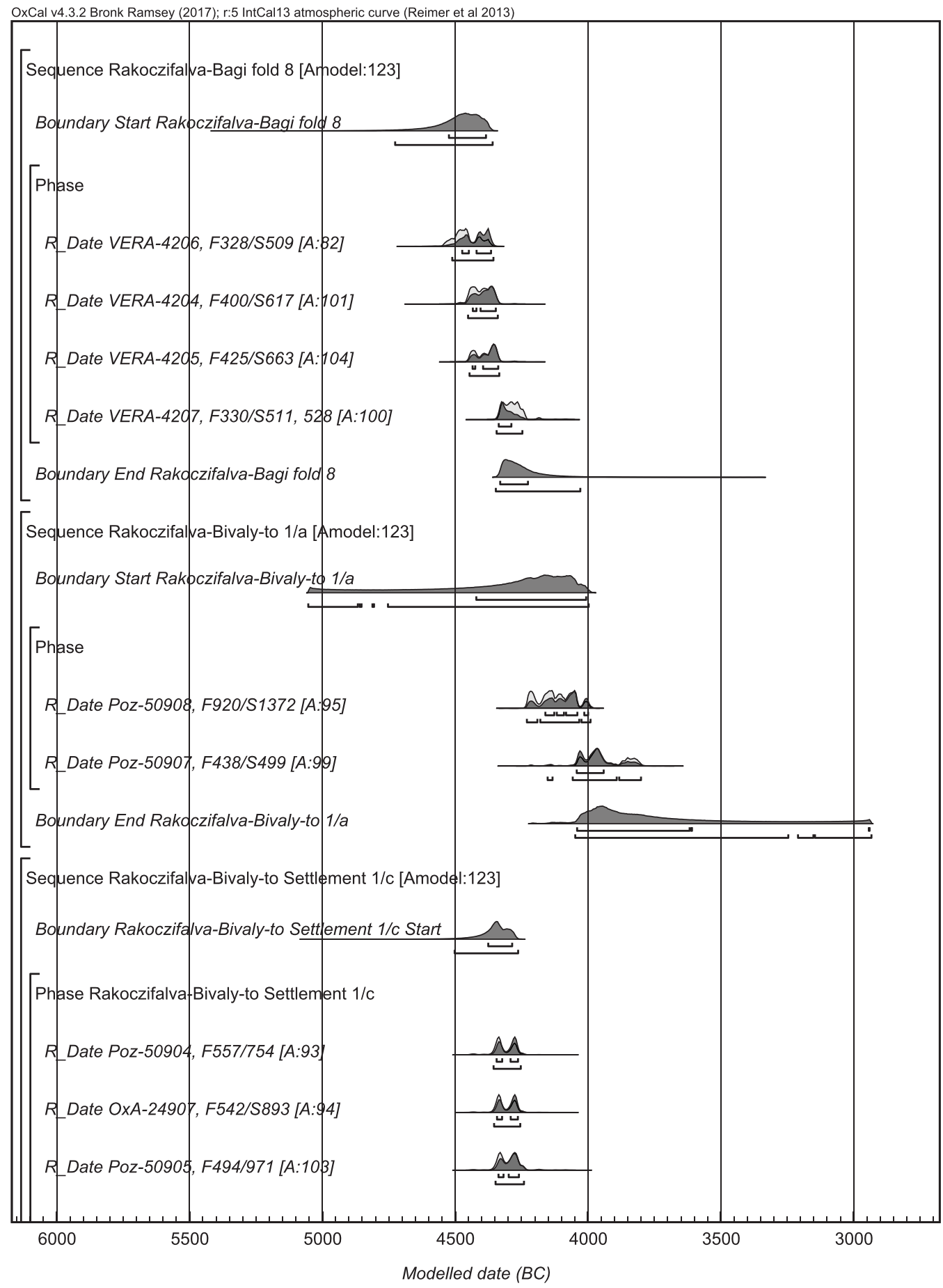




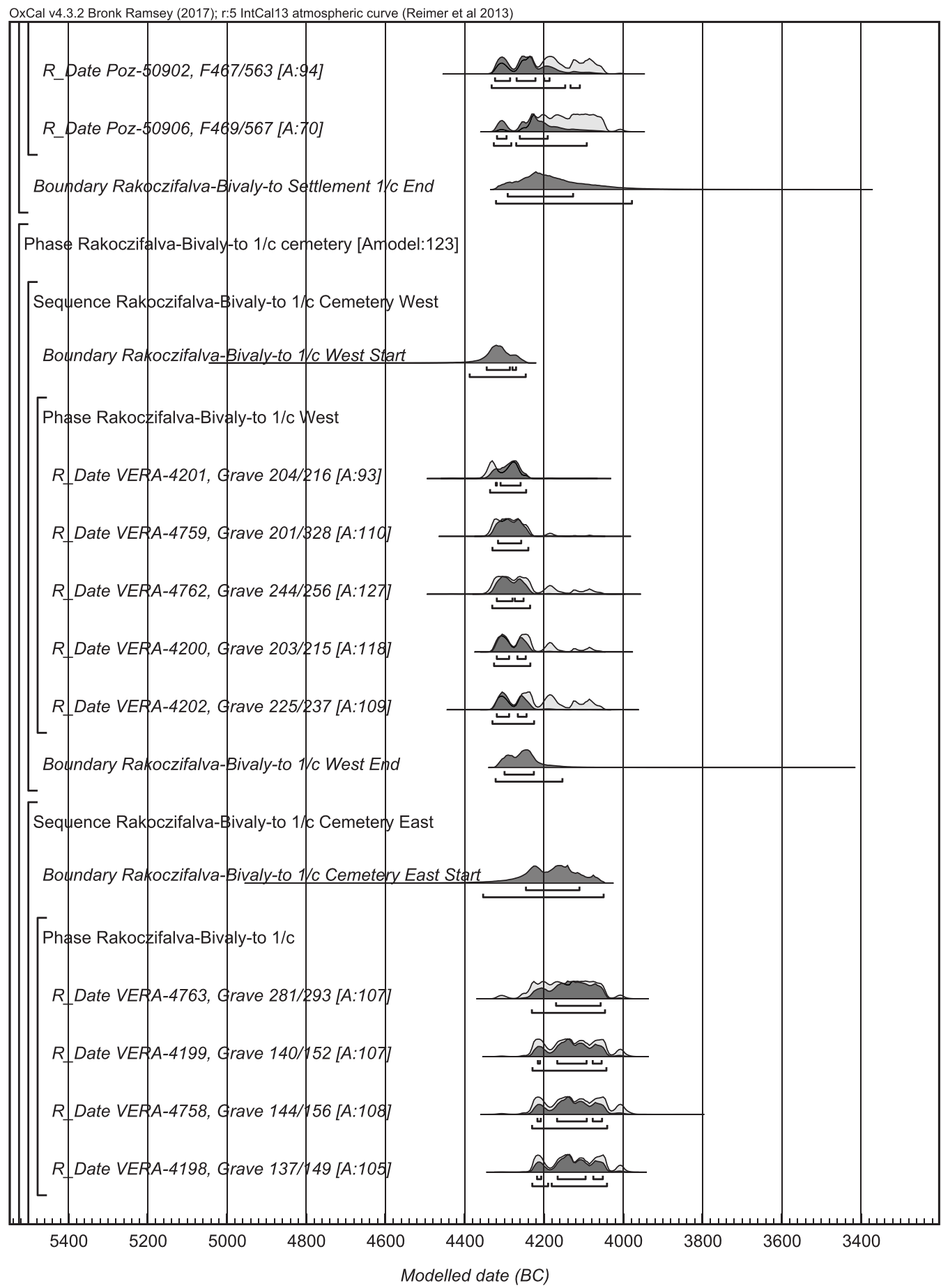




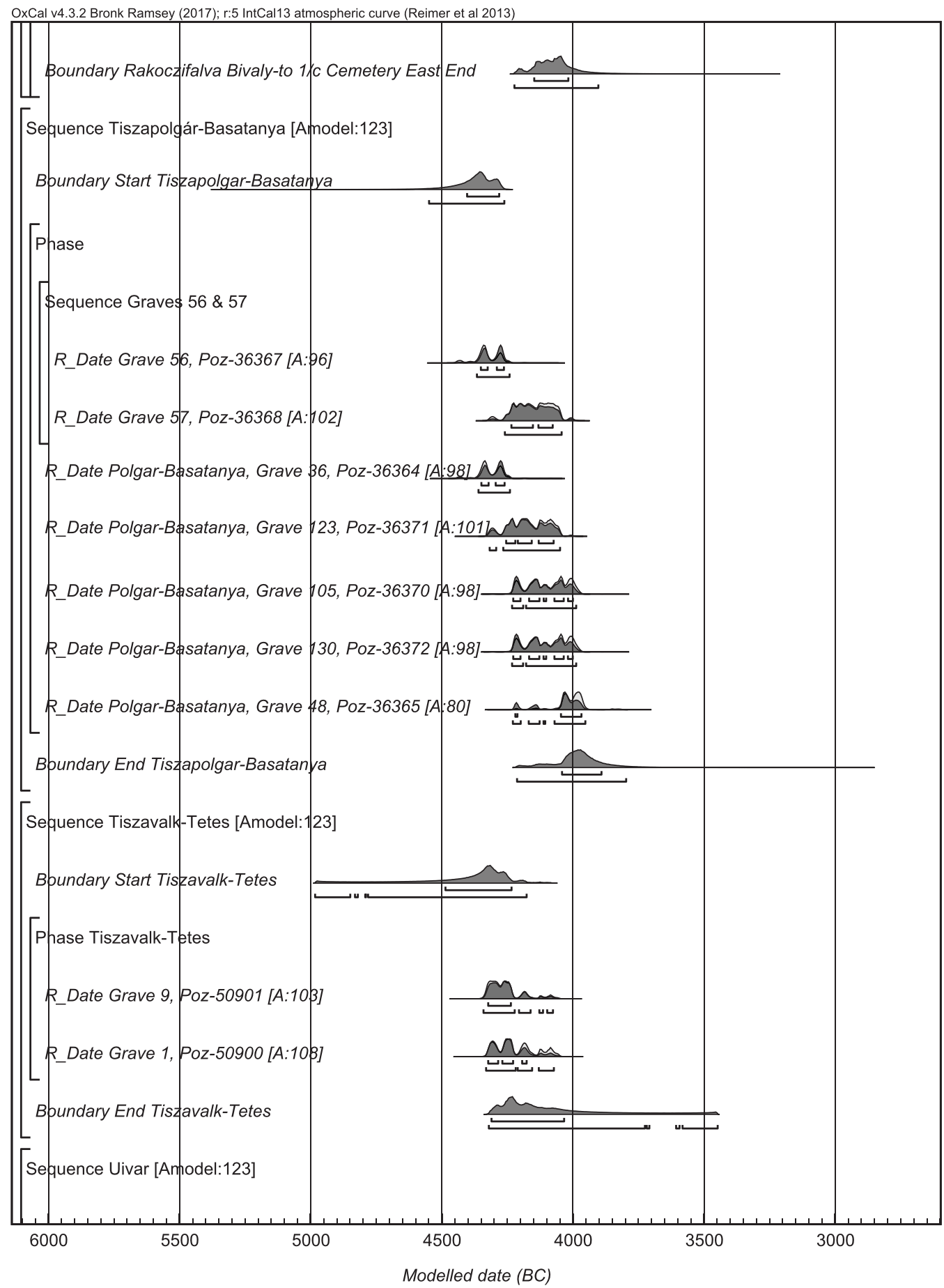


OxCal v4.3.2 Bronk Ramsey (2017); r:5 IntCal13 atmospheric curve (Reimer et al 2013)

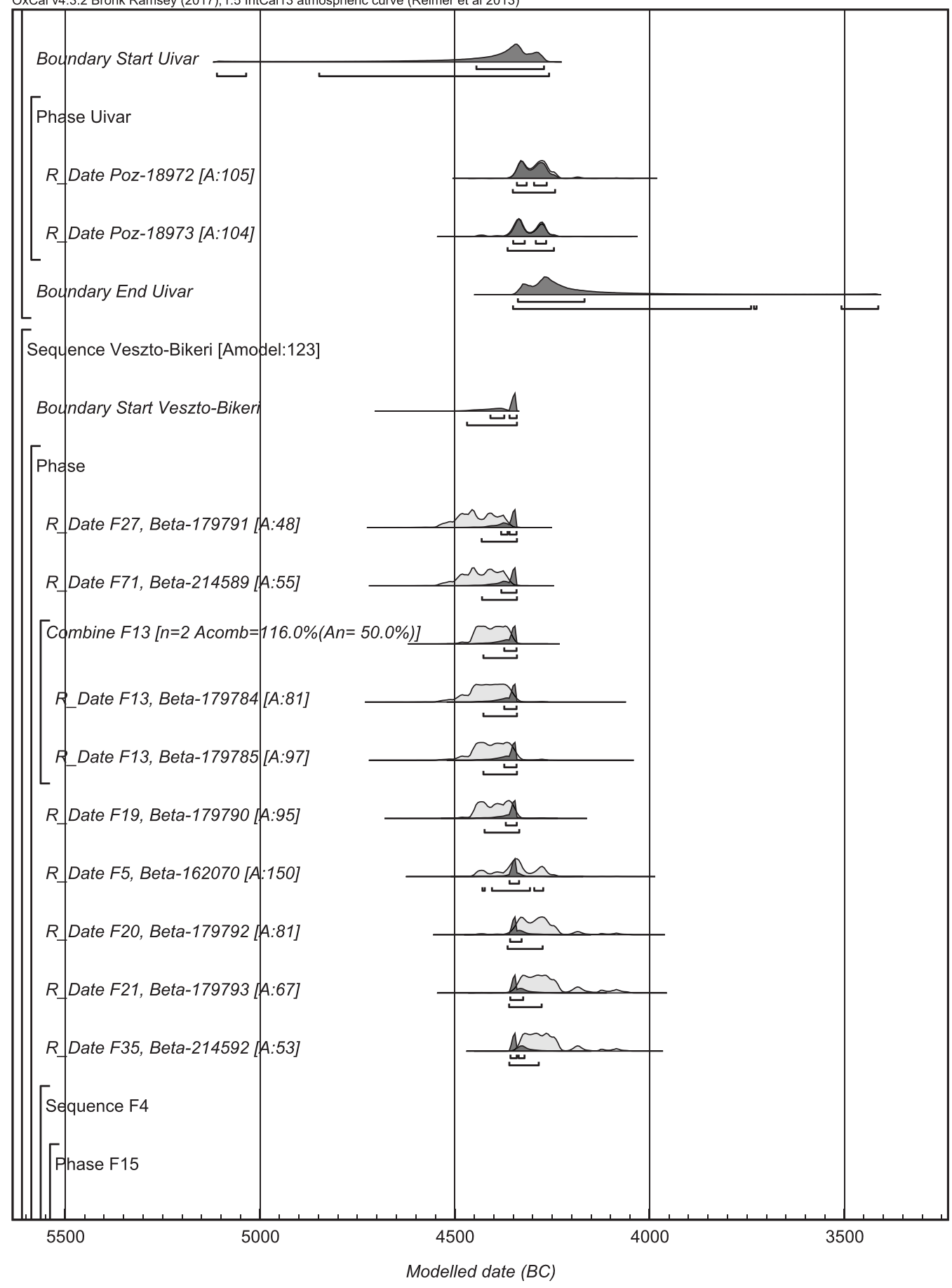




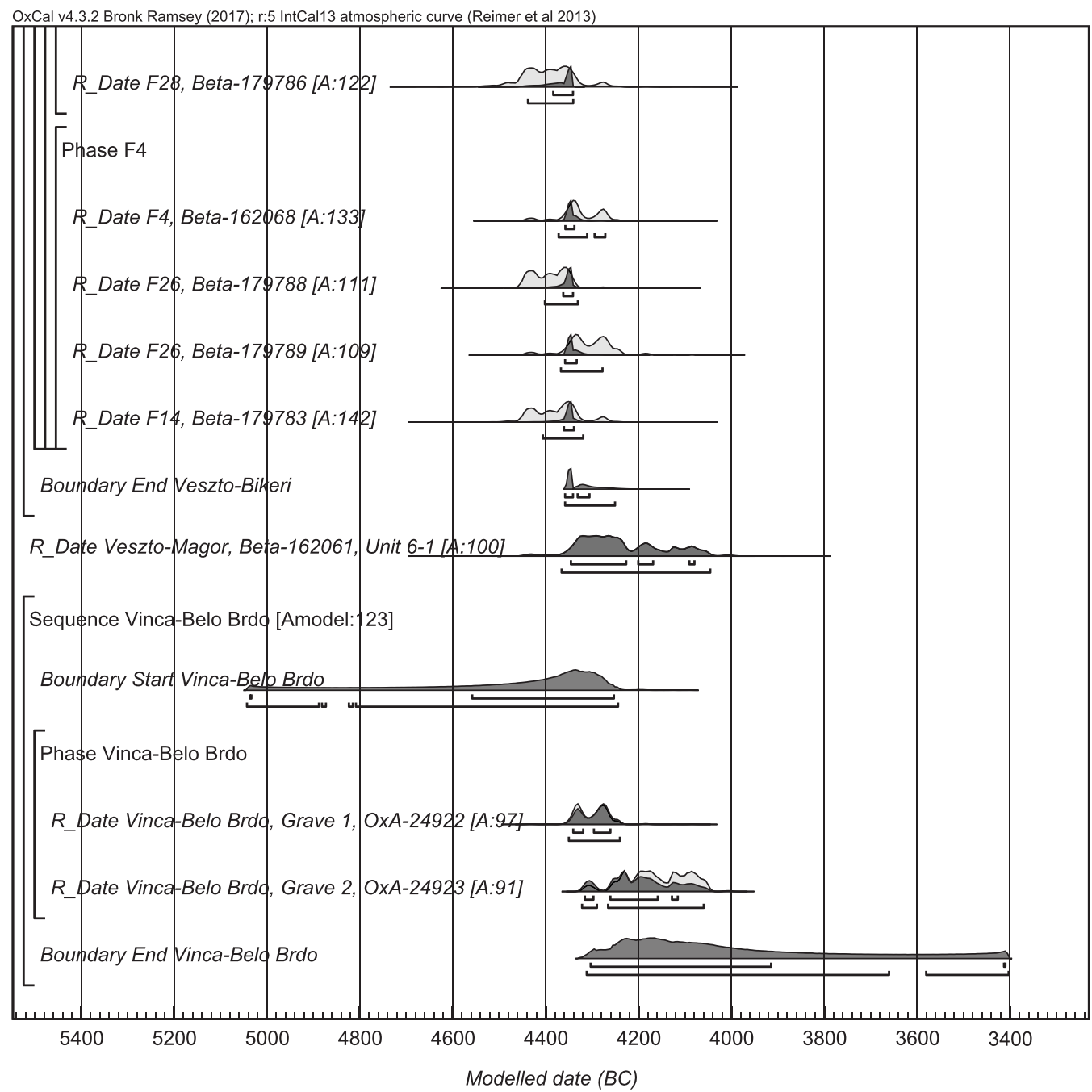




\section{APPENDIX 2}

Probability distributions of radiocarbon dates from ECA and MCA sites differentiating the archaeological features according to pottery styles. The square brackets on the left side along with the OxCal keywords exactly define the model.

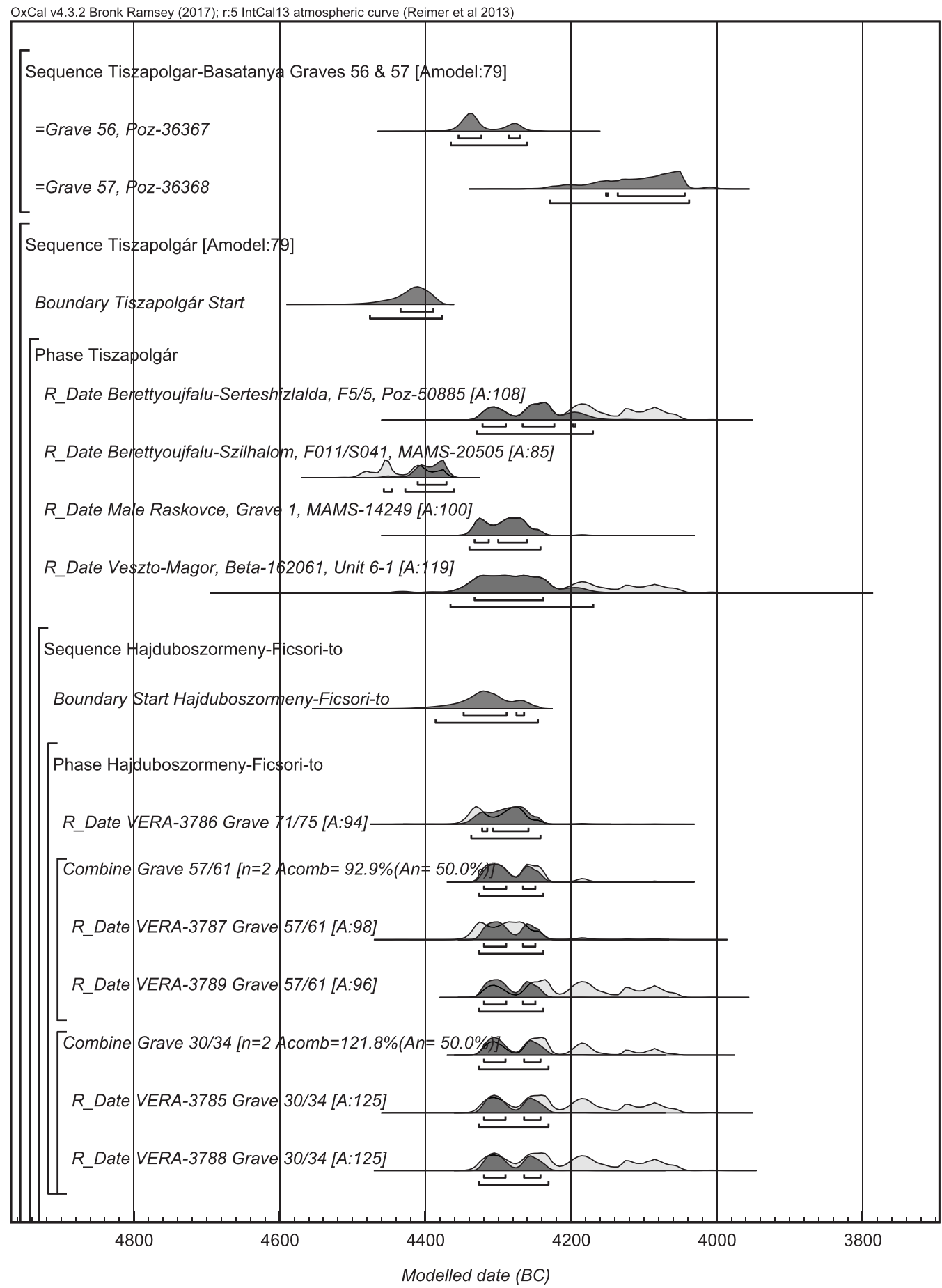




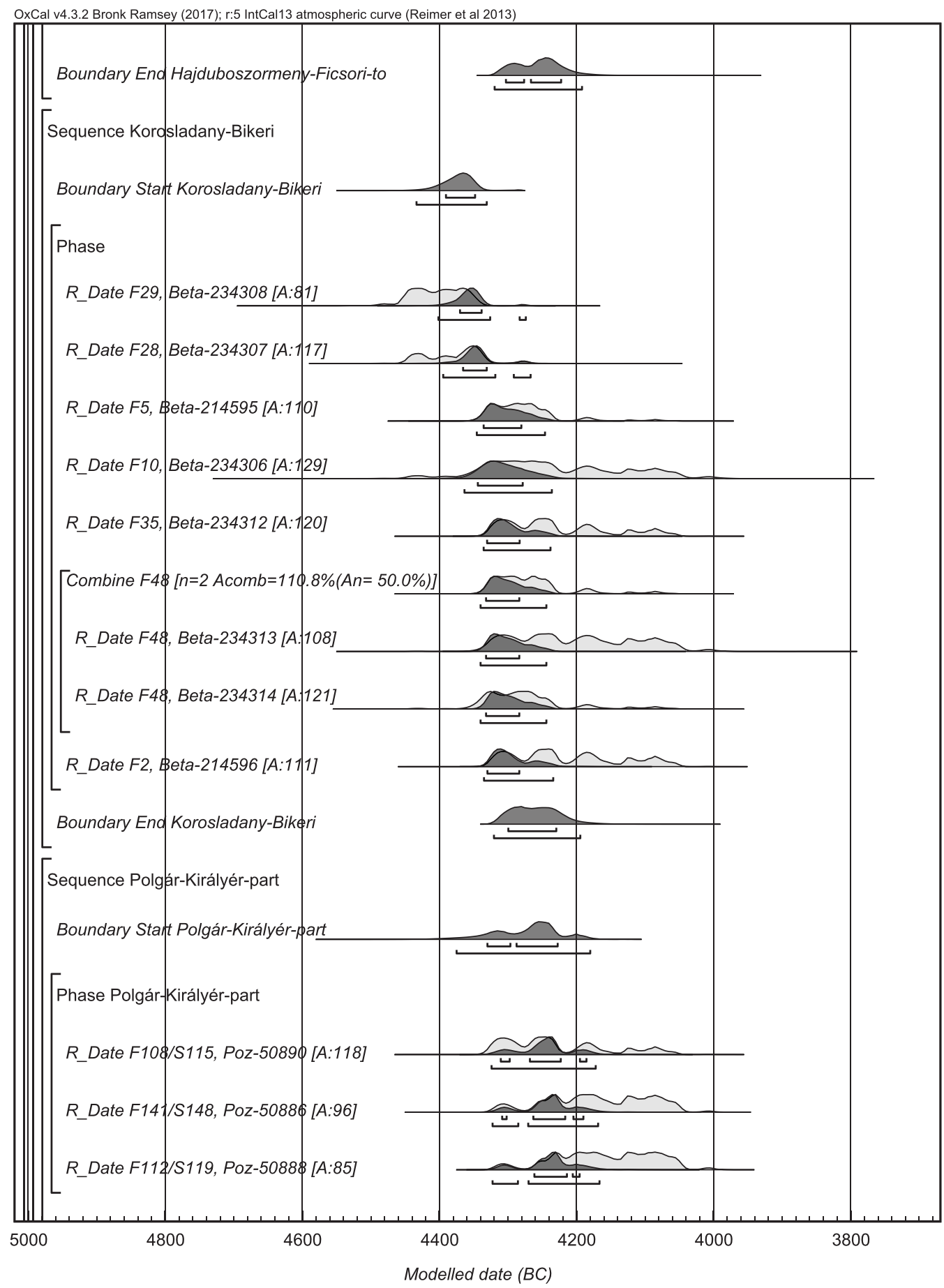


OxCal v4.3.2 Bronk Ramsey (2017); r:5 IntCal13 atmospheric curve (Reimer et al 2013)

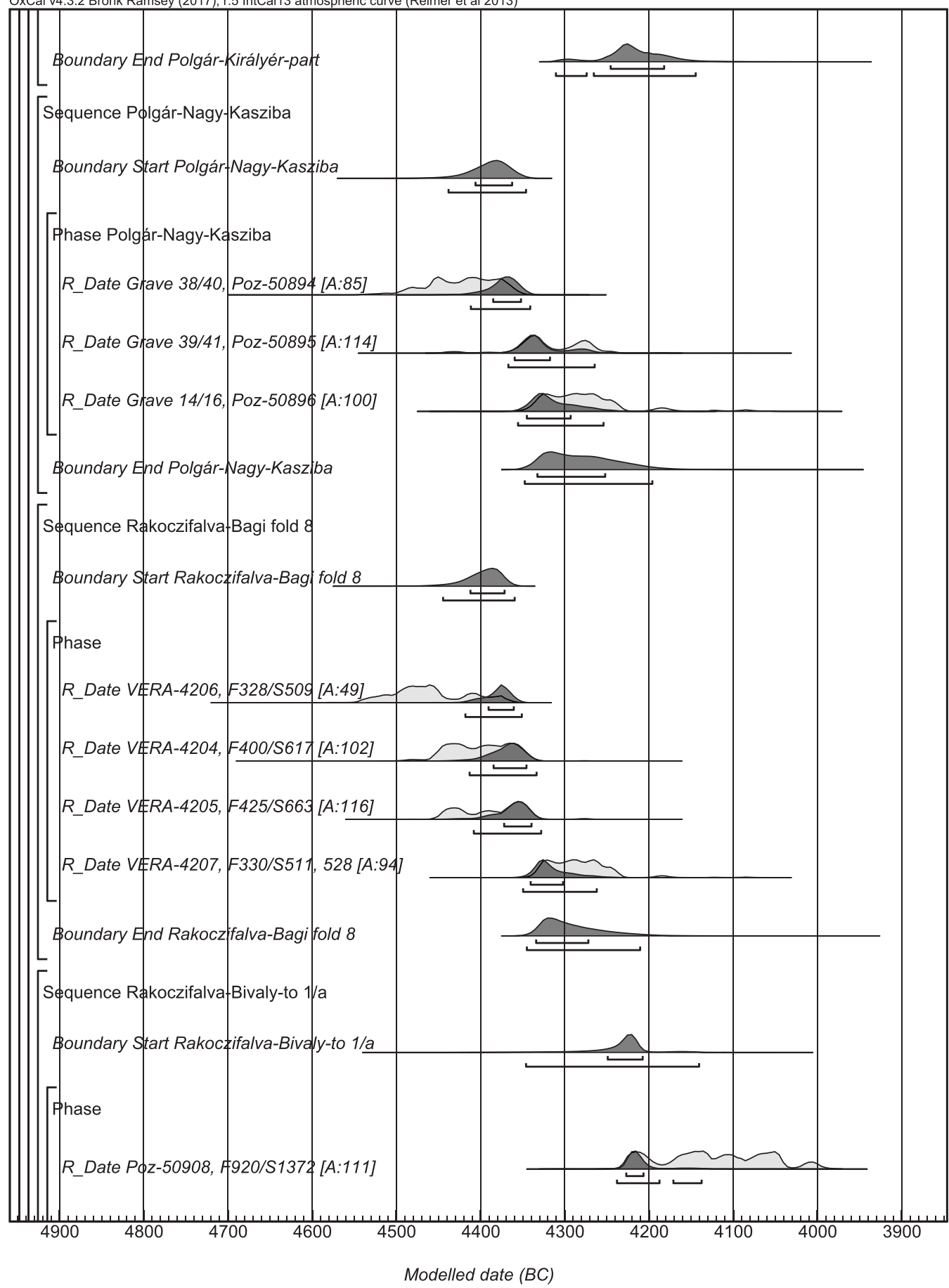


OxCal v4.3.2 Bronk Ramsey (2017); r:5 IntCal13 atmospheric curve (Reimer et al 2013)

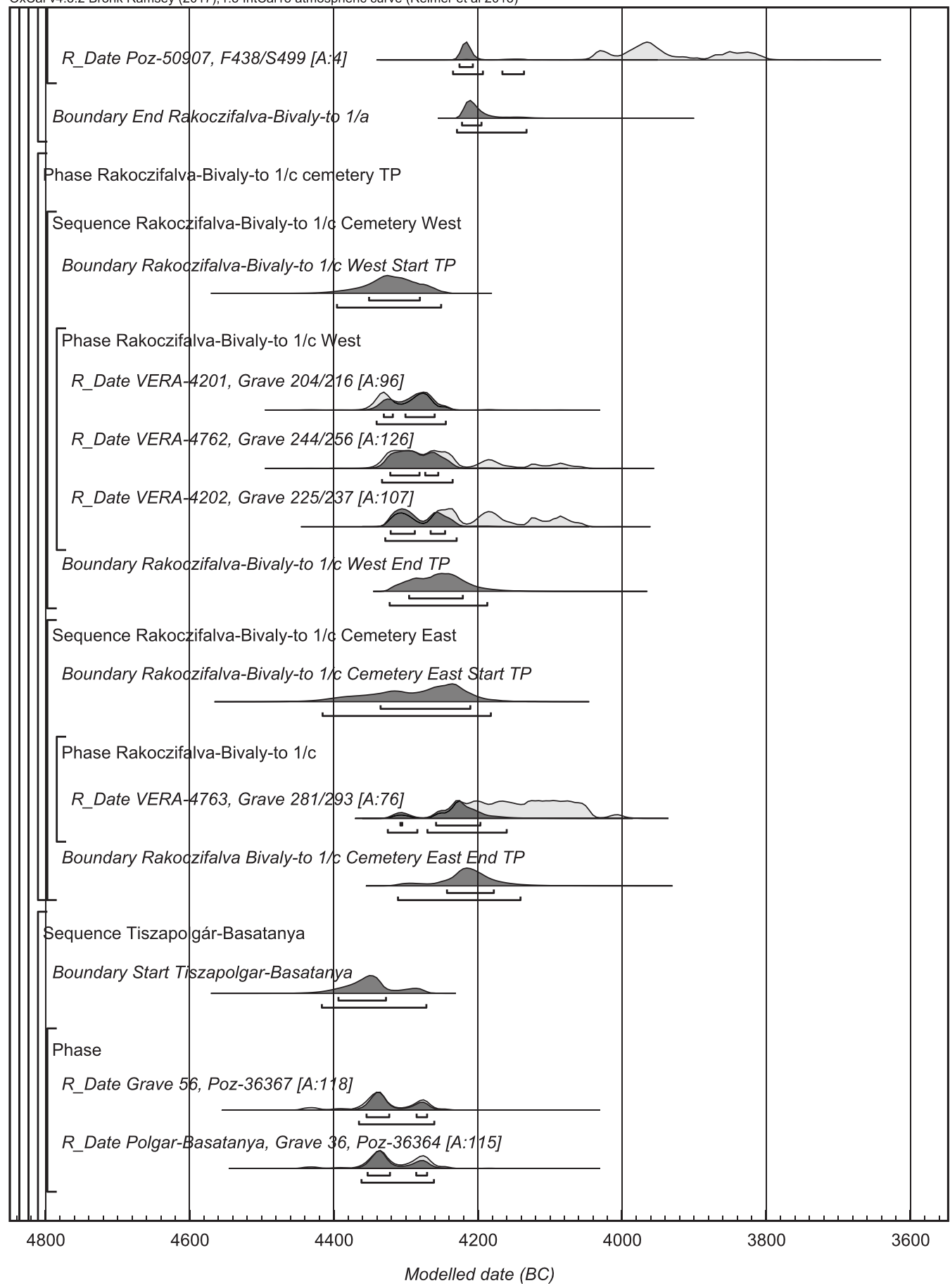


OxCal v4.3.2 Bronk Ramsey (2017); r:5 IntCal13 atmospheric curve (Reimer et al 2013)

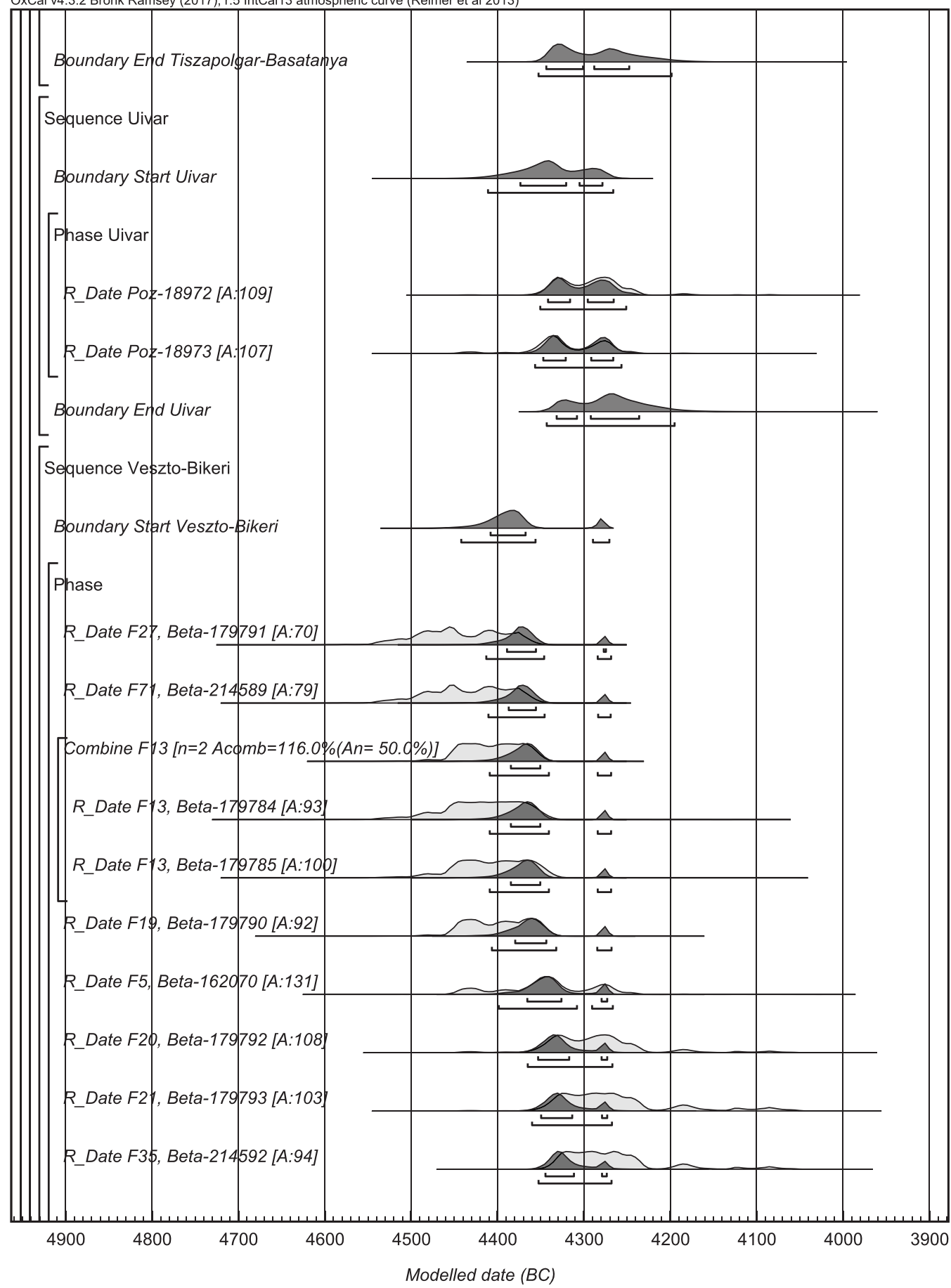


OxCal v4.3.2 Bronk Ramsey (2017); r:5 IntCal13 atmospheric curve (Reimer et al 2013)

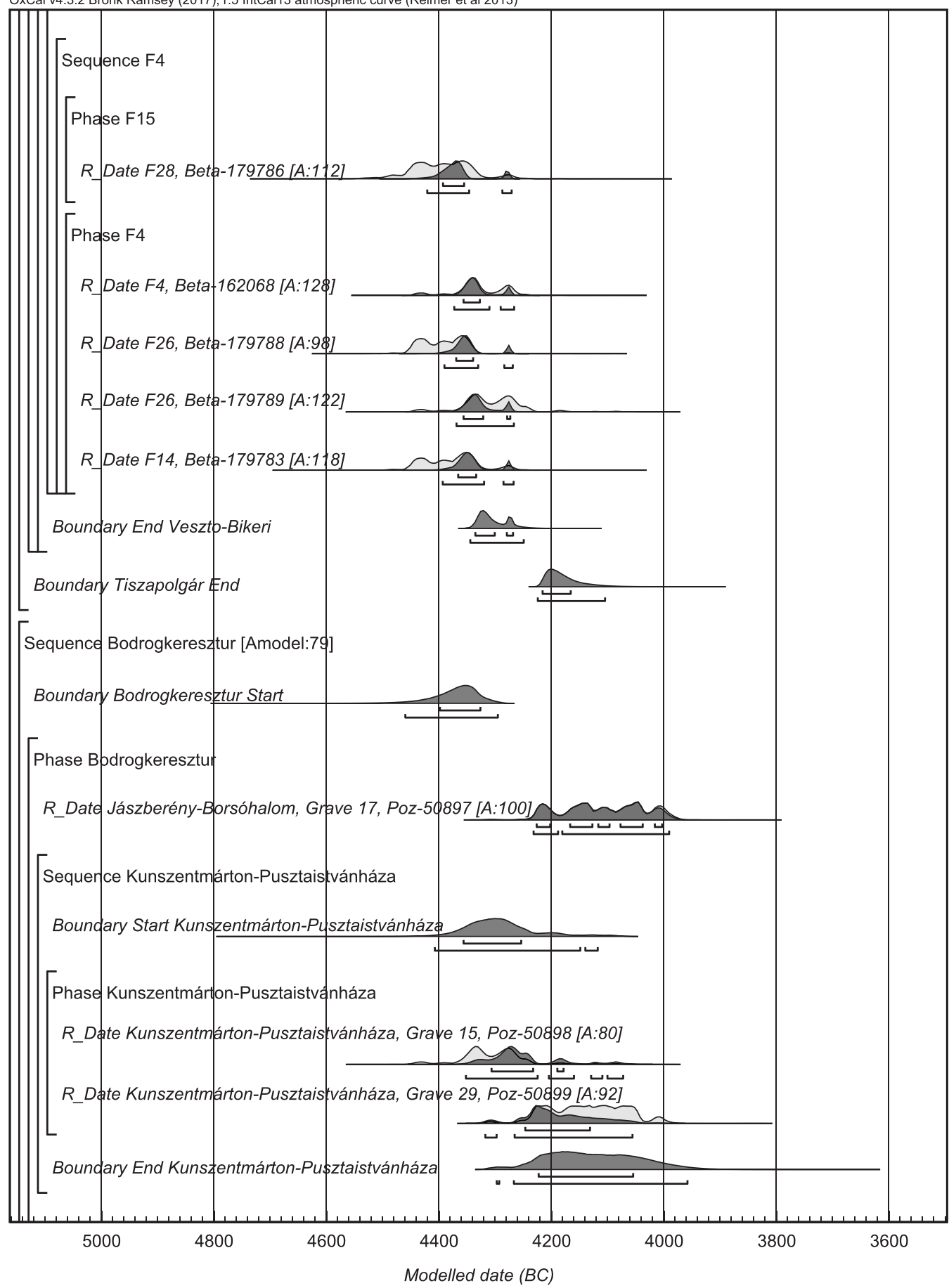


OxCal v4.3.2 Bronk Ramsey (2017); r:5 IntCal13 atmospheric curve (Reimer et al 2013)

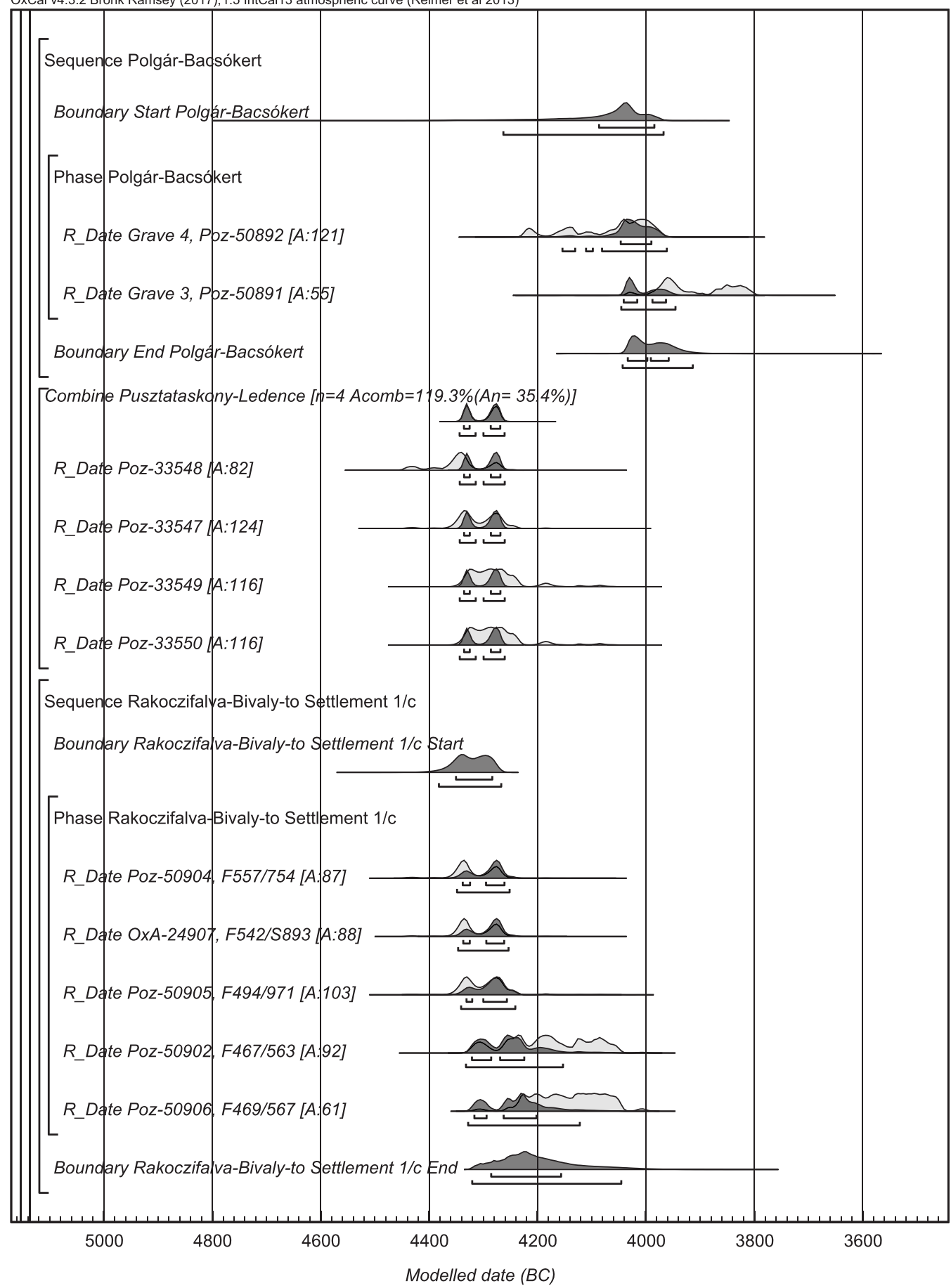




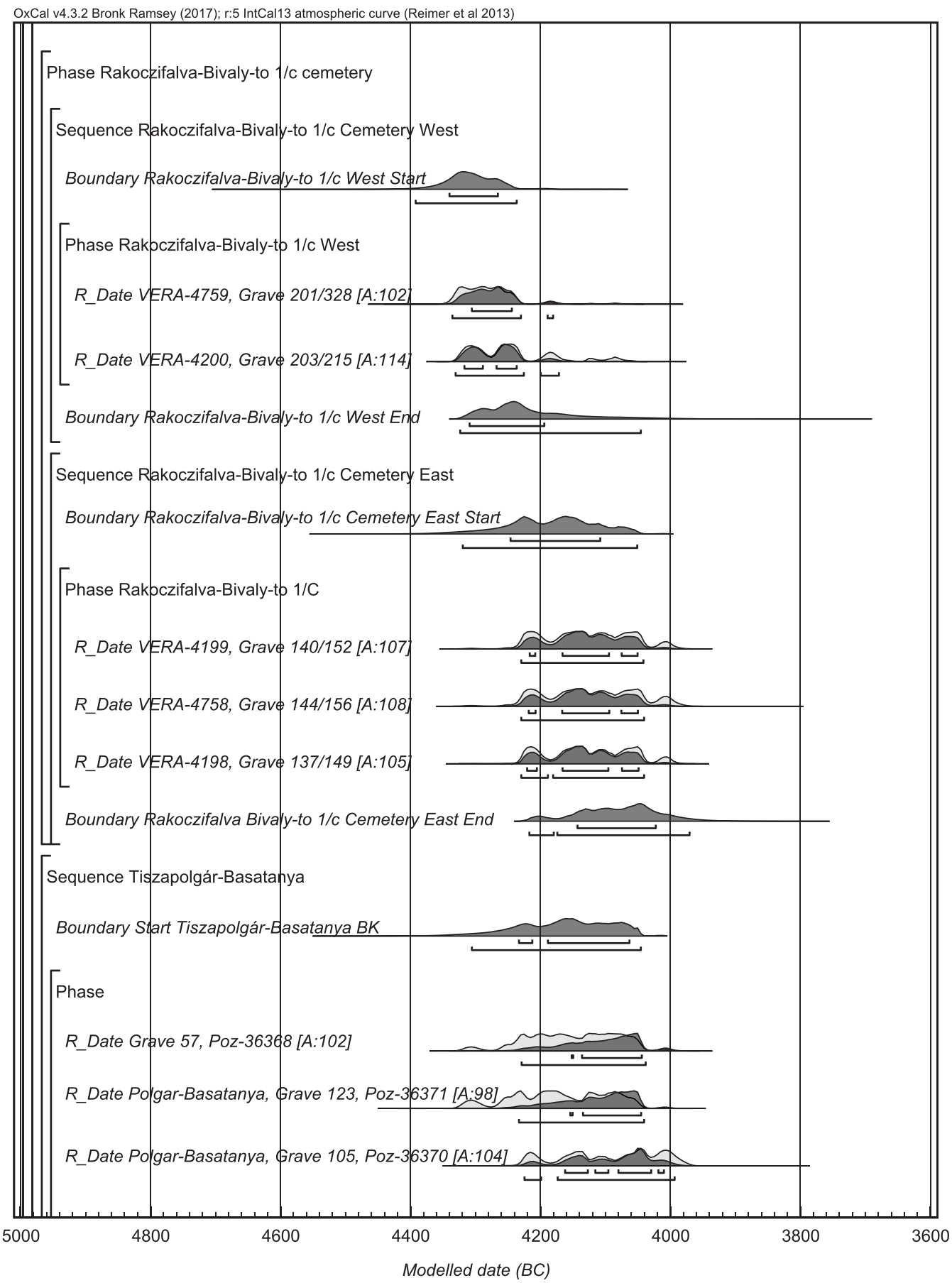




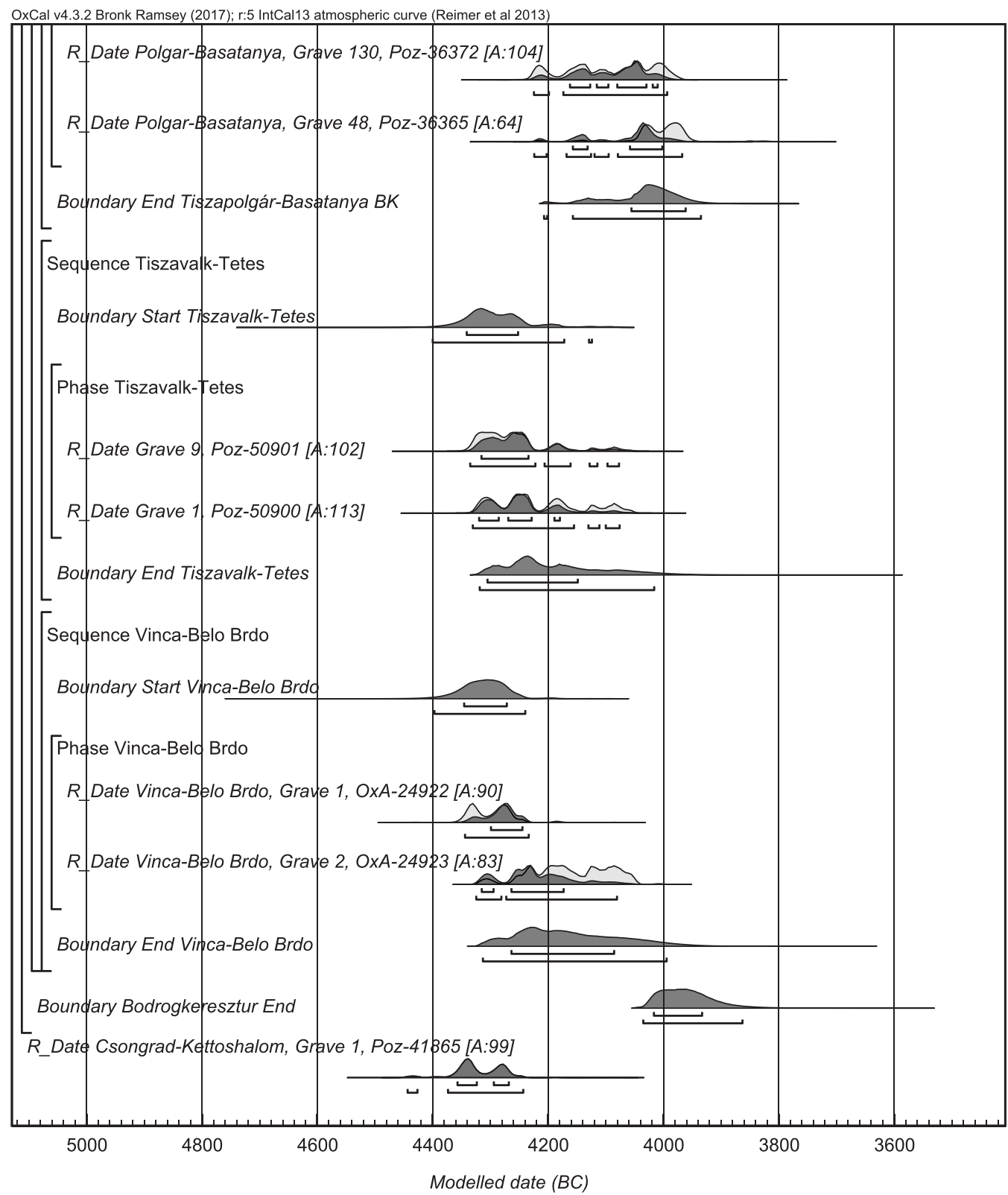

